ORNL/TM-2015/375

\title{
Design of Experiment for Irradiation of Welded Candidate Fe-Cr-Al Alloys
}

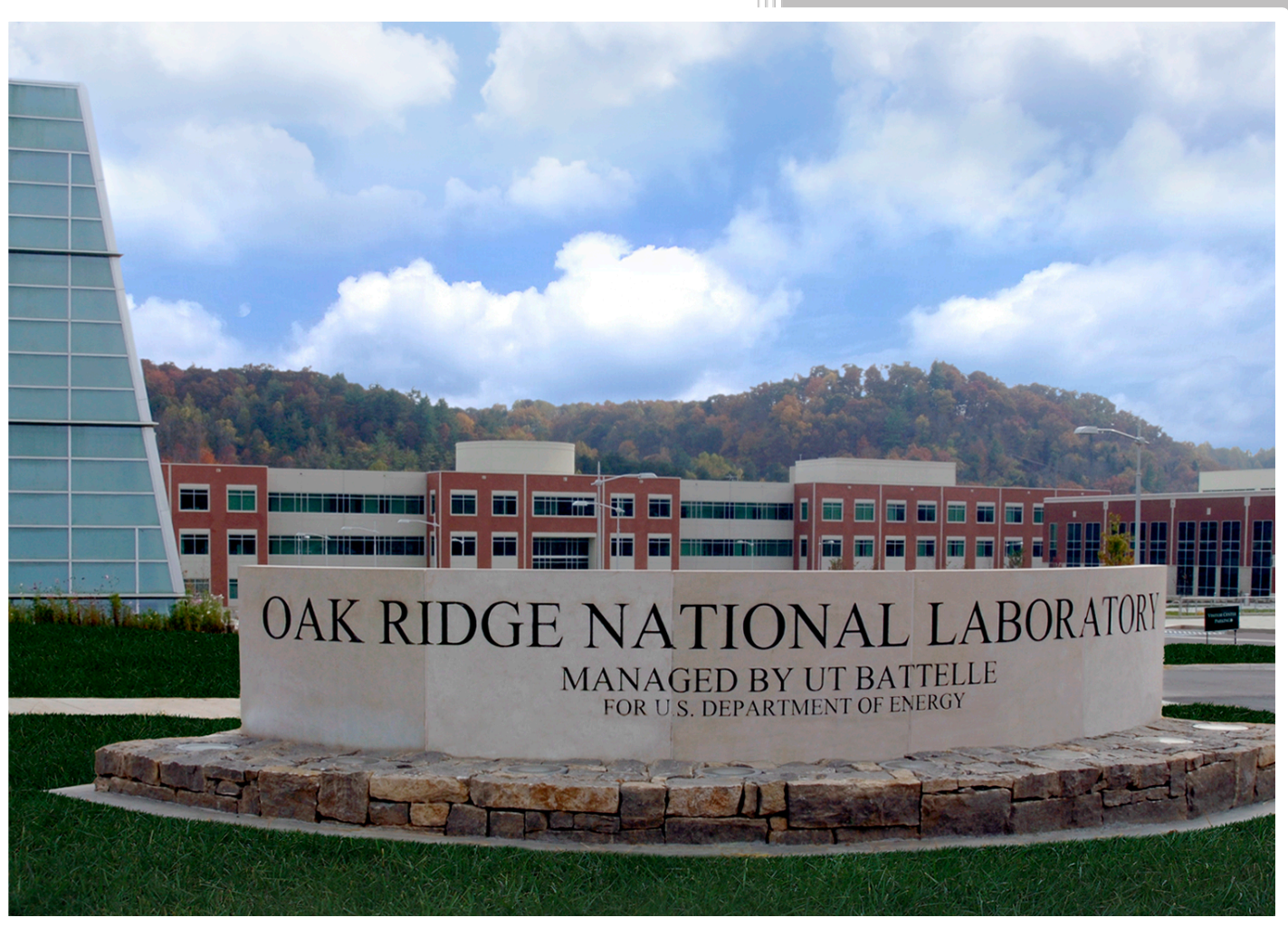

Approved for public release.

Kevin G. Field

Richard Howard

Yukinori Yamamoto

Distribution is unlimited.

July 31, 2015 


\section{DOCUMENT AVAILABILITY}

Reports produced after January 1, 1996, are generally available free via US Department of Energy (DOE) SciTech Connect.

Website http://www.osti.gov/scitech/

Reports produced before January 1, 1996, may be purchased by members of the public from the following source:

National Technical Information Service

5285 Port Royal Road

Springfield, VA 22161

Telephone 703-605-6000 (1-800-553-6847)

TDD 703-487-4639

Fax 703-605-6900

E-mail info@ntis.gov

Website http://www.ntis.gov/help/ordermethods.aspx

Reports are available to DOE employees, DOE contractors, Energy Technology Data Exchange representatives, and International Nuclear Information System representatives from the following source:

Office of Scientific and Technical Information

PO Box 62

Oak Ridge, TN 37831

Telephone 865-576-8401

Fax 865-576-5728

E-mail reports@osti.gov

Website http://www.osti.gov/contact.html

This report was prepared as an account of work sponsored by an agency of the United States Government. Neither the United States Government nor any agency thereof, nor any of their employees, makes any warranty, express or implied, or assumes any legal liability or responsibility for the accuracy, completeness, or usefulness of any information, apparatus, product, or process disclosed, or represents that its use would not infringe privately owned rights. Reference herein to any specific commercial product, process, or service by trade name, trademark, manufacturer, or otherwise, does not necessarily constitute or imply its endorsement, recommendation, or favoring by the United States Government or any agency thereof. The views and opinions of authors expressed herein do not necessarily state or reflect those of the United States Government or any agency thereof. 
Nuclear Energy Enabling Technologies (NEET): Reactor Materials Effort

\title{
Design of Experiment for Irradiation of Welded Candidate Fe-Cr-Al Alloys
}

\author{
Kevin G. Field, Richard Howard, Yukinori Yamamoto
}

Date Published: July $31^{\text {st }}, 2015$

\author{
Prepared by \\ OAK RIDGE NATIONAL LABORATORY \\ Oak Ridge, Tennessee 37831-6283 \\ managed by \\ UT-BATTELLE, LLC \\ for the \\ US DEPARTMENT OF ENERGY \\ under contract DE-AC05-00OR22725
}





\section{CONTENTS}

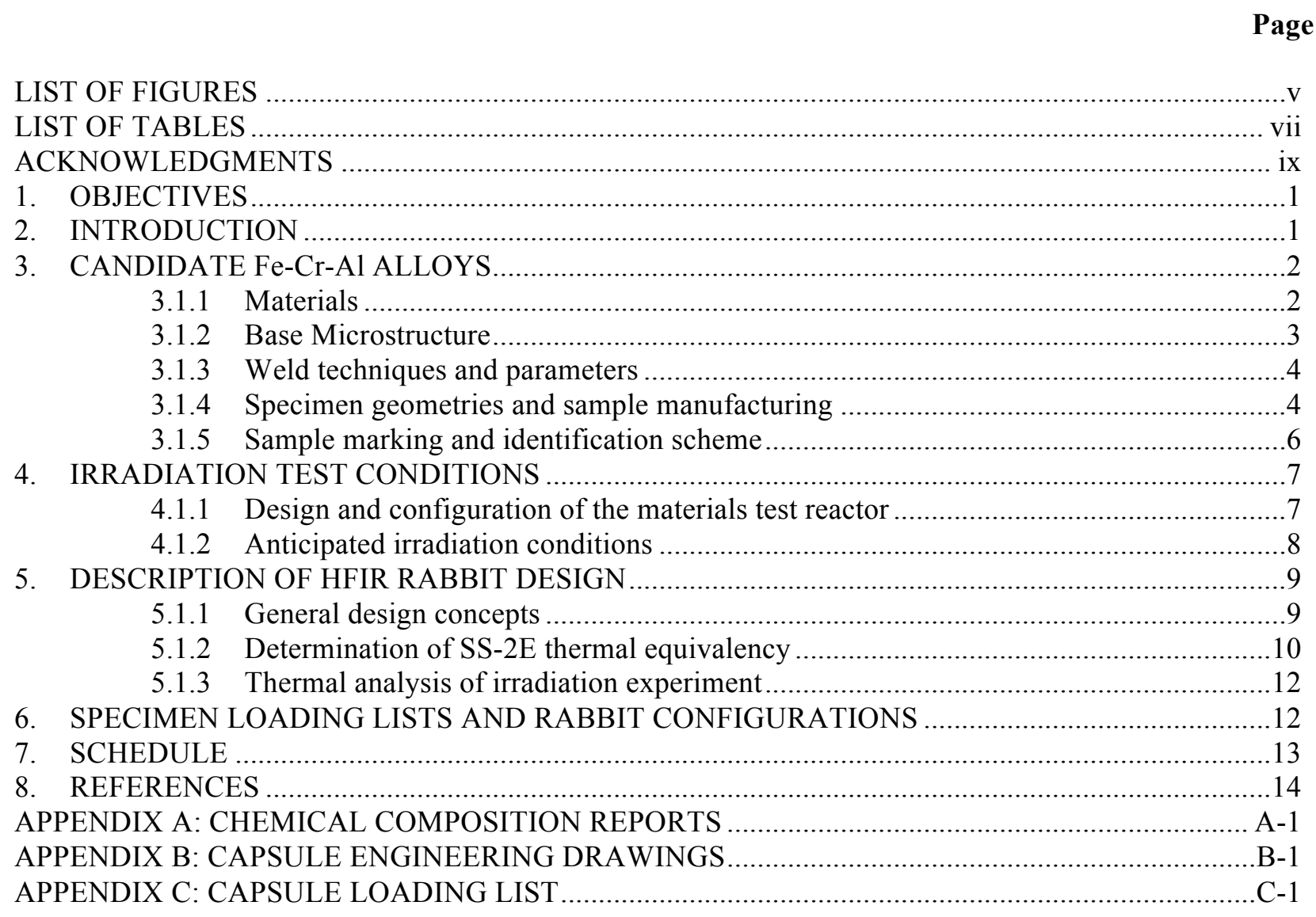





\section{LIST OF FIGURES}

Figure $\quad$ Page

Figure 1: Optical micrographs of candidate $\mathrm{Fe}-\mathrm{Cr}-\mathrm{Al}$ alloys for welding and irradiation testing; (a) C35M, (b) C36M, (c) C37M, (d) C35MN, (e) C35M01TC, (f) C35M03TC, and (g) C35M10TC. Rolling direction is left to right in all images.

Figure 2: Image of cross-welds performed using laser welding techniques on the C37M alloy; (a) as imaged, (b) with overlays of SS-J2 and SS-2E sample geometries to show where samples were fabricated from in Section 3.1.4.

Figure 3: Simplified schematic of the tensile specimen geometries for weld and irradiation testing. Figure not to scale.

Figure 4: Image of welded C37M specimens prior to surface machining. Red dots denote specimens with fusion zones far from the center of the gauge region of the specimen.

Figure 5: Image of laser engraving positions on sample specimens; (a) position on SS-J2 sample and (b) position on SS-2E sample.

Figure 6: Flux trap irradiation locations in the HFIR.

Figure 7: Estimated fast neutron flux at positions within the HFIR. PTP: peripheral target position; TRRH: target rod rabbit holder position; HT: hydraulic tube position. .................................. 8

Figure 8: Finalized HFIR rabbit design for irradiation of welded and non-welded tensile specimens. ......10

Figure 9. Average Specimen Temperature comparison for the different loading configurations $\left(550^{\circ} \mathrm{C}\right.$ case $)$

Figure 10. Temperature contour plot comparison between the SS-J2 (only) configuration and the general configuration. 



\section{LIST OF TABLES}

\section{Table}

Page

Table 1: Identified Fe-Cr-Al alloys fabricated for testing to determine weldability and radiation tolerance. .2

Table 2: Specimen ID marking for specimens for weld and irradiation testing ......................................6

Table 3: Position of capsules for irradiation within the HFIR. Nominal dose (dpa) is calculated

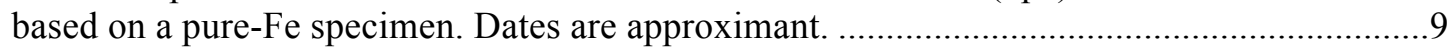

Table 4: Thermal analysis conditions for a mixed SS-2E and SS-J2 tensile specimens' capsule. ..............12

Table 5: Single rabbit loading list by alloy type, specimen type, and configuration. Alloys FCAODS and C06M are Fe-Cr-Al alloys currently of interest in other irradiation programs. .......13

Table 6: Anticipated irradiation campaign schedule. Dates are approximant. 



\section{ACKNOWLEDGMENTS}

This research was sponsored by the U.S. Department of Energy, Office of Nuclear Energy, for the Nuclear Energy Enabling Technologies (NEET) program for the Reactor Materials effort. 


\section{OBJECTIVES}

The objective of the irradiation campaign described within is to provide critical data on the radiation response of candidate $\mathrm{Fe}-\mathrm{Cr}-\mathrm{Al}$ alloys designed to have enhanced weldability and radiation tolerance. This objective will be met by using a specialized irradiation capsule to be inserted into Oak Ridge National Laboratory's High Flux Isotope Reactor (HFIR) followed by extensive post irradiation examination (PIE) including mechanical testing and microstructural characterization. Several different irradiation temperatures and doses will be investigated to establish temperature/dose relationships on specific radiation-induced and/or radiation-enhanced mechanisms within the candidate $\mathrm{Fe}-\mathrm{Cr}-\mathrm{Al}$ alloys. Data and analysis as the result of these efforts will enable informed decisions on the future use of $\mathrm{Fe}-\mathrm{Cr}$ $\mathrm{Al}$ alloys for a wide range of nuclear power generation applications including fission and fusion based reactor applications.

\section{INTRODUCTION}

Fe-Cr-Al alloys are an attractive class of materials for nuclear power production applications due to their excellent environmental compatibility including aqueous corrosion, $\mathrm{Pb}$-Li compatibility, and high temperature steam oxidation $[1,2]$. Furthermore, Fe-Cr-Al alloys have seen use in other energy generation and industrial applications including the fossil fuel and automotive industry. The use within these industries provides a foundation in which to establish materials development efforts of $\mathrm{Fe}-\mathrm{Cr}-\mathrm{Al}$ alloys for nuclear environments. One issue of primary concern for nuclear applications is the ability to successfully join parts through fusion-based welding and/or solid-state welding technologies. Research in non-nuclear industries indicates that $\mathrm{Fe}-\mathrm{Cr}$-Al alloys are susceptible to cracking using fusion-based welded technologies [3-5]. In particular, studies such as the one conducted by Dupont et al. indicate that hydrogen impurities can lead to significant cracking in specific Fe-Cr-Al alloy compositions [6]. Such cracking during joining would limit the application of $\mathrm{Fe}-\mathrm{Cr}-\mathrm{Al}$ alloys for nuclear applications.

Another mater of concern for joining of $\mathrm{Fe}-\mathrm{Cr}-\mathrm{Al}$ alloys is the radiation tolerance in typical radiation environments for nuclear power production. Fusion based welding technologies can lead to microstructures that are vastly different from the microstructures seen in the base material. It is well known that microstructural features such as grain size, dislocation density, and precipitate density/size can greatly impact the radiation tolerance of a material [7]. The loss of controlled microstructure through fusion-based welding could compound with the detrimental formation of the Cr-rich $\alpha$ ' phase that has been shown to occur in specific Fe-Cr-Al alloy compositions during neutron irradiation [8]. Such limited radiation tolerance within the fusion zone of a weldment could lead to significant radiation-induced hardening and embrittlement leading to possible cracking of an in-service part. Embrittlement and cracking of a weldment during operation in a commercial nuclear power plant is unacceptable.

Currently, no systematic investigations have been conducted to assess the weldability and radiation tolerance of controlled fusion welds in the Fe-Cr-Al alloy class. Such lack of data and analysis limits the ability to draw conclusions on the performance of welded $\mathrm{Fe}-\mathrm{Cr}-\mathrm{Al}$ alloys for nuclear power generation applications. To fill this knowledge gap and establish baseline properties of welded $\mathrm{Fe}-\mathrm{Cr}$-Al alloys for nuclear applications, a research and development program centralized on the use of candidate $\mathrm{Fe}-\mathrm{Cr}-\mathrm{Al}$ alloys, fusion based welding techniques, and irradiation campaigns using the High Flux Isotope Reactor (HFIR) has been established.

The program is centralized on two specific mitigation strategies for joining and/or radiation-induced hardening and embrittlement of Fe-Cr-Al weldments. The first is the use of hydrogen trapping sites to limit cracking resulting from the fusion-based welding process. The second is the use of $\mathrm{Fe}-\mathrm{Cr}-\mathrm{Al}$ alloys with $\mathrm{Al}$ contents above $5 \mathrm{wt}$.\% to limit the precipitation of the Cr-rich $\alpha^{\prime}$ phase during service. Both of 
these mitigation strategies could have compounding effects leading to significantly reduced chances of failure of a Fe-Cr-Al made part during service due to material based issues. Both of these candidate Fe$\mathrm{Cr}-\mathrm{Al}$ alloy types have been fabricated as part of the program with highlights on the processing routes reported previously [9].

To investigate the capability of these candidate Fe-Cr-Al alloys, controlled laser-based welding has been conducted. These weldments are currently undergoing extensive microstructural characterization to determine the weldability of the candidate alloys. Of the upmost importance, is the investigation on the radiation tolerance of both welded and non-welded variants of the candidate $\mathrm{Fe}-\mathrm{Cr}$-Al alloys. Therefore, a large-scale irradiation campaign centralized on evaluating the radiation tolerance of the alloys at varying conditions has been conceptualized, designed, and fabricated. The following report highlights the activities centered on the alloys for investigation, the design of experiment, and capsule fabrication for the HFIR-based irradiation program.

\section{CANDIDATE Fe-Cr-Al ALLOYS}

\subsubsection{Materials}

The alloys for investigation are those fabricated and reported on previously [9]. To summarize, seven Fe$\mathrm{Cr}-\mathrm{Al}$ alloy variants have been fabricated from a base Fe-13Cr-5Al-2Mo-0.2Si-0.05Y alloy. The nominal compositions of these alloys and their designations can be found in Table 1. The compositions determined by an outside vendor are provided in Appendix A for reference. Table 1 can be broken into three distinct sub-groups, the first is Fe-Cr-Al alloys with high-Al additions (designated C36M and C37M), a Fe-Cr-Al alloy with Laves phase dispersions (designated as $\mathrm{C} 35 \mathrm{MN}$ ), and three $\mathrm{Fe}-\mathrm{Cr}-\mathrm{Al}$ alloys with $\mathrm{TiC}$ precipitate dispersions (designated as C35M01TC, C35M03TC, and C35M10TC) which are all variants from the base $\mathrm{C} 35 \mathrm{M}$ alloy. The addition of higher-Al contents is suspected to push the phase boundary for Cr-rich $\alpha$ ' formation based on the results of Kobayashi and Takasugi [10] thereby reducing it's propensity to precipitate under irradiation. The dispersions of Laves and $\mathrm{TiC}$ precipitates are hypothesized to act as permanent hydrogen trapping sites thereby reducing the diffusible hydrogen, which can lead to embrittlement and/or cracking of the alloys during welding.

Table 1: Identified Fe-Cr-Al alloys fabricated for testing to determine weldability and radiation tolerance.

\begin{tabular}{|c|c|c|c|c|c|c|c|c|c|}
\hline \multirow{2}{*}{ Name } & \multirow{2}{*}{ Heat ID } & \multicolumn{7}{|c|}{ Nominal Compositions (wt. \%) } \\
\cline { 3 - 10 } & & Fe & Cr & Al & Mo & Nb & Si & Y & TiC \\
\hline \hline C35M & C35M3 & Bal. & 13 & 5.2 & 2 & - & 0.2 & 0.05 & - \\
\hline C36M & C36M2 & Bal. & 13 & 6 & 2 & - & 0.2 & 0.05 & - \\
\hline C37M & C37M & Bal. & 13 & 7 & 2 & - & 0.2 & 0.05 & - \\
\hline C35MN & C35MN6B & Bal. & 13 & 5.2 & 2 & 1 & 0.2 & 0.05 & - \\
\hline C35M01TC & $\# 20766$ & Bal. & 13 & 5.2 & 2 & - & 0.2 & 0.05 & 0.1 \\
\hline C35M03TC & $\# 20767$ & Bal. & 13 & 5.2 & 2 & - & 0.2 & 0.05 & 0.3 \\
\hline C35M10TC & $\# 20768$ & Bal. & 13 & 5.2 & 2 & - & 0.2 & 0.05 & 1.0 \\
\hline
\end{tabular}

Two primary processing routes to produce these alloys were taken: vacuum induction melting (VIM) or arc melting with drop-casting. VIM production resulted in $\sim 18 \mathrm{~kg}$ heats while arc melts were on the laboratory scale with weights on the order of $1 \mathrm{~kg}$. Thermo-mechanical treatments (TMT) were applied to produce optimized microstructures. The specifics of the processing routes for each of the three sub-groups of $\mathrm{Fe}-\mathrm{Cr}-\mathrm{Al}$ alloys can be found in previous reports [9]. 


\subsubsection{Base Microstructure}

All alloys slated for irradiation exhibit a fully-ferritic microstructure with varying grain sizes and secondary phase inclusions. The high-Al variants have elongated grains along the rolling direction together with partially recrystallized grains with grain sizes less than $5 \mu \mathrm{m}$. The Laves phase and TiC precipitate dispersion alloys are macroscopically similar to that of the high-Al variants but exhibited discrete secondary phase(s) dispersions in the matrix under microstructural examination. The C35MN alloy with Laves phase precipitate dispersions consisted of a sub-grain structure with fine Laves phase precipitate distribution while the C35M01TC, C35M03TC, and C35M10TC alloys had TiC precipitates with size of less than $5 \mu \mathrm{m}$ uniformly dispersed in the fully recrystallized matrix consisting of $\sim 10 \mu \mathrm{m}$ size grains. Representative micrographs of each alloy are provided in Figure 1.

(a)

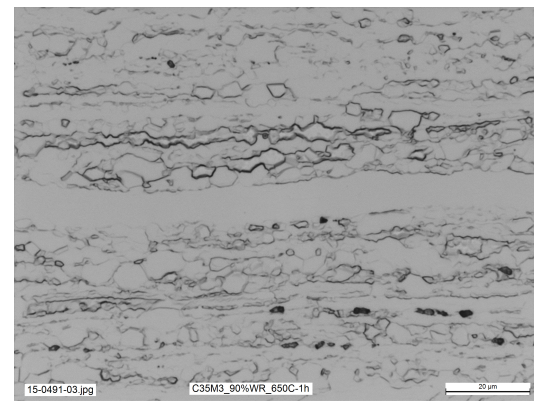

(c)

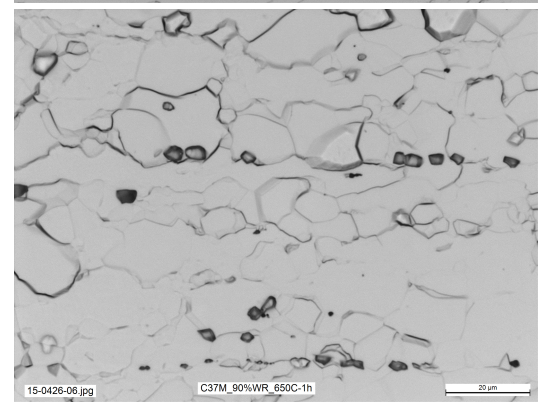

(e)

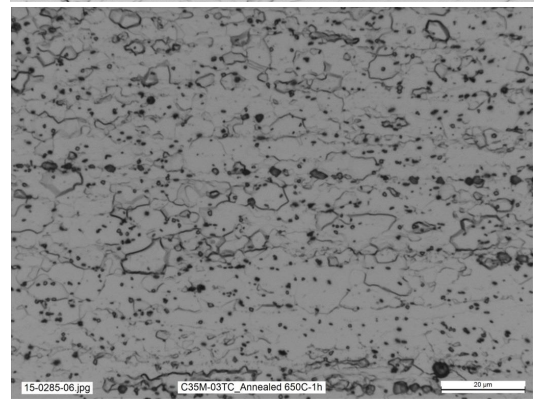

(g)

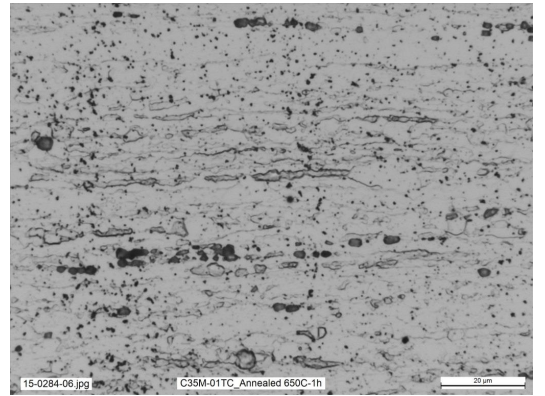

(b)

(d)

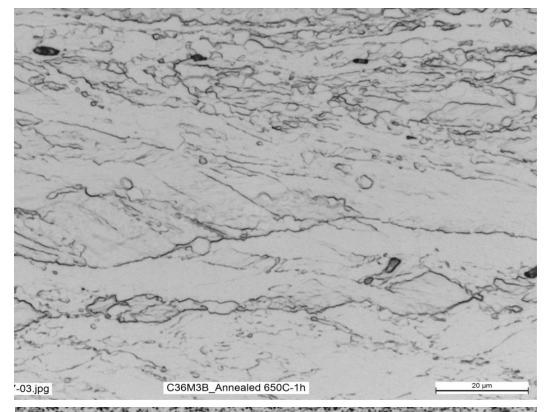

(f)

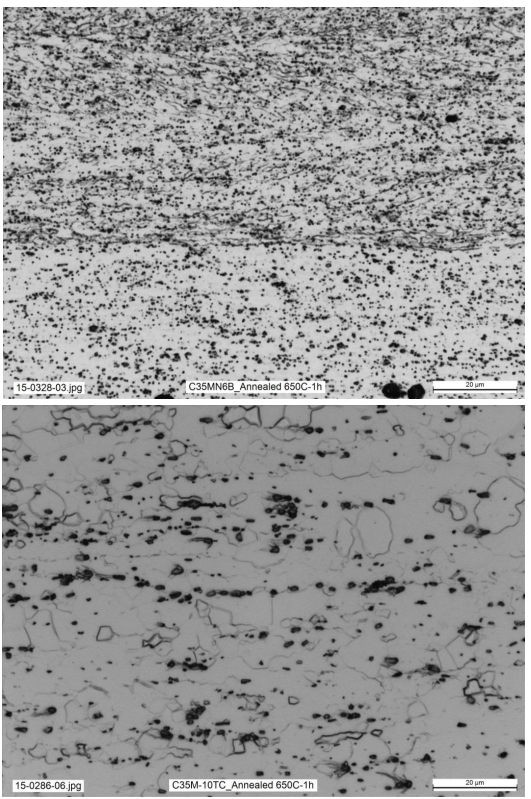

Figure 1: Optical micrographs of candidate $\mathrm{Fe}-\mathrm{Cr}-\mathrm{Al}$ alloys for welding and irradiation testing; (a) C35M, (b) C36M, (c) C37M, (d) C35MN, (e) C35M01TC, (f) C35M03TC, and (g) C35M10TC. Rolling direction is left to right in all images. 


\subsubsection{Weld techniques and parameters}

A sub-section of the as-received material from each alloy was used to conduct autogenous, bead-on-plate welding along the traverse direction. A pulsed laser-welding machine was used to perform the welding. No pre-heating of the specimens was used. Welding parameters were optimized to generate full penetration welds: $7 \mathrm{~ms}$ pulse length, 7 pulses $/ \mathrm{s}$ and $2.12 \mathrm{~mm} / \mathrm{s}$ welding speed. Lamp energy was maintained to have a nominal average of 100 Watts. These parameters were applied to every sample except the C35MN sample. The C35MN feedstock was thicker than the other alloys resulting in the need for higher laser welding settings. All welding was conducted in an inert argon cover gas. Unlike previous welding trials [9], care was taken to limit the depression in the fusion zone that is a result of low cooling rates. By increasing the cooling rates, the objects remained relatively flat and with limited variation when viewed in cross-section. Figure 2 shows an example of the resulting welds used for specimen fabrication. Figure $2 b$ shows the extraction map for both SS-J2 and SS-2E sample geometries. Staggering of the different specimen types was done to limit overlapping of the heat-affected zone (HAZ) in SS-2E specimens as HAZs extended past the tensile heads of the SS-2E specimens. More details on the specimen geometries are provided in the following section. Similar lay-up configurations to the one shown in Figure 2 were used for all alloys of interest.

(a)

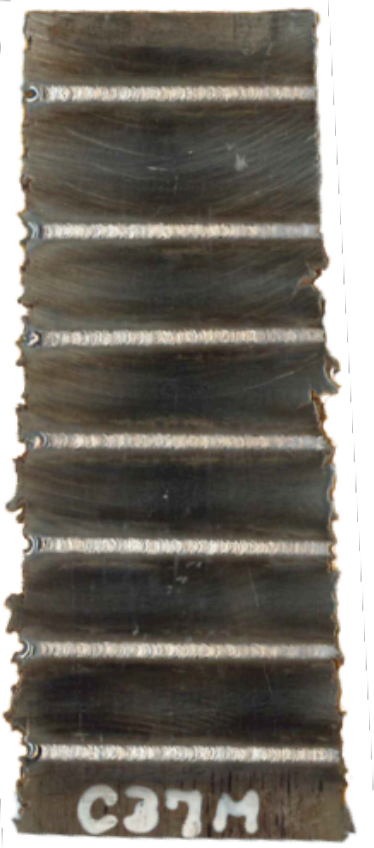

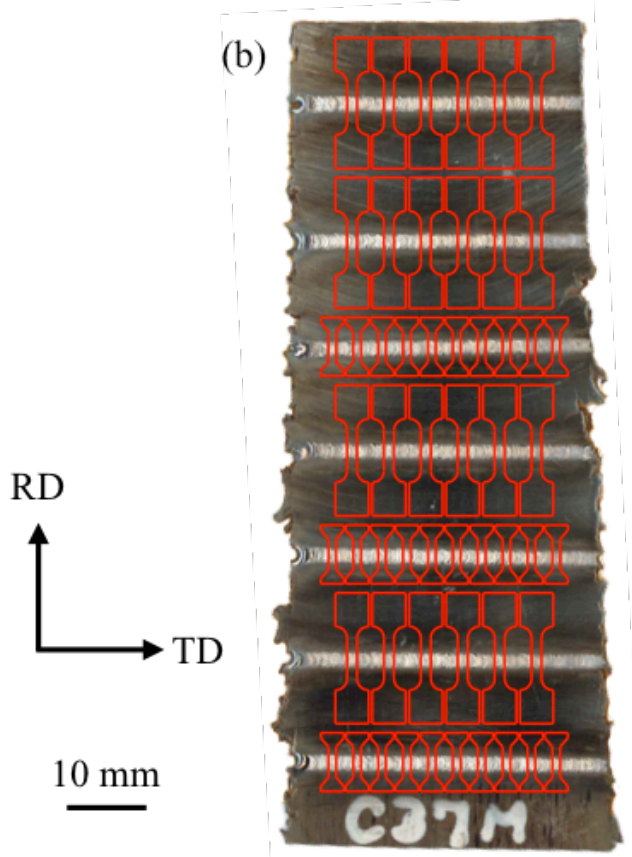

Figure 2: Image of cross-welds performed using laser welding techniques on the C37M alloy; (a) as imaged, (b) with overlays of SS-J2 and SS-2E sample geometries to show where samples were fabricated from in Section 3.1.4.

\subsubsection{Specimen geometries and sample manufacturing}

For welding and irradiation testing, two tensile specimen geometries will be used to determine mechanical properties. Both configurations, the SS-2E and the SS-J2 configurations, are shown in Figure 3. Appendix B provides the detailed engineering drawings for both specimen configurations. The SS-J2 specimen was selected as the baseline tensile specimen geometry due to the geometry being extensively used for irradiation campaigns within the HFIR. This will allow for comparison to the other nuclear materials such as $\mathrm{Fe}-\mathrm{Cr}$ and $\mathrm{Fe}-\mathrm{Cr}-\mathrm{Ni}$ based alloys. Furthermore, the sheet type dog-bone configuration 
allows for efficient stacking within the irradiation capsule geometry and provides effective heat transfer across the stacked faces during irradiation. Here, SS-J2 specimens without pinholes are used. The elimination of the pinhole provides more material for materials characterization sample preparation such as focused ion beam (FIB) preparation and allows for easier loading into the tensile test frame using typical hot cell manipulator configurations. The SS-2E configuration was selected as the ultra-miniature tensile specimen of choice for this campaign [9]. This geometry will significantly reduce the sample activity thereby providing out-of-cell tensile testing when irradiated to low doses $(<10-20 \mathrm{dpa})$. The geometry has been found to accurately mimic the mechanical performance of the SS-J2 configuration when used within the same testing frame and material class [9]. Another key advantage is significantly more specimens can be irradiated at a single time within the same volume occupied by the SS-J2 specimen.
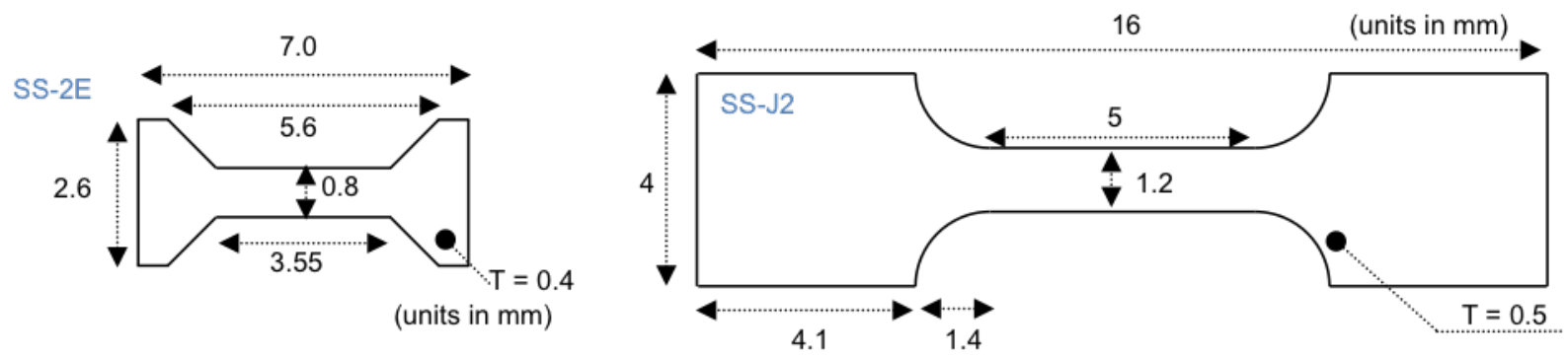

Figure 3: Simplified schematic of the tensile specimen geometries for weld and irradiation testing. Figure not to scale.

A single outside vendor which met the quality requirements of the program manufactured all samples for irradiation. Samples were machined using an electric discharge machine (EDM) from flat sheet product provided to the vendor. Care was taken during machining of the SS-2E specimen geometry as the small features prevented reworking of burned faces from the EDM machine. Hence, a multi-pass technique with gradually lower settings was used to limit the amount (or depth) of the EDM burn layer on each specimen. For larger features, the EDM burn layers were removed to limit any possible fabricationinduced artifacts into the specimens. For welded specimens, care was taken to align the fusion zone of a weld within the center of the gauge region of each tensile specimen. Here, the top-weld was centered on the gauge; some deviation on the bottom-weld from center is anticipated. Due to the thickness of the specimens, it was recognized that both the top and bottom of each specimen needed to be machined to provide specimen thicknesses within the tolerances of the drawings provided in Appendix B. The resulting machining operation would mean losing visual tracking of the fusion zone within the gauge region. To assist with post-fabrication mechanical testing either in the as-received state or irradiated state, each individual sample was imaged prior to surface machining. An example of the C37M batch of welded specimens showing the fusion zone location of each specimen can be found in Figure 4.

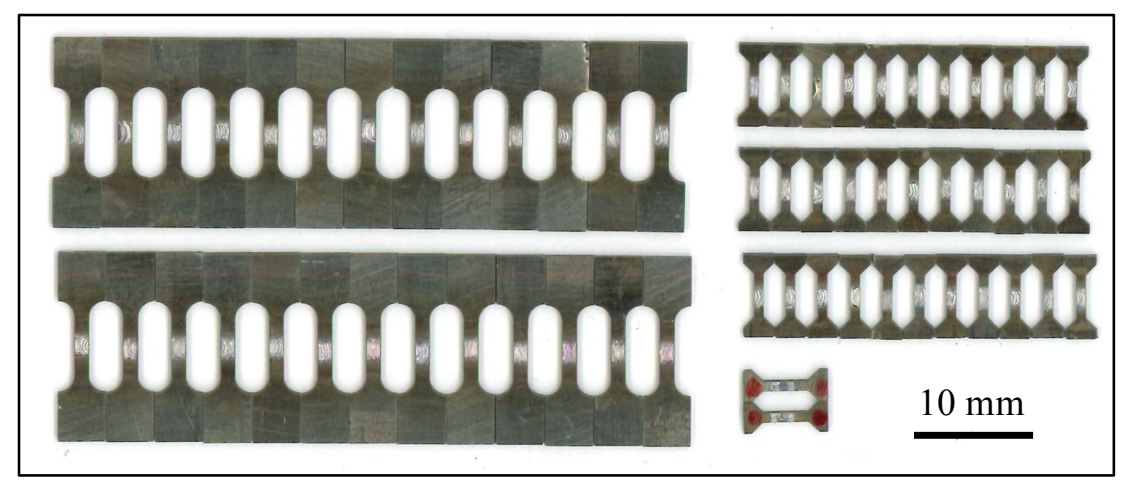

Figure 4: Image of welded C37M specimens prior to surface machining. Red dots denote specimens with fusion zones far from the center of the gauge region of the specimen. 
Samples with fusion zones significantly deviating from the gauge center were placed in a separate batch and machined separately. Examples of these specimens are those with red dots in Figure 4. The result is each welded configuration having two smaller batches, those with centered fusion zones and those without. Ideally, all specimens for irradiation will come from the centered fusion zone batch. Batch traceability was maintained throughout the remainder of the fabrication process.

\subsubsection{Sample marking and identification scheme}

After fabrication all samples were laser engraved according to a predetermined identification scheme. The specimen-marking scheme can be found in Table 2. SS-J2 specimens had a four character marking while due to the small size of the SS-2E specimens the SS-2E specimens were marked in a three-character scheme. The first character in the SS-2E and the first and second character on the SS-J2 specimens provide unique identification of each alloy composition and welded variant. Care was taken to select prefix characters that do not appear to be similar under microscopic investigation to limit ambiguity during post-irradiation sample sorting. In Table 2, "XX" denotes the serial numbering system, i.e. MF01, MF02, etc. Both SS-J2 and SS-2E specimens are marked on each side on alternating ends of the tensile heads. Figure 5 shows the location and example identification markings on both the SS-J2 and SS-2E specimen types. After engraving, samples were dimensioned to determine if the specimens meets the dimensional requirements called out in Appendix B. Those samples meeting dimensional requirements were then deemed ready for irradiation. Those samples that did not meet the stringent requirements were selected for future out-of-pile irradiation testing including either aging or hydrogen loading testing techniques.

Table 2: Specimen ID marking for specimens for weld and irradiation testing

\begin{tabular}{|c|c|c|c|}
\hline $\begin{array}{c}\text { Spec } \\
\text { ID. }\end{array}$ & $\begin{array}{c}\text { Specimen } \\
\text { Type }\end{array}$ & $\begin{array}{c}\text { Material } \\
\text { Code }\end{array}$ & Condition \\
\hline \hline MFXX & SS-J2 & C35M & non-welded \\
\hline M6XX & SS-J2 & C36M & non-welded \\
\hline MVXX & SS-J2 & C37M & non-welded \\
\hline TKXX & SS-J2 & C35MTC01 & non-welded \\
\hline TCXX & SS-J2 & C35MTC03 & non-welded \\
\hline THXX & SS-J2 & C35MTC10 & non-welded \\
\hline N5XX & SS-J2 & C35MN & non-welded \\
\hline FXX & SS-2E & C35M & non-welded \\
\hline IXX & SS-2E & C36M & non-welded \\
\hline VXX & SS-2E & C37M & non-welded \\
\hline KXX & SS-2E & C35MTC01 & non-welded \\
\hline TXX & SS-2E & C35MTC03 & non-welded \\
\hline HXX & SS-2E & C35MTC10 & non-welded \\
\hline NXX & SS-2E & C35MN & non-welded \\
\hline
\end{tabular}

\begin{tabular}{|c|c|c|c|}
\hline $\begin{array}{c}\text { Spec } \\
\text { ID. }\end{array}$ & $\begin{array}{c}\text { Specimen } \\
\text { Type }\end{array}$ & $\begin{array}{c}\text { Material } \\
\text { Code }\end{array}$ & Condition \\
\hline \hline 5WXX & SS-J2 & C35M & welded \\
\hline VWXX & SS-J2 & C37M & welded \\
\hline KWXX & SS-J2 & C35MTC01 & welded \\
\hline TWXX & SS-J2 & C35MTC03 & welded \\
\hline HWXX & SS-J2 & C35MTC10 & welded \\
\hline NWXX & SS-J2 & C35MN & welded \\
\hline AXX & SS-2E & C35M & welded \\
\hline VXX & SS-2E & C37M & welded \\
\hline LXX & SS-2E & C35MTC01 & welded \\
\hline CXX & SS-2E & C35MTC03 & welded \\
\hline OXX & SS-2E & C35MTC10 & welded \\
\hline BXX & SS-2E & C35MN & welded \\
\hline
\end{tabular}


(a)

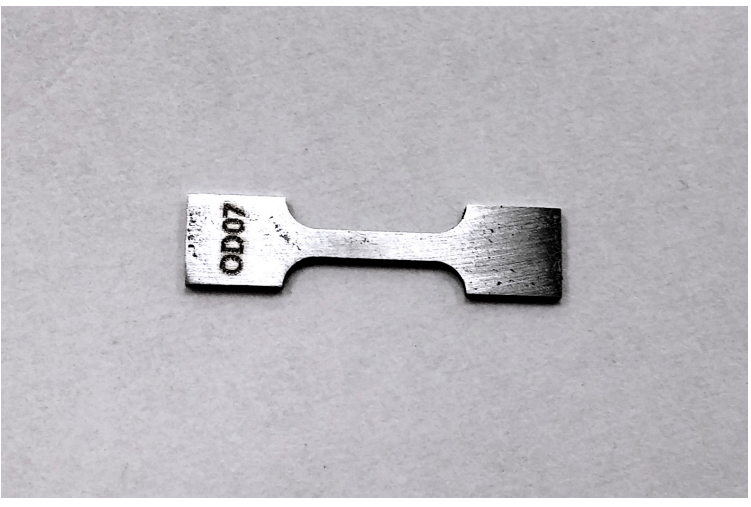

(b)

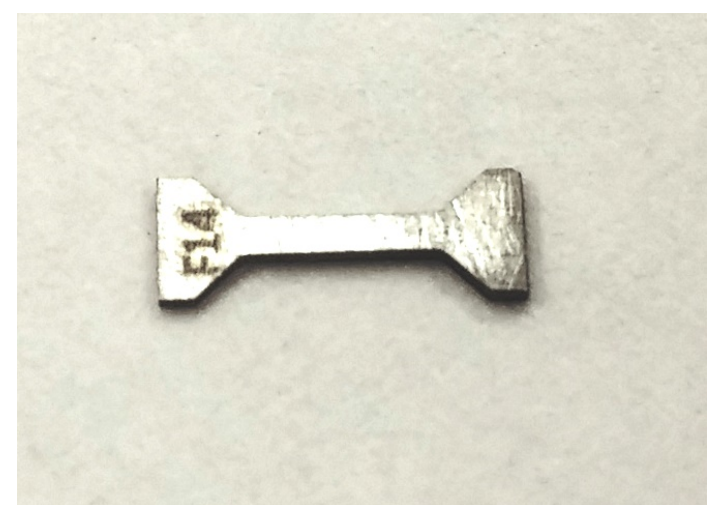

Figure 5: Image of laser engraving positions on sample specimens; (a) position on SS-J2 sample and (b) position on SS-2E sample.

\section{IRRADIATION TEST CONDITIONS}

\subsubsection{Design and configuration of the materials test reactor}

The HFIR was selected as the materials test reactor for this study as it operates with the highest flux reactor-based source of neutrons available in the United States. Due to it's high flux, higher doses can be achieved rapidly with an average of $\sim 6-12$ dpa per year for ferrous based alloys. The high flux is due to the reactor's design where it is a beryllium-reflected, pressurized, light-water-cooled and moderated fluxtrap-type reactor. The core consists of aluminum-clad involute-fuel plates, which currently utilizes highly enriched ${ }^{235} \mathrm{U}$ fuel at a power level of $85 \mathrm{MWt}$. The core is designed with two concentric annular regions. The inner flux trap provides numerous positions for materials irradiation studies using specialized irradiation capsules otherwise known as "rabbits." Figure 6 shows a schematic of the flux trap positions within the HFIR. In Figure 6, three different types of positions are highlighted: target, peripheral target, and hydraulic tube. Each of these positions have uniquely different neutron flux characteristics leading to small variations in capsule accumulated damage dose. Figure 7 shows the nominal axial neutron flux profile for each of the irradiation positions. Each irradiation position can accommodate several rabbits within a single vertical channel and hence the fast neutron flux received by a rabbit (and therefore the samples) will vary based on selected target type and the vertical alignment within the core. The fast neutron flux will also result in slightly varied irradiation temperatures within the rabbit if all other variables are held constant. 


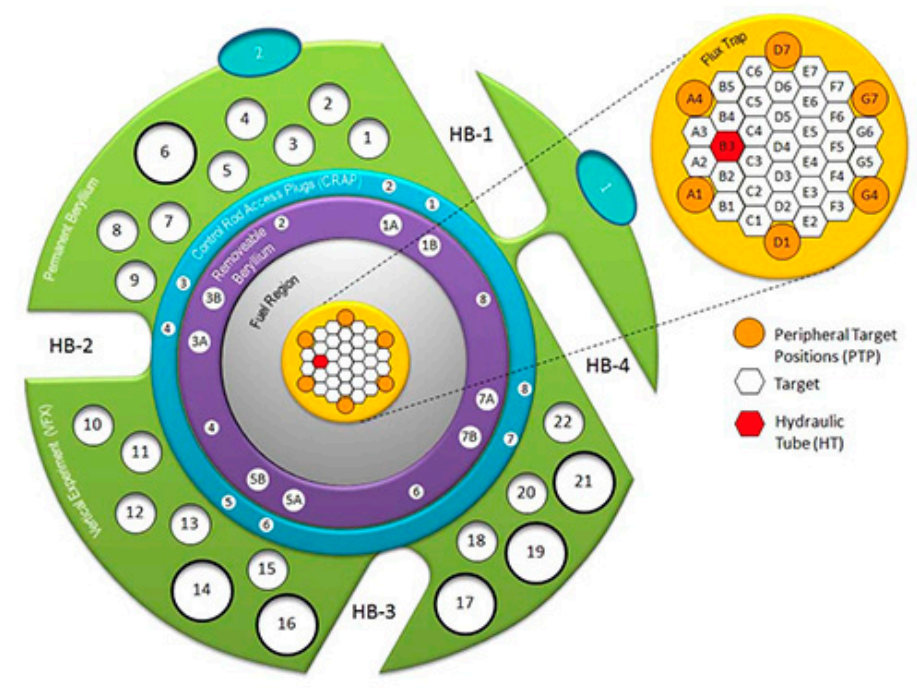

Figure 6: Flux trap irradiation locations in the HFIR.

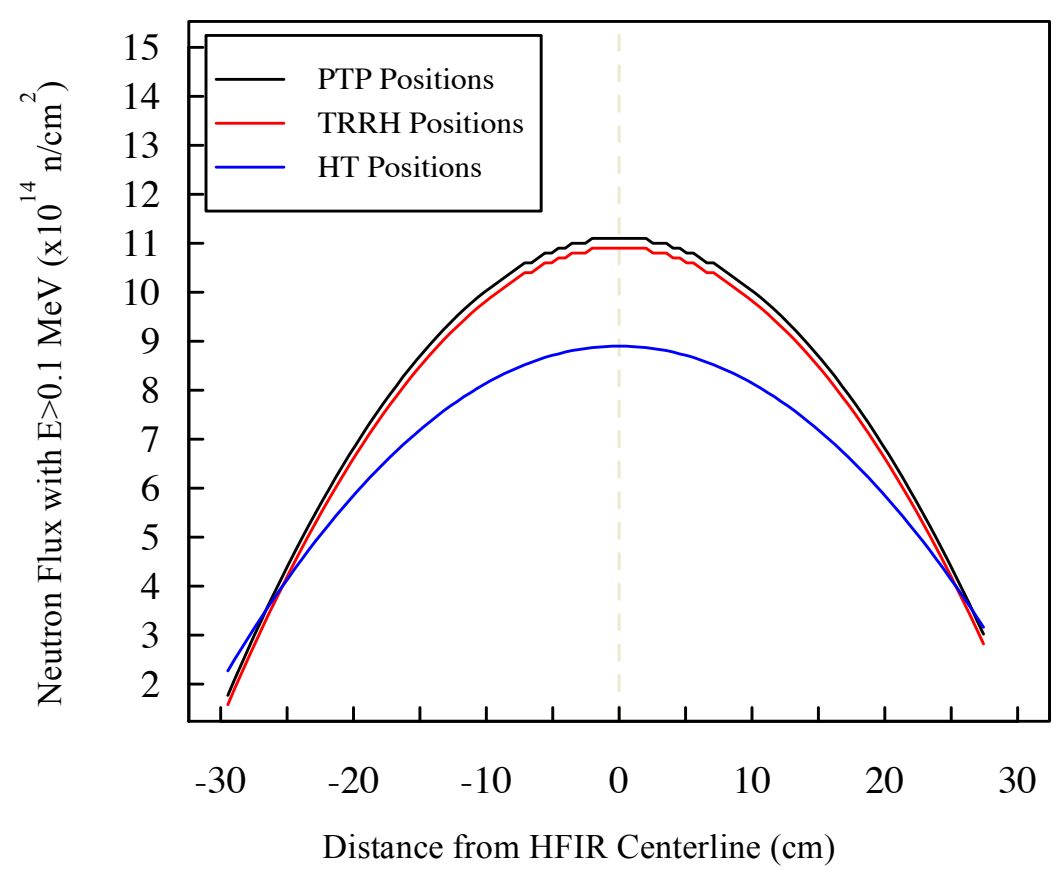

Figure 7: Estimated fast neutron flux at positions within the HFIR. PTP: peripheral target position; TRRH: target rod rabbit holder position; HT: hydraulic tube position.

\subsubsection{Anticipated irradiation conditions}

Radiation-induced effects, such as dislocation loop formation, as well as radiation-enhanced processes, such as precipitation, are known to be strongly temperature dependent. To probe the temperature dependency of the radiation effects within the candidate $\mathrm{Fe}-\mathrm{Cr}-\mathrm{Al}$ alloys three irradiation temperatures were selected: $200^{\circ} \mathrm{C}, 330^{\circ} \mathrm{C}$, and $550^{\circ} \mathrm{C}$. Based on previous irradiation studies on $\mathrm{Fe}-\mathrm{Cr}$ based alloys, 
these three temperatures will probe three different regimes for the $\mathrm{Fe}-\mathrm{Cr}-\mathrm{Al}$ alloys: a dislocation loop dominated regime at $200^{\circ} \mathrm{C}$, a mixed dislocation loop and precipitation dominated regime at $330^{\circ} \mathrm{C}$, and softening or limited dislocation loop dominated regime at and above $550^{\circ} \mathrm{C}$ [11]. The selected temperatures also span a wide range of temperatures seen within current fission reactor designs and possible future designs, hence providing critical data needed for the assessment of candidate welded $\mathrm{Fe}-$ $\mathrm{Cr}-\mathrm{Al}$ alloys for a variety of nuclear power production applications. Along with temperature, the irradiation campaign will also investigate the radiation tolerance of the $\mathrm{Fe}-\mathrm{Cr}-\mathrm{Al}$ alloys as a function of dose. Here, the target doses were selected as $2 \mathrm{dpa}, 8 \mathrm{dpa}$, and $16 \mathrm{dpa}$. This dose range spans a typical lifetime accumulated dose for a fuel cladding component. Also, doses above $16 \mathrm{dpa}$ will extend past the expected lifetime of the program and have much larger sample activities limiting possibilities for extensive post-irradiation examination efforts. Based on the experimental test matrix, nine unique rabbit configurations are needed. The anticipated insertion date for all rabbits is cycle 462 of the HFIR that is expected to commence on October $6^{\text {th }}, 2015$. Based on the flux trap configuration for this cycle, 9 positions have been selected for the irradiation campaign all of which are the peripheral target position (PTP) positions. The resulting test matrix based on the positions, insertion date, and irradiation conditions are provided in Table 3.

Table 3: Position of capsules for irradiation within the HFIR. Nominal dose (dpa) is calculated based on a pure-Fe specimen. Dates are approximant.

\begin{tabular}{|l|c|c|c|c|c|c|c|c|}
\hline $\begin{array}{c}\text { HFIR } \\
\text { Position }\end{array}$ & $\begin{array}{c}\text { Capsule } \\
\text { ID }\end{array}$ & $\begin{array}{c}\text { Target } \\
\text { Temp } \\
\left({ }^{\circ} \mathbf{C}\right)\end{array}$ & $\begin{array}{c}\text { Number } \\
\text { of Cycles }\end{array}$ & $\begin{array}{c}\text { Nominal } \\
\text { Capsule } \\
\text { Avg. Flux } \\
\left(\mathbf{n} / \mathbf{c m}^{2} \mathbf{s}\right)\end{array}$ & $\begin{array}{c}\text { Nominal } \\
\text { Capsule } \\
\text { Avg. } \\
\text { Fluence } \\
\left(\mathbf{n} / \mathbf{c m}^{2}\right)\end{array}$ & $\begin{array}{c}\text { Nominal } \\
\text { Capsule } \\
\text { Average } \\
\text { Dose (dpa) }\end{array}$ & $\begin{array}{c}\text { Capsule } \\
\text { Insertion } \\
\text { Date }\end{array}$ & $\begin{array}{c}\text { Capsule } \\
\text { Release } \\
\text { Date }\end{array}$ \\
\hline \hline PTP D7 5 & FCAT01 & 200 & 1 & $1.10 \times 10^{15}$ & $2.81 \times 10^{21}$ & 1.9 & $10 / 6 / 15$ & $10 / 30 / 15$ \\
\hline PTP G4 5 & FCAT02 & 200 & 4 & $1.10 \times 10^{15}$ & $9.12 \times 10^{21}$ & 7.6 & $10 / 6 / 15$ & $3 / 18 / 16$ \\
\hline PTP G7 5 & FCAT03 & 200 & 8 & $1.10 \times 10^{15}$ & $1.79 \times 10^{22}$ & 15.2 & $10 / 6 / 15$ & $1 / 10 / 17$ \\
\hline PTP D7 6 & FCAT04 & 330 & 1 & $1.08 \times 10^{15}$ & $2.24 \times 10^{21}$ & 1.9 & $10 / 6 / 15$ & $10 / 30 / 15$ \\
\hline PTP G4 6 & FCAT05 & 330 & 4 & $1.08 \times 10^{15}$ & $8.96 \times 10^{21}$ & 7.4 & $10 / 6 / 15$ & $3 / 18 / 16$ \\
\hline PTP G7 6 & FCAT06 & 330 & 8 & $1.08 \times 10^{15}$ & $1.79 \times 10^{22}$ & 14.9 & $10 / 6 / 15$ & $1 / 10 / 17$ \\
\hline PTP D7 5 & FCAT07 & 550 & 1 & $1.10 \times 10^{15}$ & $2.81 \times 10^{21}$ & 1.9 & $10 / 6 / 15$ & $10 / 30 / 15$ \\
\hline PTP G4 5 & FCAT08 & 550 & 4 & $1.10 \times 10^{15}$ & $9.12 \times 10^{21}$ & 7.6 & $10 / 6 / 15$ & $3 / 18 / 16$ \\
\hline PTP G7 5 & FCAT09 & 550 & 8 & $1.10 \times 10^{15}$ & $1.79 \times 10^{22}$ & 15.2 & $10 / 6 / 15$ & $1 / 10 / 17$ \\
\hline
\end{tabular}

\section{DESCRIPTION OF HFIR RABBIT DESIGN}

\subsubsection{General design concepts}

The anticipated flux trap positions provided in Table 3 limit the overall size of the rabbit configuration that can be used for the irradiation campaign. The design used here was based off of a rabbit configuration previously used for HFIR irradiations of 36 SS-J2 tensile specimens. For this program, the design was modified to accommodate both SS-J2 and SS-2E tensile bars. The resulting design is an extremely versatile design where the rabbit can be loaded solely with SS-J2 specimens, SS-2E specimens, or a mixture of the two specimen types. Here, the rabbit configuration was selected to contain 27 SS-J2 tensile bars and 18 SS-2E tensile bars. The rabbit configuration can also handle loading of 12 passive $\mathrm{SiC}$ thermometry specimens to validate that the modeled target irradiation temperatures are 
achieved during the irradiation. The rabbit is configured to house three separate sub-assemblies or modules within the primary outer containment. This modular design has proven to provide ease of disassembly during hot cell operations after irradiation. The result is a design that is both versatile and robust. A three-dimensional rendering of the design is provided in Figure 8 while detailed drawings are provided in Appendix B.

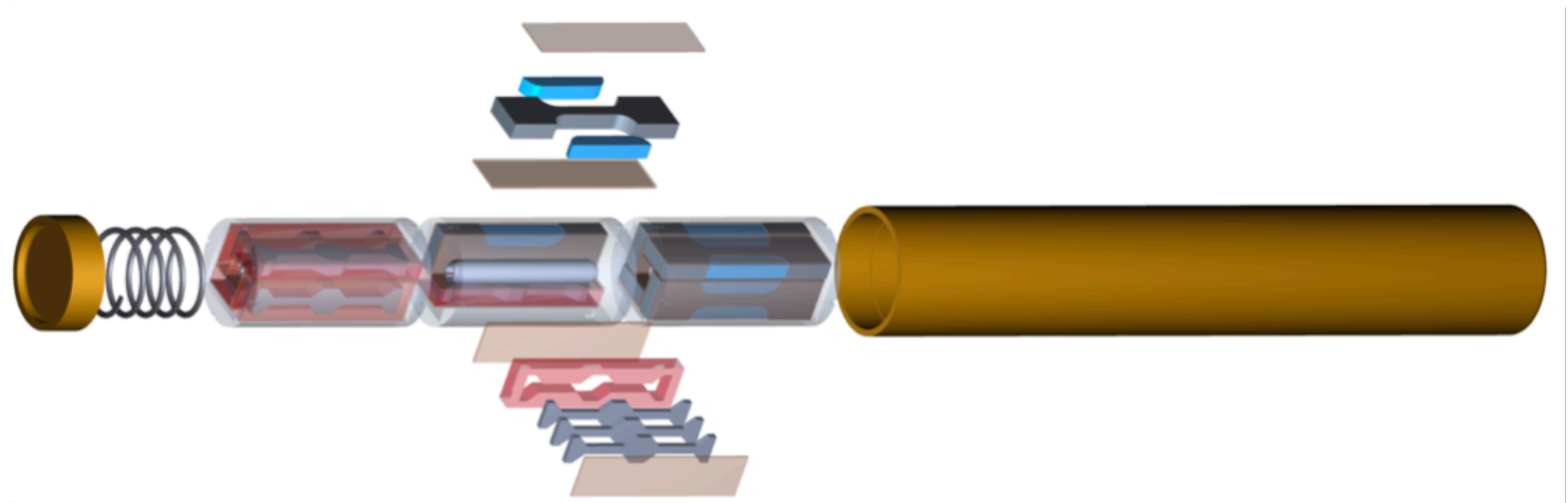

Figure 8: Finalized HFIR rabbit design for irradiation of welded and non-welded tensile specimens.

\subsubsection{Determination of SS-2E thermal equivalency}

The capsule layout detailed in Figure 8 contains multiple specimen configurations including sets of SS-J2, $0.6 \mathrm{~mm}$ thick SS-2E, and $0.4 \mathrm{~mm}$ thick SS-2E specimens. This general configuration of specimens was created to analyze and verify thermal equivalency between the different configurations. The motivation was to develop a modular specimen holder geometry that would provide the ability to irradiate various specimen geometries without having to create unique designs for each loading configuration. The concept was based on thermal mass and contact interfaces. Each specimen batch was fitted with complimentary parts (chevrons, liners, sub-holders, etc.) to make the total subassembly resemble identical 'slugs' of material with the same thermal mass and contact resistances. This would allow the unique specimen batches to perform identically, provided a given specimen holder outer diameter to control the capsule gas gap.

ANSYS Finite Element Analysis software was used to perform the thermal analysis for this novel design concept. In order to prove thermal equivalency, the thermal performance of the holder assembly containing only SS-J2 specimens (i.e. the far right sub-assembly in Figure 8) was directly compared to the general loaded holder assembly (middle sub-assembly in Figure 8). The thermal loads for the three configurations, SS-J2, $0.6 \mathrm{~mm}$ thick SS-2E, and $0.4 \mathrm{~mm}$ thick SS-2E, were $28.8 \mathrm{~W}, 28 \mathrm{~W}$, and $28 \mathrm{~W}$ respectively (i.e. roughly a $2 \%$ discrepancy between each specimen set). This difference of heat loads is small relatively to machining tolerances and thermal modeling uncertainties. Moreover, the specimen temperatures ranges for the different configurations are small. Figure 9 shows the specimen performance for different loading configurations. The $550^{\circ} \mathrm{C}$ design case was used for this demonstration, as the highest temperature case generally produces the most variations in temperature (i.e. worst case). Note that the samples are loaded as a stack, with location 1 being oriented towards the capsule center and location 3 being oriented towards the holder outer wall. Also, the $0.6 \mathrm{~mm}$ thick SS-2E stack only contains 2 specimens. 


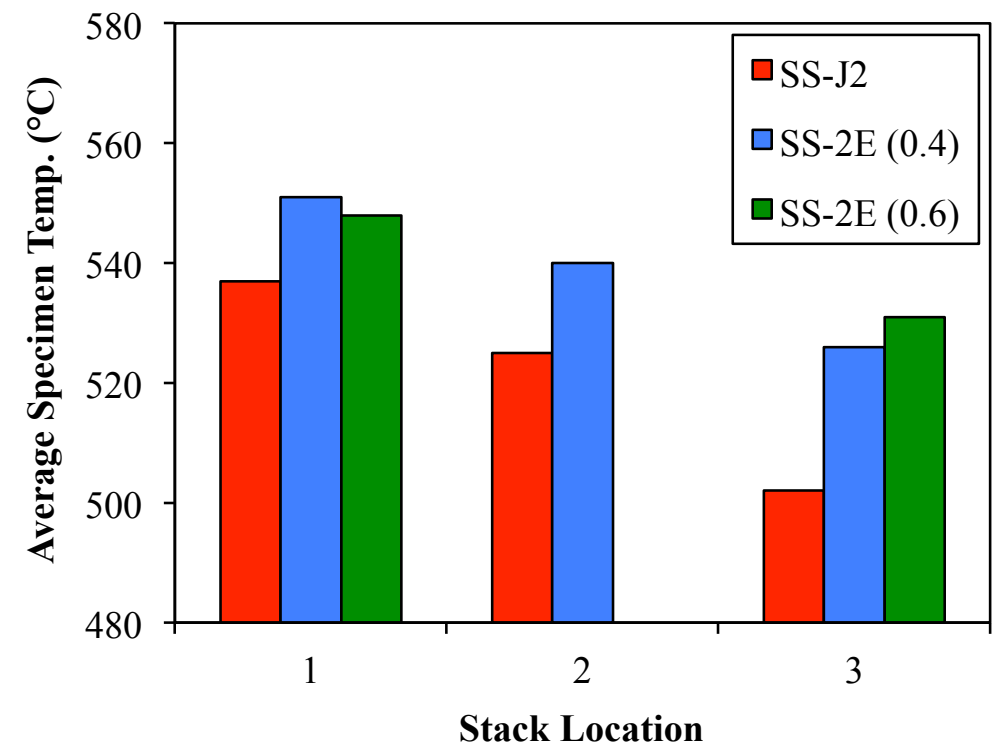

Figure 9. Average Specimen Temperature comparison for the different loading configurations $\left(550^{\circ} \mathrm{C}\right.$ case).

The SS-2E specimens also have a smaller temperature gradient than its larger SS-J2 counterparts. This provides a more continuous temperature in the gauge length of the specimen which allows for more controlled PIE testing. Figure 10 shows a specimen temperature contour plot comparison between the SS$\mathrm{J} 2$ loaded configuration, and the general loaded configuration that includes SS-J2, $0.6 \mathrm{~mm}$ thick SS-2E, and $0.4 \mathrm{~mm}$ thick SS-2E specimens. As seen in Figure 10, both SS-2E specimen thicknesses exhibit a reduced temperature gradient when compared to the SS-J2 sets. By tracking the sample loading during assembly and coupling it to the 3D thermal analysis shown in Figure 10, any potential temperature gradients effects can be accounted for during PIE. This will allow for a more accurate analysis of radiation effects in candidate $\mathrm{Fe}-\mathrm{Cr}-\mathrm{Al}$ alloys.
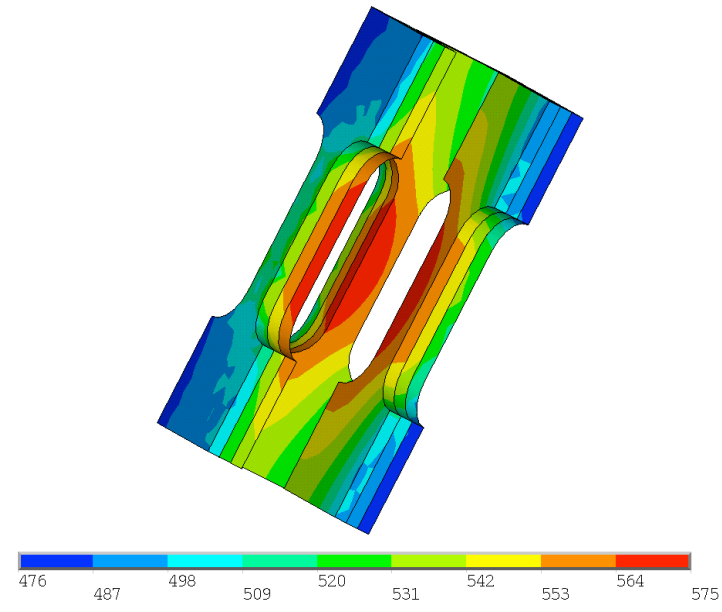

SS-J2
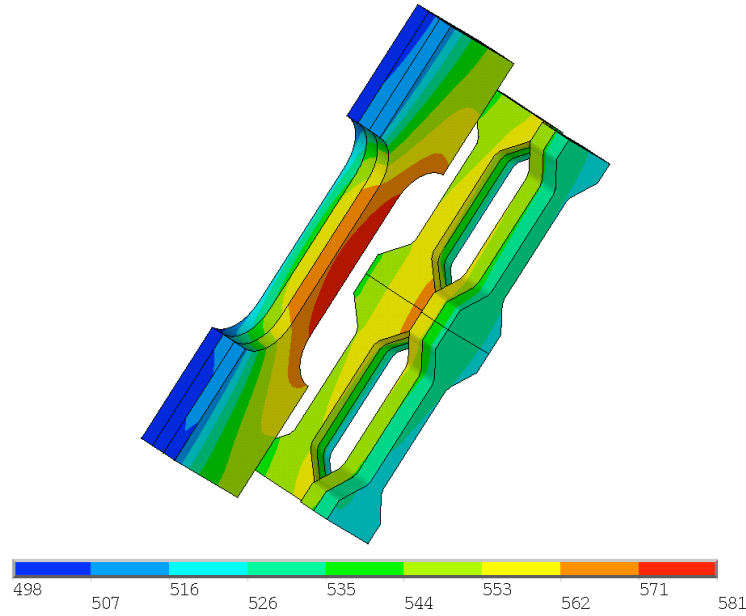

General

Figure 10. Temperature contour plot comparison between the SS-J2 (only) configuration and the general configuration. 


\subsubsection{Thermal analysis of irradiation experiment}

After determination of thermal equivalency, the specimen temperatures for the loading configuration to be used for the irradiation can be modeled. To control the specimen temperatures during irradiation several variables can be tuned including the axial location within the HFIR, the fill gas, and the radial gap between the specimen holder (transparent geometries in Figure 8) and the outer housing. As seen in Figure 8, the specimens are grouped in stacks of three and are loaded into the four quadrants of the square cutout holder. The selected configuration only uses SS-2E specimens with $0.4 \mathrm{~mm}$ thickness. This configuration maximizes specimen loading but does not provide a constant temperature for each specimen in the group. Hence, individual specimen temperatures must be considered resulting in the thermal analysis determining the individual specimens temperatures and denotes them as 'outer', 'middle', and 'inner' specimens. To meet the design temperature specified in Table 3, He was selected as the fill gas. The holder diameters were optimized for the various HFIR positions with ANSYS based on the analysis in Section 5.1.2. The resulting temperatures, associated HFIR positions, and holder diameters can be seen in Table 4.

Table 4: Thermal analysis conditions for a mixed SS-2E and SS-J2 tensile specimens' capsule.

\begin{tabular}{|c|c|c|c|c|c|c|}
\hline \multirow{2}{*}{$\begin{array}{c}\text { Target } \\
\text { Temperature }\end{array}$} & \multirow{2}{*}{$\begin{array}{c}\text { HFIR } \\
\text { Position }\end{array}$} & \multirow{2}{*}{$\begin{array}{c}\text { Holder } \\
\text { Diameter }\end{array}$} & \multirow{2}{*}{$\begin{array}{c}\text { Specimen } \\
\text { Location }\end{array}$} & \multicolumn{3}{|c|}{ Specimen Analysis Conditions } \\
\hline & & & & Avg. & Min. & Max. \\
\hline \multirow{3}{*}{$200^{\circ} \mathrm{C}$} & \multirow{3}{*}{ PTP 5} & \multirow{3}{*}{$9.43 \mathrm{~mm}$} & Outer & $199^{\circ} \mathrm{C}$ & $171^{\circ} \mathrm{C}$ & $242^{\circ} \mathrm{C}$ \\
\hline & & & Middle & $222^{\circ} \mathrm{C}$ & $177^{\circ} \mathrm{C}$ & $263^{\circ} \mathrm{C}$ \\
\hline & & & Inner & $235^{\circ} \mathrm{C}$ & $181^{\circ} \mathrm{C}$ & $277^{\circ} \mathrm{C}$ \\
\hline \multirow{3}{*}{$330^{\circ} \mathrm{C}$} & \multirow{3}{*}{ PTP 6} & \multirow{3}{*}{$9.28 \mathrm{~mm}$} & Outer & $314^{\circ} \mathrm{C}$ & $288^{\circ} \mathrm{C}$ & $351^{\circ} \mathrm{C}$ \\
\hline & & & Middle & $336^{\circ} \mathrm{C}$ & $292^{\circ} \mathrm{C}$ & $373^{\circ} \mathrm{C}$ \\
\hline & & & Inner & $348^{\circ} \mathrm{C}$ & $300^{\circ} \mathrm{C}$ & $386^{\circ} \mathrm{C}$ \\
\hline \multirow{3}{*}{$550^{\circ} \mathrm{C}$} & \multirow{3}{*}{ PTP 5} & \multirow{3}{*}{$9.00 \mathrm{~mm}$} & Outer & $502^{\circ} \mathrm{C}$ & $476^{\circ} \mathrm{C}$ & $543^{\circ} \mathrm{C}$ \\
\hline & & & Middle & $525^{\circ} \mathrm{C}$ & $484^{\circ} \mathrm{C}$ & $563^{\circ} \mathrm{C}$ \\
\hline & & & Inner & $537^{\circ} \mathrm{C}$ & $488^{\circ} \mathrm{C}$ & $575^{\circ} \mathrm{C}$ \\
\hline
\end{tabular}

\section{SPECIMEN LOADING LISTS AND RABBIT CONFIGURATIONS}

As discussed previously, the current configuration allows for 27 SS-J2 tensile bars and 18 SS-2E tensile bars within a single rabbit. Generally, several specimens of each type (SS-J2 or SS-2E) are needed for each specimen type and configuration (alloy and either welded or non-welded, respectively) resulting in a limited number of alloys that can be evaluated in a single rabbit. Due to this limitation, several alloys will not be included in the irradiation including C35M01TC and C35M10TC in either configuration while a $\mathrm{C} 36 \mathrm{M}$ alloy in the welded configuration and in the non-welded SS-2E configuration will not be fielded as well. These alloys/configurations were eliminated from the irradiation plan as they were deemed the least significant in meeting the objectives of the irradiation campaign. Several other alloys under investigation from other programs are included in the tests to enable cross comparison of different alloy concepts. The resulting breakdown of alloys and specimens on a per rabbit basis are provided in Table 5. A fully detailed loading list based on compiling Table 3 and Table 5 is presented in Appendix C. 
Table 5: Single rabbit loading list by alloy type, specimen type, and configuration. Alloys FCA-ODS and $\mathrm{C06M}$ are $\mathrm{Fe}-\mathrm{Cr}-\mathrm{Al}$ alloys currently of interest in other irradiation programs.

\begin{tabular}{|l|l|c|c|}
\hline \multicolumn{1}{|c|}{$\begin{array}{c}\text { Material } \\
\text { Code }\end{array}$} & Condition & $\begin{array}{c}\text { Number of } \\
\text { SS-J2 per } \\
\text { rabbit }\end{array}$ & $\begin{array}{c}\text { Number of } \\
\text { SS-2E per } \\
\text { rabbit }\end{array}$ \\
\hline \hline C35M & non-welded & 3 & 2 \\
\hline C36M & non-welded & 3 & - \\
\hline C37M & non-welded & 3 & 2 \\
\hline C06M & non-welded & 3 & - \\
\hline FCA-ODS & non-welded & 2 & - \\
\hline C35MN & non-welded & 2 & 2 \\
\hline C35M03TC & non-welded & 3 & 2 \\
\hline C35M & welded & 2 & 3 \\
\hline C37M & welded & 2 & 2 \\
\hline C35MN & welded & 2 & 3 \\
\hline C35M03TC & welded & 2 & \\
\hline
\end{tabular}

\section{SCHEDULE}

At the time of this report all design work has been completed and samples have been fabricated for irradiation. Currently, samples are undergoing final inspection before assembly of the rabbits for irradiation. At the time of assembly, final build sheets including dimensional inspection will be issued for all rabbits deeming the samples capable of insertion into HFIR. All irradiation rabbits are anticipated to be inserted in HFIR cycle 462 with a start date on October $6^{\text {th }}, 2015$. The first batch of rabbits and the samples contained within will be removed from HFIR on October $30^{\text {th }}, 2015$. Typically, rabbits are held for 30-60 days before shipment to the Irradiated Materials Examination and Testing (IMET) hot cell facility where rabbits are deconsolidated and individual samples are ready for PIE. The result is the first group of rabbits are expected to be ready for PIE for the first quarter of the 2016 fiscal year. A breakdown of expected dates are provided in Table 6.

Table 6: Anticipated irradiation campaign schedule. Dates are approximant.

\begin{tabular}{|c|c|c|c|c|c|c|}
\hline Capsule ID & $\begin{array}{c}\text { Target } \\
\text { Temp }\left({ }^{\circ} \mathbf{C}\right)\end{array}$ & $\begin{array}{c}\text { Number of } \\
\text { Cycles }\end{array}$ & $\begin{array}{c}\text { Average } \\
\text { Capsule } \\
\text { Dose (dpa) }\end{array}$ & $\begin{array}{c}\text { Capsule } \\
\text { Insertion } \\
\text { Date }\end{array}$ & $\begin{array}{c}\text { Capsule } \\
\text { Release } \\
\text { Date }\end{array}$ & $\begin{array}{c}\text { Shipment } \\
\text { Date to } \\
\text { IMET }\end{array}$ \\
\hline FCAT01 & 200 & 1 & 1.9 & $10 / 6 / 15$ & $10 / 30 / 15$ & $1 / 4 / 16$ \\
\hline FCAT02 & 200 & 4 & 7.6 & $10 / 6 / 15$ & $3 / 18 / 16$ & $5 / 18 / 16$ \\
\hline FCAT03 & 200 & 8 & 15.2 & $10 / 6 / 15$ & $1 / 10 / 17$ & $3 / 10 / 17$ \\
\hline FCAT04 & 330 & 1 & 1.9 & $10 / 6 / 15$ & $10 / 30 / 15$ & $1 / 4 / 16$ \\
\hline FCAT05 & 330 & 4 & 7.4 & $10 / 6 / 15$ & $3 / 18 / 16$ & $5 / 18 / 16$ \\
\hline FCAT06 & 330 & 8 & 14.9 & $10 / 6 / 15$ & $1 / 10 / 17$ & $3 / 10 / 17$ \\
\hline FCAT07 & 550 & 1 & 1.9 & $10 / 6 / 15$ & $10 / 30 / 15$ & $1 / 4 / 16$ \\
\hline FCAT08 & 550 & 4 & 7.6 & $10 / 6 / 15$ & $3 / 18 / 16$ & $5 / 18 / 16$ \\
\hline FCAT09 & 550 & 8 & 15.2 & $10 / 6 / 15$ & $1 / 10 / 17$ & $3 / 10 / 17$ \\
\hline
\end{tabular}




\section{REFERENCES}

[1] B.A. Pint, S. Dryepondt, K.A. Unocic, D.T. Hoelzer, Development of ODS FeCrAl for compatibility in fusion and fission energy applications, Jom, 66 (2014) 2458-2466.

[2] B.A. Pint, K.A. Terrani, M.P. Brady, T. Cheng, J.R. Keiser, High temperature oxidation of fuel cladding candidate materials in steam-hydrogen environments, Journal of Nuclear Materials, 440 (2013) $420-427$.

[3] J. Tusek, A. Kosmac, U. Nartnik, A. Dejan, Welding of heat-resistant $20 \% \mathrm{Cr}-5 \% \mathrm{Al}$ steels, Z. Metallkd., 93 (2002) 310-314.

[4] J.R. Regina, J.N. Dupont, A.R. Marder, The effect of chromium on the weldability and microstructure of Fe-Cr-Al weld cladding, Welding Journal, 86 (2007) 170-178.

[5] H. El Kadiri, Y. Bienvenu, K. Solanki, M.F. Horstemeyer, P.T. Wang, Creep and tensile behaviors of $\mathrm{Fe}-\mathrm{Cr}-\mathrm{Al}$ foils and laser microwelds at high temperature, Materials Science and Engineering: A, 421 (2006) 168-181.

[6] J.N. Dupont, J.R. Regina, K. Adams, Improving the weldability of fecral weld overlay coatings, in: Fossil Energy Materials Conference, ORNL, Oak Ridge National Laboratory, 2007, pp. 131-137.

[7] S. Zinkle, J. Busby, Structural materials for fission and fusion energy, Materials Today, 12 (2009) 12 19.

[8] K.G. Field, X. Hu, K.C. Littrell, Y. Yamamoto, L.L. Snead, Radiation tolerance of neutron-irradiated model Fe-Cr-Al alloys, Journal of Nuclear Materials, 465 (2015) 746-755.

[9] K.G. Field, M.N. Gussev, Y. Yamamoto, X. Hu, R.H. Howard, Preliminary Studies on the Fabrication and Characterization of Fe-Cr-Al Alloys Designed to Have Enhanced Weldability and Radiation Tolerance, in, Oak Ridge National Laboratory, Oak Ridge, TN, 2015.

[10] S. Kobayashi, T. Takasugi, Mapping of $475^{\circ} \mathrm{C}$ embrittlement in ferritic $\mathrm{Fe}-\mathrm{Cr}-\mathrm{Al}$ alloys, Scripta Materialia, 63 (2010) 1104-1107.

[11] A. Hishinuma, A. Kohyama, R. Klueh, D. Gelles, W. Dietz, K. Ehrlich, Current status and future R\&D for reduced-activation ferritic/martensitic steels, Journal of Nuclear Materials, 258-263 (1998) 193204. 


\section{DIRATS \\ LABORATORIES}

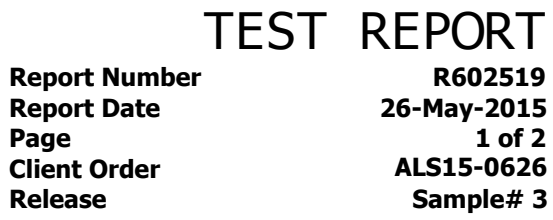

\begin{tabular}{ll}
\hline RECEIVED & 1 Sawn Section approx. 1/4" x 1/2" $\times 1 "$ \\
IDENTIFICATION & Sample\# 3 ID: C36M3 \\
MATERIAL & Fe-Cr-Al \\
TEST PER & Client Instructions \\
RETURN & All Material
\end{tabular}

PROPERTIES AS SUPPLIED

Quantitative Analysis by ICP-OE

$\begin{array}{rr}\mathrm{Al} & 6.00 \% \\ \mathrm{~B} & <0.001 \% \\ \mathrm{Ce} & <0.01 \% \\ \mathrm{Co} & <0.01 \% \\ \mathrm{Cr} & 12.98 \% \\ \mathrm{Cu} & <0.01 \% \\ \mathrm{Fe} & 78.80 \% \\ \mathrm{Hf} & <0.01 \% \\ \mathrm{La} & <0.01 \% \\ \mathrm{Mn} & <0.01 \% \\ \mathrm{Mo} & 1.98 \% \\ \mathrm{Nb} & <0.01 \% \\ \mathrm{Ni} & <0.01 \% \\ \mathrm{P} & <0.002 \% \\ \mathrm{Si} & 0.18 \% \\ \mathrm{Ti} & 0.01 \% \\ \mathrm{~V} & <0.01 \% \\ \mathrm{~W} & <0.01 \% \\ \mathrm{Y} & 0.04 \% \\ \mathrm{Zr} & <0.01 \%\end{array}$




\section{DIRATS}

UT-Battelle, LLC

ORNL Fuel Cycle \& Isotopes Division

Oak Ridge, TN 37831-6083

SAMPLE Sample\# 11 ID: C35M3

PROPERTIES AS SUPPLIED

Quantitative Analysis by ICP-OE
-Dec-2014

12 of 14

$\begin{array}{rrr}\mathrm{Al} & 5.31 \% \\ \mathrm{~B} & <3 \mathrm{ppm} \\ \mathrm{Ce} & <0.01 \% \\ \mathrm{Co} & <0.01 \% \\ \mathrm{Cr} & 13.06 \% \\ \mathrm{Cu} & <0.01 \% \\ \mathrm{Fe} & 79.43 \% \\ \mathrm{Hf} & <0.01 \% \\ \mathrm{La} & <0.01 \% \\ \mathrm{Mn} & <0.01 \% \\ \mathrm{Mo} & 2.00 \% \\ \mathrm{Nb} & <0.01 \% \\ \mathrm{Ni} & <0.01 \% \\ \mathrm{P} & 0.007 \% \\ \mathrm{Si} & 0.13 \% \\ \mathrm{Ti} & <0.01 \% \\ \mathrm{~V} & <0.01 \% \\ \mathrm{~W} & <0.01 \% \\ \mathrm{Y} & 0.053 \% \\ \mathrm{Zr} & <0.01 \%\end{array}$

Quantitative Analysis by Combustion

$$
\begin{array}{ll}
\text { C } & 0.001 \% \\
\text { S } & <3 \mathrm{ppm}
\end{array}
$$

Quantitative Analysis by IGF

$$
\begin{array}{ll}
\mathrm{O} & 0.0012 \% \\
\mathrm{~N} & 0.0003 \%
\end{array}
$$

\section{Disposition of Chemical Analysis}

For Information

The $<$ Symbol signifies not detected at the detectability limit indicated. 


\section{DIRATS}

UT-Battelle, LLC

ORNL Fuel Cycle \& Isotopes Division

Oak Ridge, TN 37831-6083

SAMPLE Sample\# 12 ID: C36M2

PROPERTIES AS SUPPLIED

Quantitative Analysis by ICP-OE
-Dec-2014

13 of 14

$\begin{array}{cc}\mathrm{Al} & 6.29 \% \\ \mathrm{~B} & <3 \mathrm{ppm} \\ \mathrm{Ce} & <0.01 \% \\ \mathrm{Co} & <0.01 \% \\ \mathrm{Cr} & 13.00 \% \\ \mathrm{Cu} & <0.01 \% \\ \mathrm{Fe} & 78.40 \% \\ \mathrm{Hf} & <0.01 \% \\ \mathrm{La} & <0.01 \% \\ \mathrm{Mn} & <0.01 \% \\ \mathrm{Mo} & 1.99 \% \\ \mathrm{Nb} & <0.01 \% \\ \mathrm{Ni} & <0.01 \% \\ \mathrm{P} & 0.004 \% \\ \mathrm{Si} & 0.20 \% \\ \mathrm{Ti} & <0.01 \% \\ \mathrm{~V} & <0.01 \% \\ \mathrm{~W} & <0.01 \% \\ \mathrm{Y} & 0.059 \% \\ \mathrm{Zr} & <0.01 \%\end{array}$

Quantitative Analysis by Combustion

$$
\begin{array}{ll}
\mathrm{C} & 0.001 \% \\
\mathrm{~S} & <3 \mathrm{ppm}
\end{array}
$$

Quantitative Analysis by IGF

$$
\begin{array}{ll}
\mathrm{O} & 0.0010 \% \\
\mathrm{~N} & 0.0004 \%
\end{array}
$$

Disposition of Chemical Analysis

For Information

The $<$ Symbol signifies not detected at the detectability limit indicated. 


\section{DIRATS}

UT-Battelle, LLC

ORNL Fuel Cycle \& Isotopes Division

Oak Ridge, TN 37831-6083

SAMPLE Sample\# 13 ID: C37M

PROPERTIES AS SUPPLIED

Quantitative Analysis by ICP-OE

$\begin{array}{rr}\mathrm{Al} & 7.22 \% \\ \mathrm{~B} & <3 \mathrm{ppm} \\ \mathrm{Ce} & <0.01 \% \\ \mathrm{Co} & <0.01 \% \\ \mathrm{Cr} & 13.01 \% \\ \mathrm{Cu} & <0.01 \% \\ \mathrm{Fe} & 77.49 \% \\ \mathrm{Hf} & <0.01 \% \\ \mathrm{La} & <0.01 \% \\ \mathrm{Mn} & <0.01 \% \\ \mathrm{Mo} & 1.99 \% \\ \mathrm{Nb} & <0.01 \% \\ \mathrm{Ni} & <0.01 \% \\ \mathrm{P} & 0.004 \% \\ \mathrm{Si} & 0.19 \% \\ \mathrm{Ti} & <0.01 \% \\ \mathrm{~V} & <0.01 \% \\ \mathrm{~W} & <0.01 \% \\ \mathrm{Y} & 0.081 \% \\ \mathrm{Zr} & <0.01 \%\end{array}$

Quantitative Analysis by Combustion

$$
\begin{array}{ll}
\mathrm{C} & 0.001 \% \\
\mathrm{~S} & <3 \mathrm{ppm}
\end{array}
$$

Quantitative Analysis by IGF

$$
\begin{array}{ll}
\mathrm{O} & 0.0026 \% \\
\mathrm{~N} & 0.0002 \%
\end{array}
$$

Disposition of Chemical Analysis

For Information

The $<$ Symbol signifies not detected at the detectability limit indicated.

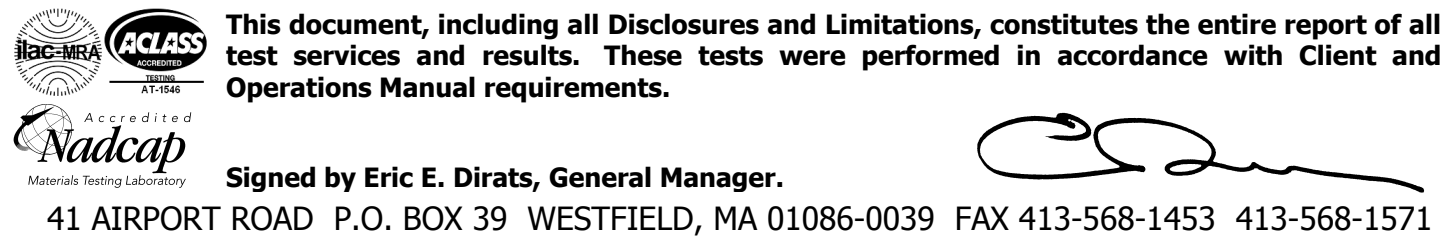




\section{TEST REPORT}

Report Number

Report Date

Page

Client Order

Release
R602521

26-May-2015

1 of 2

ALS15-0626

Sample \#5

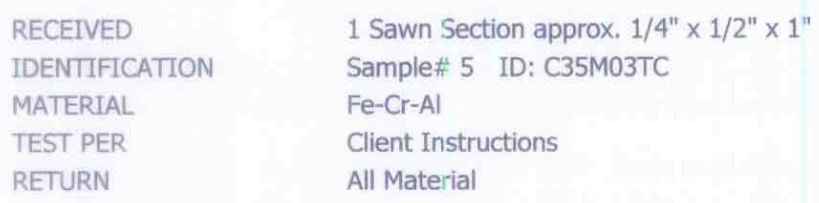

RETURN

PROPERTIES AS SUPPLIED

Quantitative Analysis by ICP-OE

$\begin{array}{rrr}\text { Al } & 5.17 \% \\ \mathrm{~B} & 0.001 \% \\ \mathrm{Ce} & <0.01 \% \\ \mathrm{Co} & <0.01 \% \\ \mathrm{Cr} & 13.03 \% \\ \mathrm{Cu} & <0.01 \% \\ \mathrm{Fe} & 79.34 \% \\ \mathrm{Hi} & <0.01 \% \\ \mathrm{La} & <0.01 \% \\ \mathrm{Mn} & <0.01 \% \\ \mathrm{Mo} & 1.97 \% \\ \mathrm{Nb} & <0.01 \% \\ \mathrm{Ni} & <0.01 \% \\ \mathrm{P} & 0.003 \% \\ \mathrm{Si} & 0.15 \% \\ \mathrm{Ti} & 0.22 \% \\ \mathrm{~V} & <0.01 \% \\ \mathrm{~W} & <0.01 \% \\ \mathrm{Y} & 0.04 \% \\ \mathrm{Zr} & 0.01 \%\end{array}$




\section{TEST REPORT}

Report Number Report Date

Page

Client Order

Release
R602520

26-May-2015

1 of 2

ALS15-0626

Sample\# 4

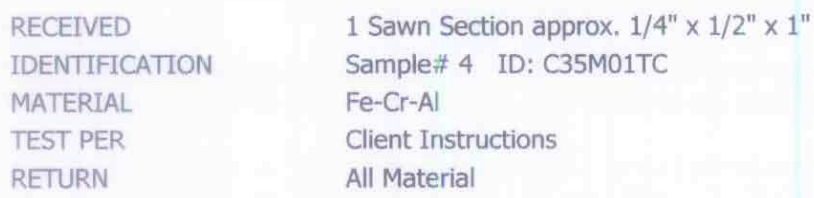

PROPERTIES AS SUPPLIED

Quantitative Analysis by ICP-OE

$\begin{array}{rr}\text { Al } & 5.20 \% \\ \mathrm{~B} & 0.001 \% \\ \mathrm{Ce} & <0.01 \% \\ \mathrm{Co} & <0.01 \% \\ \mathrm{Cr} & 13.00 \% \\ \mathrm{Cu} & <0.01 \% \\ \mathrm{Fe} & 79.51 \% \\ \mathrm{Hf} & <0.01 \% \\ \mathrm{La} & <0.01 \% \\ \mathrm{Mn} & <0.01 \% \\ \mathrm{Mo} & 1.98 \% \\ \mathrm{Nb} & <0.01 \% \\ \mathrm{Ni} & <0.01 \% \\ \mathrm{P} & 0.002 \% \\ \mathrm{Si} & 0.15 \% \\ \mathrm{Ti} & 0.08 \% \\ \mathrm{~V} & <0.01 \% \\ \mathrm{~W} & <0.01 \% \\ \mathrm{Y} & 0.04 \% \\ \mathrm{Zr} & <0.01 \%\end{array}$




\section{TEST REPORT}

Report Number

Report Date

Page

Client Order

Release
R602522

26-May-2015

1 of 2

ALS15-0626

Sample\# 6

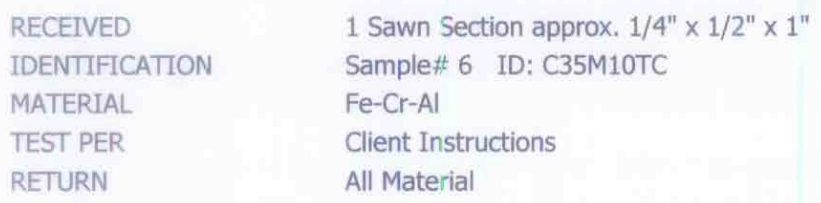

PROPERTIES AS SUPPLIED

Quantitative Analysis by ICP-OE

$\begin{array}{rrr}\text { Al } & 5.14 \% \\ \mathrm{~B} & 0.002 \% \\ \mathrm{Ce} & <0.01 \% \\ \mathrm{Co} & <0.01 \% \\ \mathrm{Cr} & 12.95 \% \\ \mathrm{Cu} & <0.01 \% \\ \mathrm{Fe} & 78.82 \% \\ \mathrm{Hf} & <0.01 \% \\ \mathrm{La} & <0.01 \% \\ \mathrm{Mn} & <0.01 \% \\ \mathrm{Mo} & 1.96 \% \\ \mathrm{Nb} & <0.01 \% \\ \mathrm{Ni} & <0.01 \% \\ \mathrm{P} & <0.002 \% \\ \mathrm{Si} & 0.20 \% \\ \mathrm{Ti} & 0.71 \% \\ \mathrm{~V} & <0.01 \% \\ \mathrm{~W} & 0.01 \% \\ \mathrm{Y} & 0.01 \% \\ \mathrm{Zr} & 0.01 \%\end{array}$




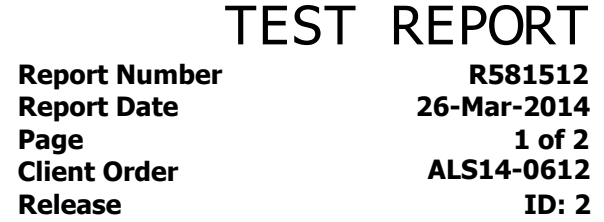

\begin{tabular}{ll}
\hline RECEIVED & 1 Sawn Section approx. 3/8"thk.x 5/8" x 1 1/8" \\
IDENTIFICATION & ID: 2 Name: C35MN6-B \\
MATERIAL & Fe-13Cr \\
TEST PER & Client Instructions \\
RETURN & Specimen
\end{tabular}

\section{PROPERTIES AS SUPPLIED}

Quantitative Analysis by ICP-OE

$\begin{array}{rrl}\text { Al } & 5.11 \% \\ \mathrm{~B} & 10 \mathrm{ppm} \\ \mathrm{Cr} & 13.00 \% \\ \mathrm{Fe} & 78.70 \% \\ \mathrm{Mo} & 1.99 \% \\ \mathrm{Nb} & 0.96 \% \\ \mathrm{P} & <0.002 \% \\ \mathrm{Si} & 0.18 \% \\ \mathrm{Y} & 0.044 \%\end{array}$

Quantitative Analysis by Combustion

$\begin{array}{lr}\text { C } & 0.005 \% \\ \mathrm{~S} & 3 \mathrm{ppm}\end{array}$

41 AIRPORT ROAD P.O. BOX 39 WESTFIELD, MA 01086-0039 FAX 413-568-1453 413-568-1571 


\section{APPENDIX B: CAPSULE ENGINEERING DRAWINGS}

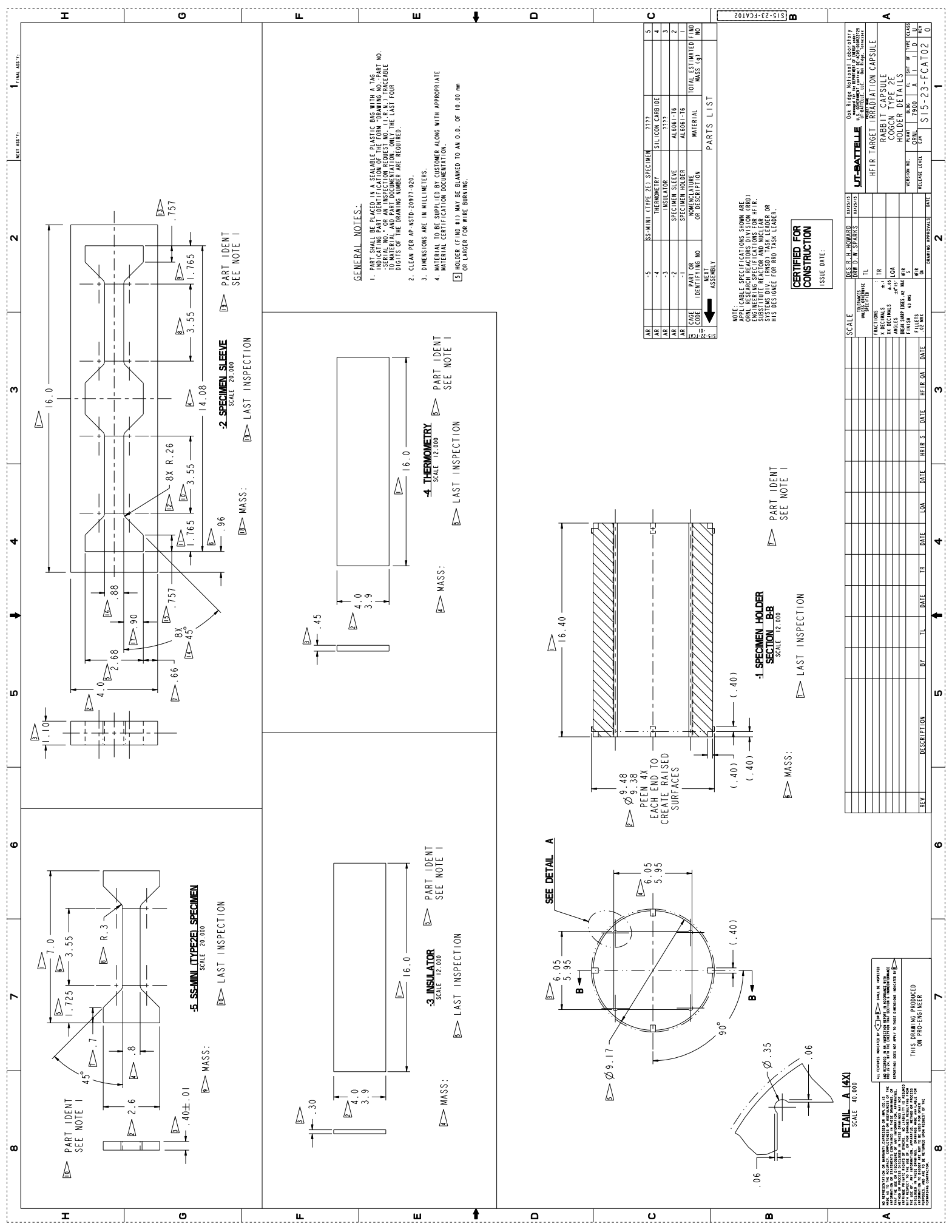




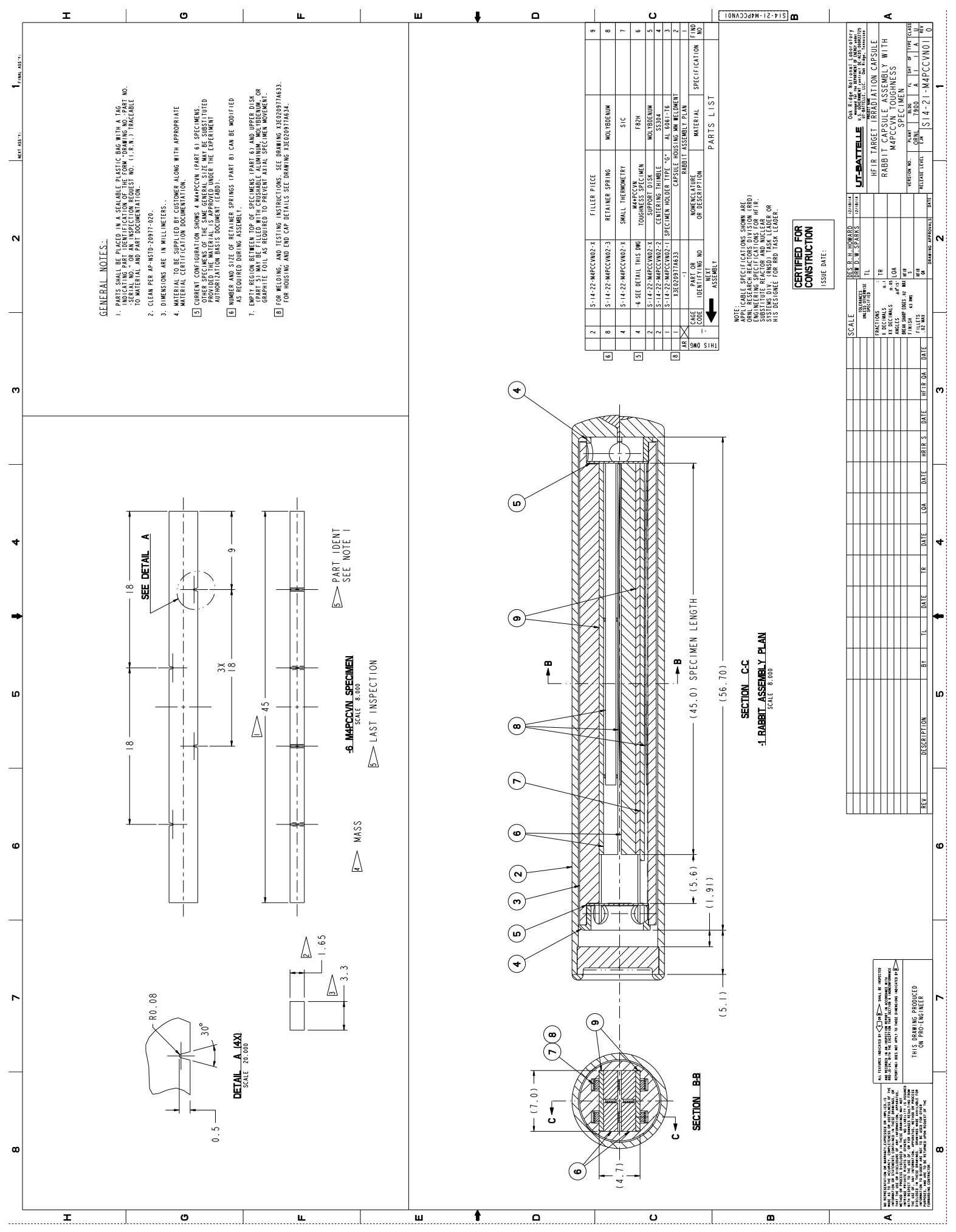




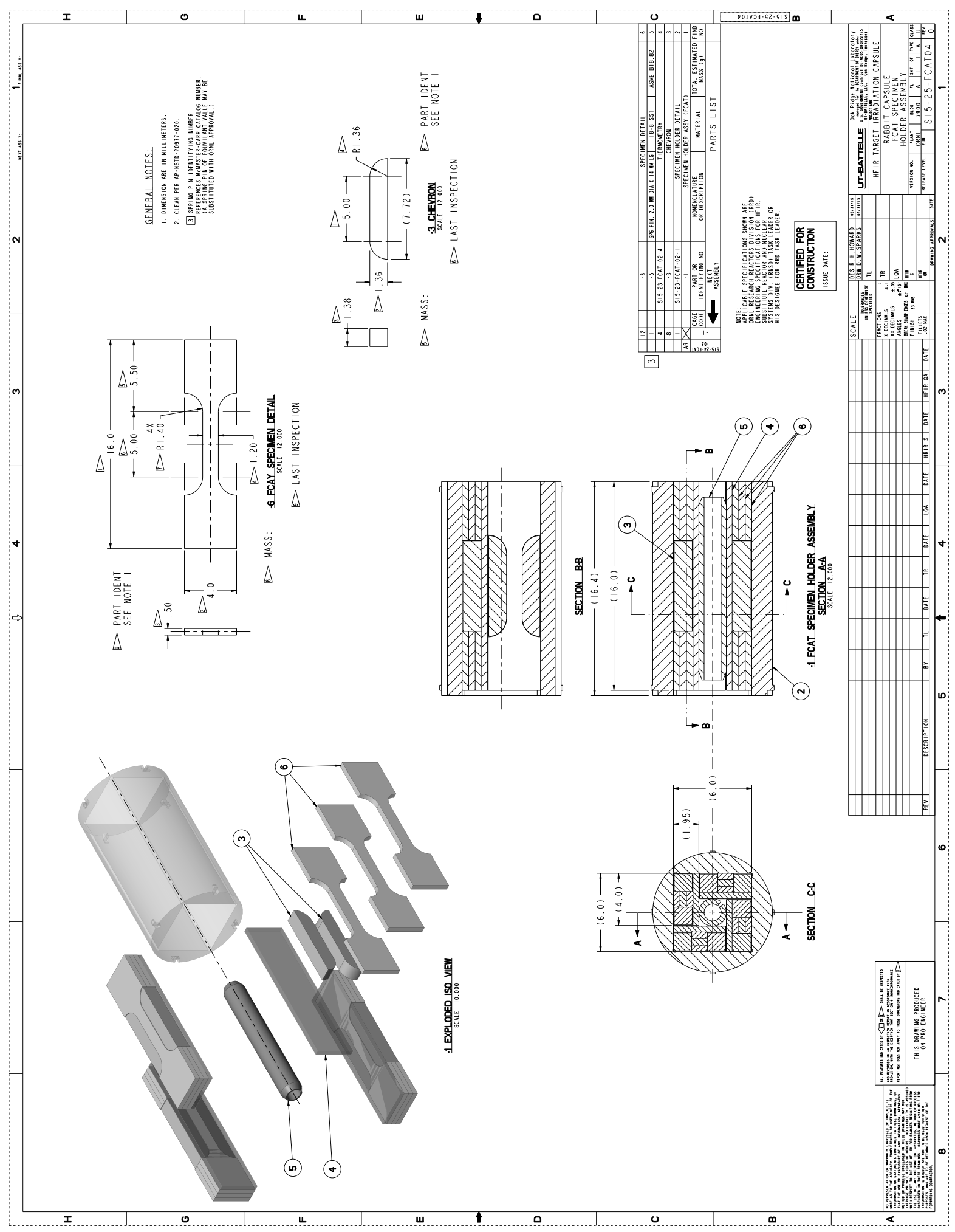




\section{APPENDIX C: CAPSULE LOADING LIST}

\begin{tabular}{|c|c|c|c|c|c|c|c|c|c|c|c|}
\hline \multirow[b]{2}{*}{$\begin{array}{l}\text { Spec.I } \\
\text { D. }\end{array}$} & \multirow[b]{2}{*}{$\begin{array}{l}\text { Specimen } \\
\text { Type** }^{*}\end{array}$} & \multirow[b]{2}{*}{ Material Code* } & \multirow[b]{2}{*}{$\begin{array}{c}\text { Material or Alloy } \\
\text { Composition } \\
\text { (Nominal } \\
\text { Composition, wt.\%)** }\end{array}$} & \multicolumn{8}{|c|}{ Irradiation } \\
\hline & & & & $\begin{array}{c}\text { Target } \\
\text { Temp. }\left({ }^{\circ}\right. \\
\text { C) }\end{array}$ & $\begin{array}{c}\text { HFIR } \\
\text { Position }\end{array}$ & $\begin{array}{c}\text { Avg. } \\
\text { Positio } \\
\text { n Flux } \\
\text { 110 }^{15} \\
\text { n/cm } \\
\text { E }>0.1 \\
\text { MeV } \\
\end{array}$ & $\begin{array}{c}\text { Cycle } \\
\text { s }\end{array}$ & $\begin{array}{l}\text { Exposur } \\
\text { e Time } \\
\text { (s) }\end{array}$ & $\begin{array}{c}\text { Estimate } \\
\text { d } \\
\text { Fluence } \\
\mathbf{x 1 0}^{20} \\
\mathbf{n} / \mathbf{c m}^{2} \\
\mathbf{E}>0.1 \\
\mathrm{MeV} \\
\end{array}$ & $\begin{array}{c}\text { Estimate } \\
\text { d Dose } \\
\text { (dpa) }\end{array}$ & $\begin{array}{c}\text { Rabbits } \\
\text { ID }\end{array}$ \\
\hline BZM01 & M4-PCCVN & $\mathrm{C} 06 \mathrm{M}$ & $\mathrm{Fe}-10 \mathrm{Cr}-6 \mathrm{Al}-2 \mathrm{Mo}$ & 200 & $\begin{array}{c}\text { PTP A1 } \\
4 \\
\end{array}$ & $\begin{array}{c}1.08 \mathrm{E}+1 \\
5 \\
\end{array}$ & 4 & $\begin{array}{c}8.29 \mathrm{E}+0 \\
6 \\
\end{array}$ & $8.96 \mathrm{E}+21$ & 7.4 & FCAB01 \\
\hline BZM02 & M4-PCCVN & $\mathrm{C} 06 \mathrm{M}$ & $\mathrm{Fe}-10 \mathrm{Cr}-6 \mathrm{Al}-2 \mathrm{Mo}$ & 200 & $\begin{array}{c}\text { PTP A1 } \\
4\end{array}$ & $\begin{array}{c}1.08 \mathrm{E}+1 \\
5 \\
\end{array}$ & 4 & $\begin{array}{c}8.29 \mathrm{E}+0 \\
6 \\
\end{array}$ & $8.96 \mathrm{E}+21$ & 7.4 & FCAB01 \\
\hline BM601 & M4-PCCVN & $\mathrm{C} 36 \mathrm{M}$ & $\mathrm{Fe}-13 \mathrm{Cr}-6 \mathrm{Al}-2 \mathrm{Mo}$ & 200 & $\begin{array}{c}\text { PTP A1 } \\
4 \\
\end{array}$ & $\begin{array}{c}1.08 \mathrm{E}+1 \\
5 \\
\end{array}$ & 4 & $\begin{array}{c}8.29 \mathrm{E}+0 \\
6 \\
\end{array}$ & $8.96 \mathrm{E}+21$ & 7.4 & FCAB01 \\
\hline BM602 & M4-PCCVN & $\mathrm{C} 36 \mathrm{M}$ & $\mathrm{Fe}-13 \mathrm{Cr}-6 \mathrm{Al}-2 \mathrm{Mo}$ & 200 & $\begin{array}{c}\text { PTP A1 } \\
4 \\
\end{array}$ & $\begin{array}{c}1.08 \mathrm{E}+1 \\
5 \\
\end{array}$ & 4 & $\begin{array}{c}8.29 \mathrm{E}+0 \\
6 \\
\end{array}$ & $8.96 \mathrm{E}+21$ & 7.4 & FCAB01 \\
\hline BZM03 & M4-PCCVN & $\mathrm{C} 06 \mathrm{M}$ & $\mathrm{Fe}-10 \mathrm{Cr}-6 \mathrm{Al}-2 \mathrm{Mo}$ & 200 & $\begin{array}{c}\text { PTP A4 } \\
4 \\
\end{array}$ & $\begin{array}{c}1.08 \mathrm{E}+1 \\
5 \\
\end{array}$ & 8 & $\begin{array}{c}1.66 \mathrm{E}+0 \\
7 \\
\end{array}$ & $1.79 \mathrm{E}+22$ & 14.9 & FCAB02 \\
\hline BZM04 & M4-PCCVN & $\mathrm{C} 06 \mathrm{M}$ & $\mathrm{Fe}-10 \mathrm{Cr}-6 \mathrm{Al}-2 \mathrm{Mo}$ & 200 & $\begin{array}{c}\text { PTP A4 } \\
4 \\
\end{array}$ & $\begin{array}{c}1.08 \mathrm{E}+1 \\
5 \\
\end{array}$ & 8 & $\begin{array}{c}1.66 \mathrm{E}+0 \\
7 \\
\end{array}$ & $1.79 \mathrm{E}+22$ & 14.9 & FCAB02 \\
\hline BM603 & M4-PCCVN & $\mathrm{C} 36 \mathrm{M}$ & $\mathrm{Fe}-13 \mathrm{Cr}-6 \mathrm{Al}-2 \mathrm{Mo}$ & 200 & $\begin{array}{c}\text { PTP A4 } \\
4 \\
\end{array}$ & $\begin{array}{c}1.08 \mathrm{E}+1 \\
5 \\
\end{array}$ & 8 & $\begin{array}{c}1.66 \mathrm{E}+0 \\
7 \\
\end{array}$ & $1.79 \mathrm{E}+22$ & 14.9 & FCAB02 \\
\hline BM604 & M4-PCCVN & $\mathrm{C} 36 \mathrm{M}$ & $\mathrm{Fe}-13 \mathrm{Cr}-6 \mathrm{Al}-2 \mathrm{Mo}$ & 200 & $\begin{array}{c}\text { PTP A4 } \\
4\end{array}$ & $\begin{array}{c}1.08 \mathrm{E}+1 \\
5\end{array}$ & 8 & $\begin{array}{c}1.66 \mathrm{E}+0 \\
7\end{array}$ & $1.79 \mathrm{E}+22$ & 14.9 & FCAB02 \\
\hline BZM05 & M4-PCCVN & $\mathrm{C} 06 \mathrm{M}$ & $\mathrm{Fe}-10 \mathrm{Cr}-6 \mathrm{Al}-2 \mathrm{Mo}$ & 200 & $\begin{array}{c}\text { PTP D7 } \\
4 \\
\end{array}$ & $\begin{array}{c}1.08 \mathrm{E}+1 \\
5 \\
\end{array}$ & 4 & $\begin{array}{c}8.29 \mathrm{E}+0 \\
6 \\
\end{array}$ & $8.96 \mathrm{E}+21$ & 7.4 & FCAB01 \\
\hline BZM06 & M4-PCCVN & $\mathrm{C} 06 \mathrm{M}$ & Fe-10Cr-6Al-2Mo & 200 & $\begin{array}{c}\text { PTP D7 } \\
4\end{array}$ & $\begin{array}{c}1.08 \mathrm{E}+1 \\
5 \\
\end{array}$ & 4 & $\begin{array}{c}8.29 \mathrm{E}+0 \\
6 \\
\end{array}$ & $8.96 \mathrm{E}+21$ & 7.4 & FCAB01 \\
\hline BM605 & M4-PCCVN & $\mathrm{C} 36 \mathrm{M}$ & $\mathrm{Fe}-13 \mathrm{Cr}-6 \mathrm{Al}-2 \mathrm{Mo}$ & 200 & $\begin{array}{c}\text { PTP D7 } \\
4\end{array}$ & $\begin{array}{c}1.08 \mathrm{E}+1 \\
5 \\
\end{array}$ & 4 & $\begin{array}{c}8.29 \mathrm{E}+0 \\
6 \\
\end{array}$ & $8.96 \mathrm{E}+21$ & 7.4 & FCAB01 \\
\hline BM606 & M4-PCCVN & $\mathrm{C} 36 \mathrm{M}$ & $\mathrm{Fe}-13 \mathrm{Cr}-6 \mathrm{Al}-2 \mathrm{Mo}$ & 200 & $\begin{array}{c}\text { PTP D7 } \\
4 \\
\end{array}$ & $\begin{array}{c}1.08 \mathrm{E}+1 \\
5 \\
\end{array}$ & 4 & $\begin{array}{c}8.29 \mathrm{E}+0 \\
6 \\
\end{array}$ & $8.96 \mathrm{E}+21$ & 7.4 & FCAB01 \\
\hline BZM07 & M4-PCCVN & $\mathrm{C} 06 \mathrm{M}$ & $\mathrm{Fe}-10 \mathrm{Cr}-6 \mathrm{Al}-2 \mathrm{Mo}$ & 200 & $\begin{array}{c}\text { PTP A4 } \\
6 \\
\end{array}$ & $\begin{array}{c}1.10 \mathrm{E}+1 \\
5 \\
\end{array}$ & 8 & $\begin{array}{c}1.66 \mathrm{E}+0 \\
7 \\
\end{array}$ & $1.82 \mathrm{E}+22$ & 15.2 & FCAB02 \\
\hline BZM08 & M4-PCCVN & $\mathrm{C} 06 \mathrm{M}$ & $\mathrm{Fe}-10 \mathrm{Cr}-6 \mathrm{Al}-2 \mathrm{Mo}$ & 200 & $\begin{array}{c}\text { PTP A4 } \\
6 \\
\end{array}$ & $\begin{array}{c}1.10 \mathrm{E}+1 \\
5 \\
\end{array}$ & 8 & $\begin{array}{c}1.66 \mathrm{E}+0 \\
7 \\
\end{array}$ & $1.82 \mathrm{E}+22$ & 15.2 & FCAB02 \\
\hline BM607 & M4-PCCVN & $\mathrm{C} 36 \mathrm{M}$ & $\mathrm{Fe}-13 \mathrm{Cr}-6 \mathrm{Al}-2 \mathrm{Mo}$ & 200 & $\begin{array}{c}\text { PTP A4 } \\
6 \\
\end{array}$ & $\begin{array}{c}1.10 \mathrm{E}+1 \\
5 \\
\end{array}$ & 8 & $\begin{array}{c}1.66 \mathrm{E}+0 \\
7 \\
\end{array}$ & $1.82 \mathrm{E}+22$ & 15.2 & FCAB02 \\
\hline BM608 & M4-PCCVN & $\mathrm{C} 36 \mathrm{M}$ & $\mathrm{Fe}-13 \mathrm{Cr}-6 \mathrm{Al}-2 \mathrm{Mo}$ & 200 & $\begin{array}{c}\text { PTP A4 } \\
6 \\
\end{array}$ & $\begin{array}{c}1.10 \mathrm{E}+1 \\
5 \\
\end{array}$ & 8 & $\begin{array}{c}1.66 \mathrm{E}+0 \\
7 \\
\end{array}$ & $1.82 \mathrm{E}+22$ & 15.2 & FCAB02 \\
\hline BZM10 & M4-PCCVN & $\mathrm{C} 06 \mathrm{M}$ & $\mathrm{Fe}-10 \mathrm{Cr}-6 \mathrm{Al}-2 \mathrm{Mo}$ & 200 & $\begin{array}{c}\text { PTP A1 } \\
5 \\
\end{array}$ & $\begin{array}{c}1.04 \mathrm{E}+1 \\
5 \\
\end{array}$ & 4 & $\begin{array}{c}8.29 \mathrm{E}+0 \\
6 \\
\end{array}$ & $8.63 \mathrm{E}+21$ & 7.2 & FCAB01 \\
\hline BM609 & M4-PCCVN & $\mathrm{C} 36 \mathrm{M}$ & $\mathrm{Fe}-13 \mathrm{Cr}-6 \mathrm{Al}-2 \mathrm{Mo}$ & 200 & $\begin{array}{c}\text { PTP A1 } \\
5\end{array}$ & $\begin{array}{c}1.04 \mathrm{E}+1 \\
5\end{array}$ & 4 & $\begin{array}{c}8.29 \mathrm{E}+0 \\
6\end{array}$ & $8.63 \mathrm{E}+21$ & 7.2 & FCAB 01 \\
\hline BM610 & M4-PCCVN & $\mathrm{C} 36 \mathrm{M}$ & $\mathrm{Fe}-13 \mathrm{Cr}-6 \mathrm{Al}-2 \mathrm{Mo}$ & 200 & $\begin{array}{c}\text { PTP A1 } \\
5\end{array}$ & $\begin{array}{c}1.04 \mathrm{E}+1 \\
5\end{array}$ & 4 & $\begin{array}{c}8.29 \mathrm{E}+0 \\
6\end{array}$ & $8.63 \mathrm{E}+21$ & 7.2 & FCAB01 \\
\hline BZM11 & M4-PCCVN & $\mathrm{C} 06 \mathrm{M}$ & $\mathrm{Fe}-10 \mathrm{Cr}-6 \mathrm{Al}-2 \mathrm{Mo}$ & 200 & $\begin{array}{c}\text { PTP D1 } \\
6 \\
\end{array}$ & $\begin{array}{c}1.04 \mathrm{E}+1 \\
5 \\
\end{array}$ & 8 & $\begin{array}{c}1.66 \mathrm{E}+0 \\
7 \\
\end{array}$ & $1.73 \mathrm{E}+22$ & 14.3 & $\mathrm{FCAB} 02$ \\
\hline BZM12 & M4-PCCVN & $\mathrm{C} 06 \mathrm{M}$ & $\mathrm{Fe}-10 \mathrm{Cr}-6 \mathrm{Al}-2 \mathrm{Mo}$ & 200 & $\begin{array}{c}\text { PTP D1 } \\
6 \\
\end{array}$ & $\begin{array}{c}1.04 \mathrm{E}+1 \\
5 \\
\end{array}$ & 8 & $\begin{array}{c}1.66 \mathrm{E}+0 \\
7 \\
\end{array}$ & $1.73 \mathrm{E}+22$ & 14.3 & FCAB02 \\
\hline BM611 & M4-PCCVN & $\mathrm{C} 36 \mathrm{M}$ & $\mathrm{Fe}-13 \mathrm{Cr}-6 \mathrm{Al}-2 \mathrm{Mo}$ & 200 & $\begin{array}{c}\text { PTP D1 } \\
6\end{array}$ & $\begin{array}{c}1.04 \mathrm{E}+1 \\
5 \\
\end{array}$ & 8 & $\begin{array}{c}1.66 \mathrm{E}+0 \\
7 \\
\end{array}$ & $1.73 \mathrm{E}+22$ & 14.3 & FCAB02 \\
\hline BM612 & M4-PCCVN & $\mathrm{C} 36 \mathrm{M}$ & $\mathrm{Fe}-13 \mathrm{Cr}-6 \mathrm{Al}-2 \mathrm{Mo}$ & 200 & $\begin{array}{c}\text { PTP D1 } \\
6 \\
\end{array}$ & $\begin{array}{c}1.04 \mathrm{E}+1 \\
5 \\
\end{array}$ & 8 & $\begin{array}{c}1.66 \mathrm{E}+0 \\
7 \\
\end{array}$ & $1.73 \mathrm{E}+22$ & 14.3 & FCAB02 \\
\hline MF01 & SS-J2 & $\mathrm{C} 35 \mathrm{M}$ & $\mathrm{Fe}-13 \mathrm{Cr}-5 \mathrm{Al}-2 \mathrm{Mo}$ & 200 & $\begin{array}{c}\text { PTP D7 } \\
5 \\
\end{array}$ & $\begin{array}{c}1.08 \mathrm{E}+1 \\
5 \\
\end{array}$ & 1 & $2.1 \mathrm{E}+06$ & $2.2 \mathrm{E}+21$ & 1.9 & FCAT01 \\
\hline MF02 & SS-J2 & $\mathrm{C} 35 \mathrm{M}$ & $\mathrm{Fe}-13 \mathrm{Cr}-5 \mathrm{Al}-2 \mathrm{Mo}$ & 200 & $\begin{array}{c}\text { PTP D7 } \\
5 \\
\end{array}$ & $\begin{array}{c}1.08 \mathrm{E}+1 \\
5 \\
\end{array}$ & 1 & $2.1 \mathrm{E}+06$ & $2.2 \mathrm{E}+21$ & 1.9 & FCAT01 \\
\hline MF03 & SS-J2 & $\mathrm{C} 35 \mathrm{M}$ & $\mathrm{Fe}-13 \mathrm{Cr}-5 \mathrm{Al}-2 \mathrm{Mo}$ & 200 & $\begin{array}{c}\text { PTP D7 } \\
5 \\
\end{array}$ & $\begin{array}{c}1.08 \mathrm{E}+1 \\
5 \\
\end{array}$ & 1 & $2.1 \mathrm{E}+06$ & $2.2 \mathrm{E}+21$ & 1.9 & FCAT01 \\
\hline N501 & SS-J2 & $\mathrm{C} 35 \mathrm{MN}$ & $\mathrm{Fe}-13 \mathrm{Cr}-5 \mathrm{Al}-2 \mathrm{Mo}-1 \mathrm{Nb}$ & 200 & $\begin{array}{c}\text { PTP D7 } \\
5 \\
\end{array}$ & $\begin{array}{c}1.08 \mathrm{E}+1 \\
5 \\
\end{array}$ & 1 & $2.1 \mathrm{E}+06$ & $2.2 \mathrm{E}+21$ & 1.9 & FCAT01 \\
\hline $\mathrm{N} 502$ & SS-J2 & $\mathrm{C} 35 \mathrm{MN}$ & $\mathrm{Fe}-13 \mathrm{Cr}-5 \mathrm{Al}-2 \mathrm{Mo}-1 \mathrm{Nb}$ & 200 & $\begin{array}{c}\text { PTP D7 } \\
5 \\
\end{array}$ & $\begin{array}{c}1.08 \mathrm{E}+1 \\
5 \\
\end{array}$ & 1 & $2.1 \mathrm{E}+06$ & $2.2 \mathrm{E}+21$ & 1.9 & FCAT01 \\
\hline M601 & SS-J2 & $\mathrm{C} 36 \mathrm{M}$ & $\mathrm{Fe}-13 \mathrm{Cr}-6 \mathrm{Al}-2 \mathrm{Mo}$ & 200 & $\begin{array}{c}\text { PTP D7 } \\
5 \\
\end{array}$ & $\begin{array}{c}1.08 \mathrm{E}+1 \\
5 \\
\end{array}$ & 1 & $2.1 \mathrm{E}+06$ & $2.2 \mathrm{E}+21$ & 1.9 & FCAT01 \\
\hline M602 & SS-J2 & $\mathrm{C} 36 \mathrm{M}$ & $\mathrm{Fe}-13 \mathrm{Cr}-6 \mathrm{Al}-2 \mathrm{Mo}$ & 200 & $\begin{array}{c}\text { PTP D7 } \\
5 \\
\end{array}$ & $\begin{array}{c}1.08 \mathrm{E}+1 \\
5 \\
\end{array}$ & 1 & $2.1 \mathrm{E}+06$ & $2.2 \mathrm{E}+21$ & 1.9 & FCAT01 \\
\hline M603 & SS-J2 & $\mathrm{C} 36 \mathrm{M}$ & $\mathrm{Fe}-13 \mathrm{Cr}-6 \mathrm{Al}-2 \mathrm{Mo}$ & 200 & $\begin{array}{c}\text { PTP D7 } \\
5 \\
\end{array}$ & $\begin{array}{c}1.08 \mathrm{E}+1 \\
5\end{array}$ & 1 & $2.1 \mathrm{E}+06$ & $2.2 \mathrm{E}+21$ & 1.9 & FCAT01 \\
\hline MV01 & SS-J2 & $\mathrm{C} 37 \mathrm{M}$ & $\mathrm{Fe}-13 \mathrm{Cr}-7 \mathrm{Al}-2 \mathrm{Mo}$ & 200 & $\begin{array}{c}\text { PTP D7 } \\
5 \\
\end{array}$ & $\begin{array}{c}1.08 \mathrm{E}+1 \\
5 \\
\end{array}$ & 1 & $2.1 \mathrm{E}+06$ & $2.2 \mathrm{E}+21$ & 1.9 & FCAT01 \\
\hline MV02 & SS-J2 & $\mathrm{C} 37 \mathrm{M}$ & $\mathrm{Fe}-13 \mathrm{Cr}-7 \mathrm{Al}-2 \mathrm{Mo}$ & 200 & $\begin{array}{c}\text { PTP D7 } \\
5 \\
\end{array}$ & $\begin{array}{c}1.08 \mathrm{E}+1 \\
5 \\
\end{array}$ & 1 & $2.1 \mathrm{E}+06$ & $2.2 \mathrm{E}+21$ & 1.9 & FCAT01 \\
\hline
\end{tabular}




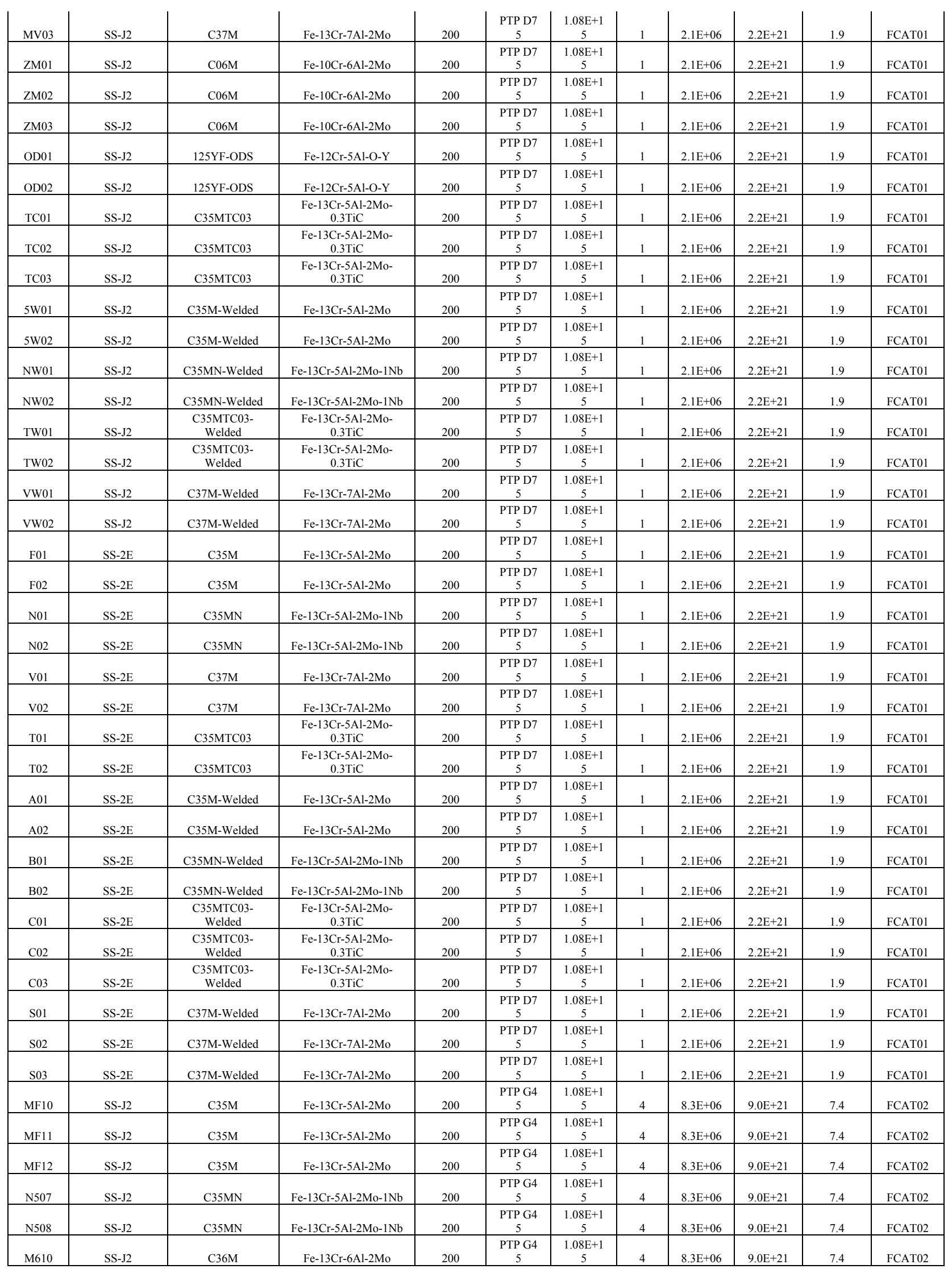




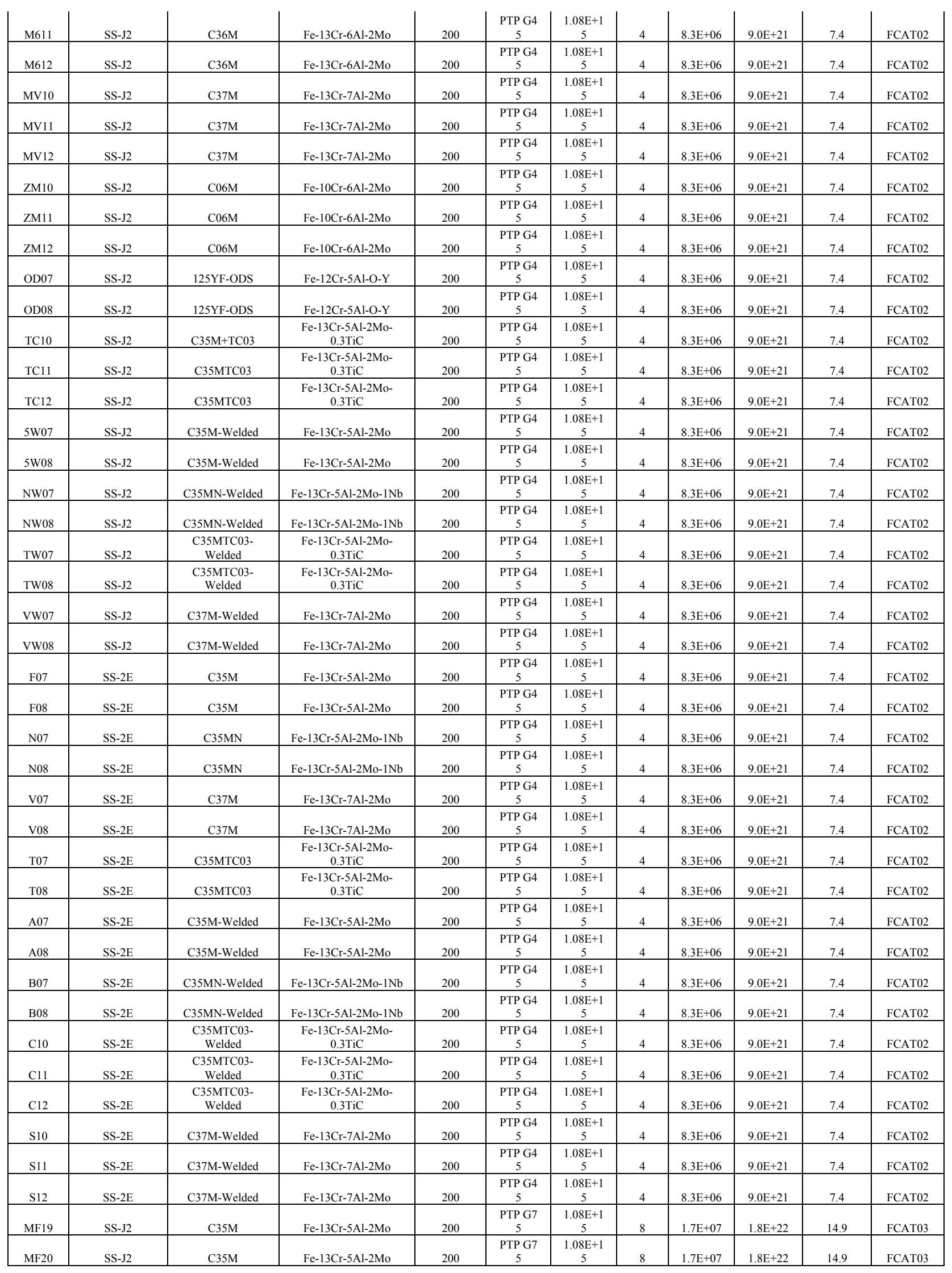




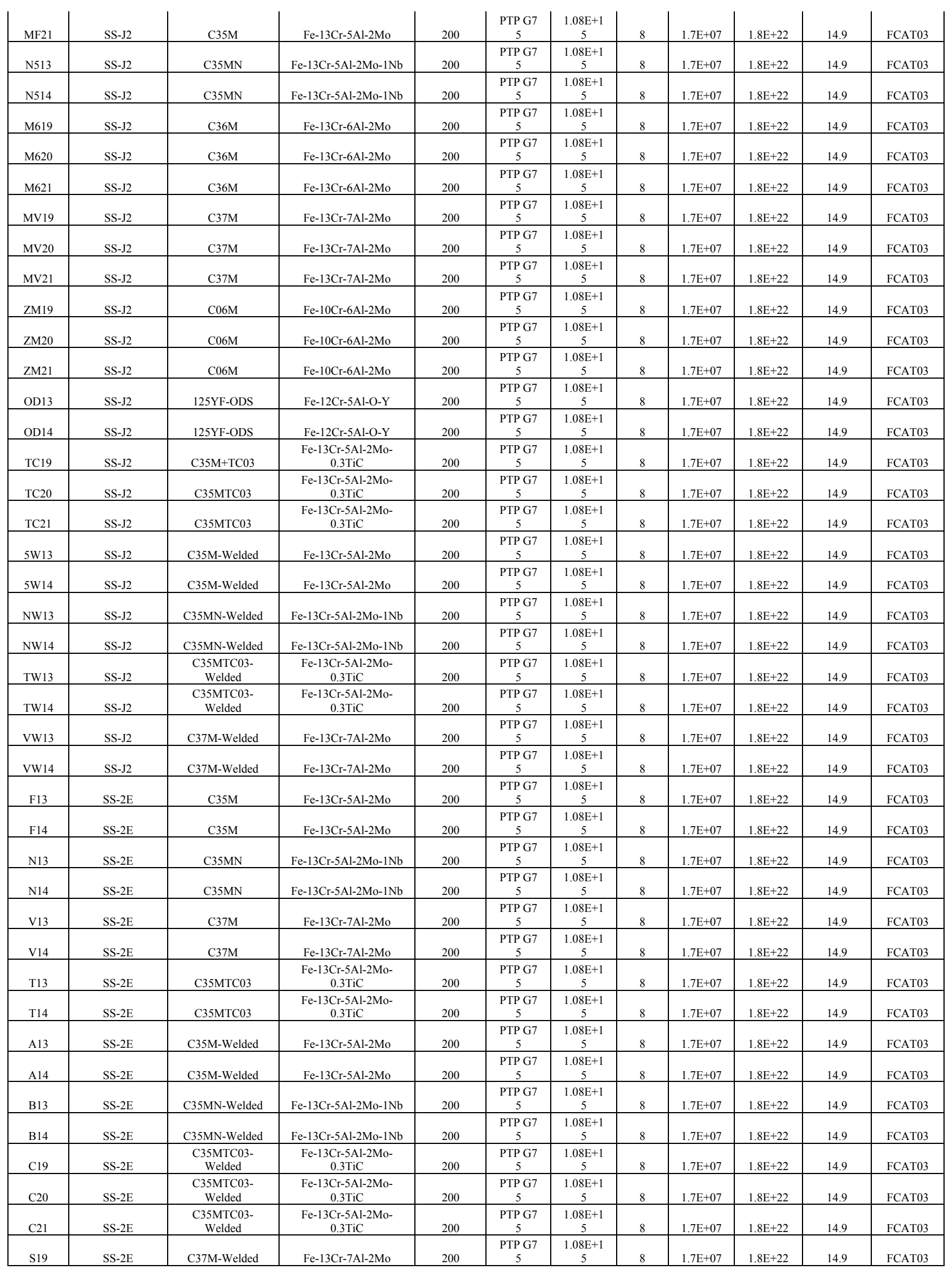




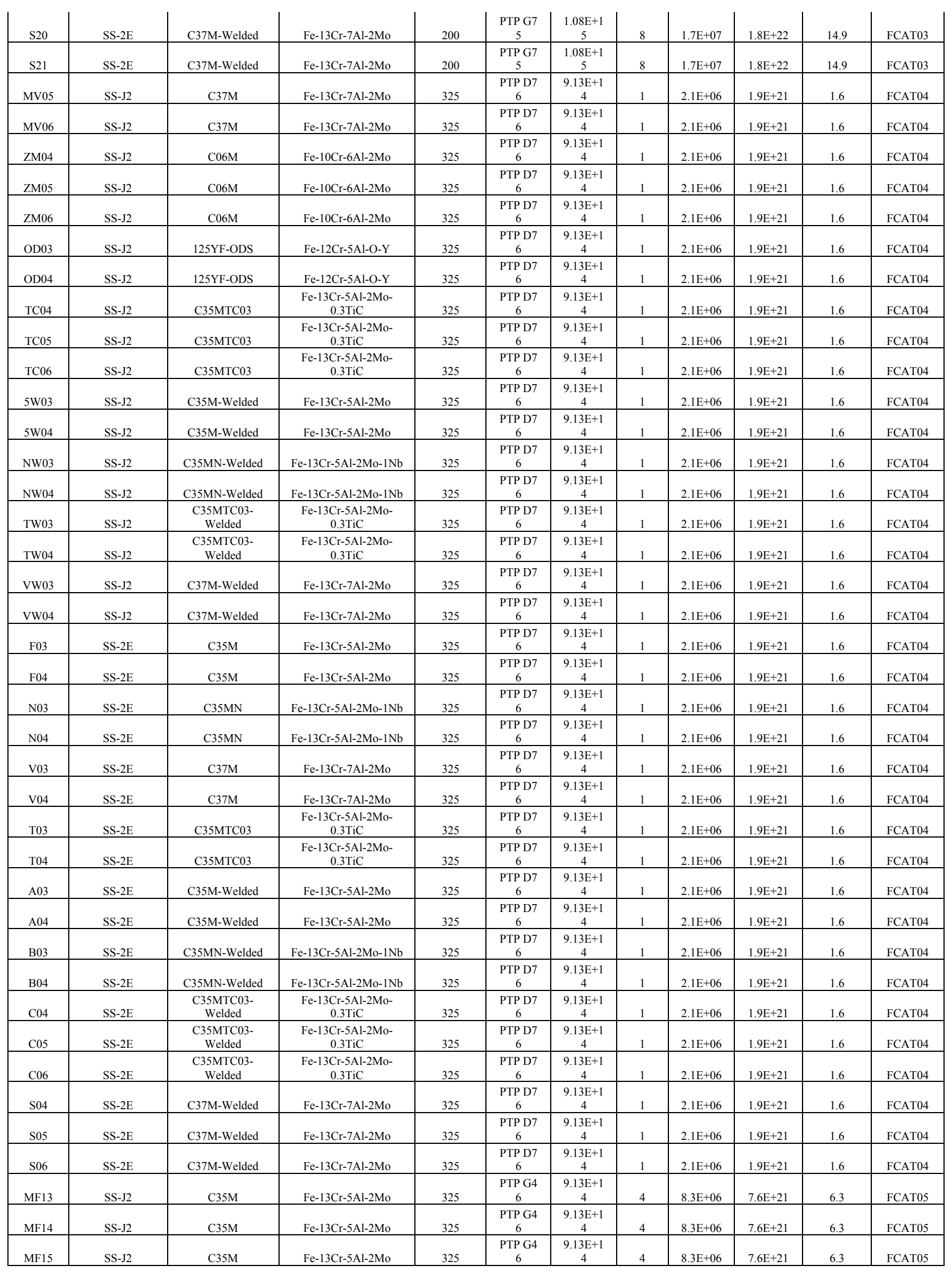




\begin{tabular}{|c|c|c|c|c|c|c|c|c|c|c|c|}
\hline N509 & SS-J2 & $\mathrm{C} 35 \mathrm{MN}$ & $\mathrm{Fe}-13 \mathrm{Cr}-5 \mathrm{Al}-2 \mathrm{Mo}-1 \mathrm{Nb}$ & 325 & $\begin{array}{l}\text { PTP G4 } \\
\quad 6\end{array}$ & $\begin{array}{c}9.13 \mathrm{E}+1 \\
4\end{array}$ & 4 & $8.3 \mathrm{E}+06$ & $7.6 \mathrm{E}+21$ & 6.3 & FCAT05 \\
\hline N510 & SS-J2 & $\mathrm{C} 35 \mathrm{MN}$ & Fe-13Cr-5Al-2Mo-1Nb & 325 & $\begin{array}{c}\text { PTP G4 } \\
\quad 6 \\
\end{array}$ & $\begin{array}{c}9.13 \mathrm{E}+1 \\
4\end{array}$ & 4 & $8.3 \mathrm{E}+06$ & $7.6 \mathrm{E}+21$ & 6.3 & FCAT05 \\
\hline M613 & SS-J2 & $\mathrm{C} 36 \mathrm{M}$ & $\mathrm{Fe}-13 \mathrm{Cr}-6 \mathrm{Al}-2 \mathrm{Mo}$ & 325 & $\begin{array}{c}\text { PTP G4 } \\
6 \\
\end{array}$ & $\begin{array}{c}9.13 \mathrm{E}+1 \\
4 \\
\end{array}$ & 4 & $8.3 \mathrm{E}+06$ & $7.6 \mathrm{E}+21$ & 6.3 & FCAT05 \\
\hline M614 & SS-J2 & $\mathrm{C} 36 \mathrm{M}$ & $\mathrm{Fe}-13 \mathrm{Cr}-6 \mathrm{Al}-2 \mathrm{Mo}$ & 325 & $\begin{array}{c}\text { PTP G4 } \\
6 \\
\end{array}$ & $\begin{array}{c}9.13 \mathrm{E}+1 \\
4\end{array}$ & 4 & $8.3 \mathrm{E}+06$ & $7.6 \mathrm{E}+21$ & 6.3 & FCAT05 \\
\hline M615 & SS-J2 & $\mathrm{C} 36 \mathrm{M}$ & $\mathrm{Fe}-13 \mathrm{Cr}-6 \mathrm{Al}-2 \mathrm{Mo}$ & 325 & $\begin{array}{c}\text { PTP G4 } \\
6 \\
\end{array}$ & $\begin{array}{c}9.13 \mathrm{E}+1 \\
4\end{array}$ & 4 & $8.3 \mathrm{E}+06$ & $7.6 \mathrm{E}+21$ & 6.3 & FCAT05 \\
\hline MV13 & SS-J2 & $\mathrm{C} 37 \mathrm{M}$ & $\mathrm{Fe}-13 \mathrm{Cr}-7 \mathrm{Al}-2 \mathrm{Mo}$ & 325 & $\begin{array}{c}\text { PTP G4 } \\
6 \\
\end{array}$ & $\begin{array}{c}9.13 \mathrm{E}+1 \\
4\end{array}$ & 4 & $8.3 \mathrm{E}+06$ & $7.6 \mathrm{E}+21$ & 6.3 & FCAT05 \\
\hline MV14 & SS-J2 & $\mathrm{C} 37 \mathrm{M}$ & $\mathrm{Fe}-13 \mathrm{Cr}-7 \mathrm{Al}-2 \mathrm{Mo}$ & 325 & $\begin{array}{c}\text { PTP G4 } \\
6 \\
\end{array}$ & $\begin{array}{c}9.13 \mathrm{E}+1 \\
4\end{array}$ & 4 & $8.3 \mathrm{E}+06$ & $7.6 \mathrm{E}+21$ & 6.3 & FCAT05 \\
\hline MV15 & SS-J2 & $\mathrm{C} 37 \mathrm{M}$ & $\mathrm{Fe}-13 \mathrm{Cr}-7 \mathrm{Al}-2 \mathrm{Mo}$ & 325 & $\begin{array}{c}\text { PTP G4 } \\
6 \\
\end{array}$ & $\begin{array}{c}9.13 \mathrm{E}+1 \\
4\end{array}$ & 4 & $8.3 \mathrm{E}+06$ & $7.6 \mathrm{E}+21$ & 6.3 & FCAT05 \\
\hline ZM13 & SS-J2 & $\mathrm{C} 06 \mathrm{M}$ & $\mathrm{Fe}-10 \mathrm{Cr}-6 \mathrm{Al}-2 \mathrm{Mo}$ & 325 & $\begin{array}{c}\text { PTP G4 } \\
\quad 6 \\
\end{array}$ & $\begin{array}{c}9.13 \mathrm{E}+1 \\
4\end{array}$ & 4 & $8.3 \mathrm{E}+06$ & $7.6 \mathrm{E}+21$ & 6.3 & FCAT05 \\
\hline ZM14 & SS-J2 & $\mathrm{C} 06 \mathrm{M}$ & $\mathrm{Fe}-10 \mathrm{Cr}-6 \mathrm{Al}-2 \mathrm{Mo}$ & 325 & $\begin{array}{c}\text { PTP G4 } \\
\quad 6 \\
\end{array}$ & $\begin{array}{c}9.13 \mathrm{E}+1 \\
4\end{array}$ & 4 & $8.3 \mathrm{E}+06$ & $7.6 \mathrm{E}+21$ & 6.3 & FCAT05 \\
\hline OD09 & SS-J2 & 125YF-ODS & $\mathrm{Fe}-12 \mathrm{Cr}-5 \mathrm{Al}-\mathrm{O}-\mathrm{Y}$ & 325 & $\begin{array}{c}\text { PTP G4 } \\
6 \\
\end{array}$ & $\begin{array}{c}9.13 \mathrm{E}+1 \\
4\end{array}$ & 4 & $8.3 \mathrm{E}+06$ & $7.6 \mathrm{E}+21$ & 6.3 & FCAT05 \\
\hline OD10 & SS-J2 & 125YF-ODS & $\mathrm{Fe}-12 \mathrm{Cr}-5 \mathrm{Al}-\mathrm{O}-\mathrm{Y}$ & 325 & $\begin{array}{c}\text { PTP G4 } \\
\quad 6 \\
\end{array}$ & $\begin{array}{c}9.13 \mathrm{E}+1 \\
4\end{array}$ & 4 & $8.3 \mathrm{E}+06$ & $7.6 \mathrm{E}+21$ & 6.3 & FCAT05 \\
\hline $\mathrm{TC} 13$ & SS-J2 & $\mathrm{C} 35 \mathrm{M}+\mathrm{TC} 03$ & $\begin{array}{c}\mathrm{Fe}-13 \mathrm{Cr}-5 \mathrm{Al}-2 \mathrm{Mo}- \\
0.3 \mathrm{TiC} \\
\end{array}$ & 325 & $\begin{array}{c}\text { PTP G4 } \\
\quad 6 \\
\end{array}$ & $\begin{array}{c}9.13 \mathrm{E}+1 \\
4\end{array}$ & 4 & $8.3 \mathrm{E}+06$ & $7.6 \mathrm{E}+21$ & 6.3 & FCAT05 \\
\hline $\mathrm{TC} 14$ & SS-J2 & C35MTC03 & $\begin{array}{c}\text { Fe-13Cr-5Al-2Mo- } \\
0.3 \mathrm{TiC} \\
\end{array}$ & 325 & $\begin{array}{c}\text { PTP G4 } \\
\quad 6 \\
\end{array}$ & $\begin{array}{c}9.13 \mathrm{E}+1 \\
4\end{array}$ & 4 & $8.3 \mathrm{E}+06$ & $7.6 \mathrm{E}+21$ & 6.3 & FCAT05 \\
\hline $\mathrm{TC} 15$ & SS-J2 & $\mathrm{C} 35 \mathrm{MTC} 03$ & $\begin{array}{c}\mathrm{Fe}-13 \mathrm{Cr}-5 \mathrm{Al}-2 \mathrm{Mo}- \\
0.3 \mathrm{TiC} \\
\end{array}$ & 325 & $\begin{array}{c}\text { PTP G4 } \\
6 \\
\end{array}$ & $\begin{array}{c}9.13 \mathrm{E}+1 \\
4\end{array}$ & 4 & $8.3 \mathrm{E}+06$ & $7.6 \mathrm{E}+21$ & 6.3 & FCAT05 \\
\hline 5W09 & SS-J2 & C35M-Welded & $\mathrm{Fe}-13 \mathrm{Cr}-5 \mathrm{Al}-2 \mathrm{Mo}$ & 325 & $\begin{array}{c}\text { PTP G4 } \\
\quad 6 \\
\end{array}$ & $\begin{array}{c}9.13 \mathrm{E}+1 \\
4\end{array}$ & 4 & $8.3 \mathrm{E}+06$ & $7.6 \mathrm{E}+21$ & 6.3 & FCAT05 \\
\hline $5 \mathrm{~W} 10$ & SS-J2 & C35M-Welded & $\mathrm{Fe}-13 \mathrm{Cr}-5 \mathrm{Al}-2 \mathrm{Mo}$ & 325 & $\begin{array}{c}\text { PTP G4 } \\
6 \\
\end{array}$ & $\begin{array}{c}9.13 \mathrm{E}+1 \\
4\end{array}$ & 4 & $8.3 \mathrm{E}+06$ & $7.6 \mathrm{E}+21$ & 6.3 & FCAT05 \\
\hline NW09 & SS-J2 & C35MN-Welded & $\mathrm{Fe}-13 \mathrm{Cr}-5 \mathrm{Al}-2 \mathrm{Mo}-1 \mathrm{Nb}$ & 325 & $\begin{array}{c}\text { PTP G4 } \\
\quad 6 \\
\end{array}$ & $\begin{array}{c}9.13 \mathrm{E}+1 \\
4\end{array}$ & 4 & $8.3 \mathrm{E}+06$ & $7.6 \mathrm{E}+21$ & 6.3 & FCAT05 \\
\hline NW10 & SS-J2 & C35MN-Welded & Fe-13Cr-5Al-2Mo- $1 \mathrm{Nb}$ & 325 & $\begin{array}{c}\text { PTP G4 } \\
6 \\
\end{array}$ & $\begin{array}{c}9.13 \mathrm{E}+1 \\
4\end{array}$ & 4 & $8.3 \mathrm{E}+06$ & $7.6 \mathrm{E}+21$ & 6.3 & FCAT05 \\
\hline VW09 & SS-J2 & C37M-Welded & $\mathrm{Fe}-13 \mathrm{Cr}-7 \mathrm{Al}-2 \mathrm{Mo}$ & 325 & $\begin{array}{c}\text { PTP G4 } \\
\quad 6 \\
\end{array}$ & $\begin{array}{c}9.13 \mathrm{E}+1 \\
4\end{array}$ & 4 & $8.3 \mathrm{E}+06$ & $7.6 \mathrm{E}+21$ & 6.3 & FCAT05 \\
\hline VW10 & SS-J2 & C37M-Welded & $\mathrm{Fe}-13 \mathrm{Cr}-7 \mathrm{Al}-2 \mathrm{Mo}$ & 325 & $\begin{array}{c}\text { PTP G4 } \\
6 \\
\end{array}$ & $\begin{array}{c}9.13 \mathrm{E}+1 \\
4 \\
\end{array}$ & 4 & $8.3 \mathrm{E}+06$ & $7.6 \mathrm{E}+21$ & 6.3 & FCAT05 \\
\hline F09 & SS-2E & $\mathrm{C} 35 \mathrm{M}$ & $\mathrm{Fe}-13 \mathrm{Cr}-5 \mathrm{Al}-2 \mathrm{Mo}$ & 325 & $\begin{array}{c}\text { PTP G4 } \\
\quad 6 \\
\end{array}$ & $\begin{array}{c}9.13 \mathrm{E}+1 \\
4\end{array}$ & 4 & $8.3 \mathrm{E}+06$ & $7.6 \mathrm{E}+21$ & 6.3 & FCAT05 \\
\hline F10 & SS-2E & $\mathrm{C} 35 \mathrm{M}$ & $\mathrm{Fe}-13 \mathrm{Cr}-5 \mathrm{Al}-2 \mathrm{Mo}$ & 325 & $\begin{array}{c}\text { PTP G4 } \\
\quad 6 \\
\end{array}$ & $\begin{array}{c}9.13 \mathrm{E}+1 \\
4\end{array}$ & 4 & $8.3 \mathrm{E}+06$ & $7.6 \mathrm{E}+21$ & 6.3 & FCAT05 \\
\hline N09 & SS-2E & $\mathrm{C} 35 \mathrm{MN}$ & Fe-13Cr-5Al-2Mo-1Nb & 325 & $\begin{array}{c}\text { PTP G4 } \\
\quad 6 \\
\end{array}$ & $\begin{array}{c}9.13 \mathrm{E}+1 \\
4\end{array}$ & 4 & $8.3 \mathrm{E}+06$ & $7.6 \mathrm{E}+21$ & 6.3 & FCAT05 \\
\hline N10 & SS-2E & $\mathrm{C} 35 \mathrm{MN}$ & $\mathrm{Fe}-13 \mathrm{Cr}-5 \mathrm{Al}-2 \mathrm{Mo}-1 \mathrm{Nb}$ & 325 & $\begin{array}{c}\text { PTP G4 } \\
\quad 6 \\
\end{array}$ & $\begin{array}{c}9.13 \mathrm{E}+1 \\
4\end{array}$ & 4 & $8.3 \mathrm{E}+06$ & $7.6 \mathrm{E}+21$ & 6.3 & FCAT05 \\
\hline V09 & SS-2E & $\mathrm{C} 37 \mathrm{M}$ & $\mathrm{Fe}-13 \mathrm{Cr}-7 \mathrm{Al}-2 \mathrm{Mo}$ & 325 & $\begin{array}{l}\text { PTP G4 } \\
6 \\
\end{array}$ & $\begin{array}{c}9.13 \mathrm{E}+1 \\
4\end{array}$ & 4 & $8.3 \mathrm{E}+06$ & $7.6 \mathrm{E}+21$ & 6.3 & FCAT05 \\
\hline V10 & SS-2E & $\mathrm{C} 37 \mathrm{M}$ & $\mathrm{Fe}-13 \mathrm{Cr}-7 \mathrm{Al}-2 \mathrm{Mo}$ & 325 & $\begin{array}{c}\text { PTP G4 } \\
\quad 6 \\
\end{array}$ & $\begin{array}{c}9.13 \mathrm{E}+1 \\
4\end{array}$ & 4 & $8.3 \mathrm{E}+06$ & $7.6 \mathrm{E}+21$ & 6.3 & FCAT05 \\
\hline T09 & SS-2E & C35MTC03 & $\begin{array}{c}\text { Fe-13Cr-5Al-2Mo- } \\
0.3 \mathrm{TiC} \\
\end{array}$ & 325 & $\begin{array}{c}\text { PTP G4 } \\
\quad 6 \\
\end{array}$ & $\begin{array}{c}9.13 \mathrm{E}+1 \\
4\end{array}$ & 4 & $8.3 \mathrm{E}+06$ & $7.6 \mathrm{E}+21$ & 6.3 & FCAT05 \\
\hline $\mathrm{T} 10$ & SS-2E & C35MTC03 & $\begin{array}{c}\text { Fe-13Cr-5Al-2Mo- } \\
0.3 \mathrm{TiC} \\
\end{array}$ & 325 & $\begin{array}{c}\text { PTP G4 } \\
\quad 6 \\
\end{array}$ & $\begin{array}{c}9.13 \mathrm{E}+1 \\
4 \\
\end{array}$ & 4 & $8.3 \mathrm{E}+06$ & $7.6 \mathrm{E}+21$ & 6.3 & FCAT05 \\
\hline $\mathrm{A} 09$ & SS-2E & C35M-Welded & $\mathrm{Fe}-13 \mathrm{Cr}-5 \mathrm{Al}-2 \mathrm{Mo}$ & 325 & $\begin{array}{c}\text { PTP G4 } \\
\quad 6 \\
\end{array}$ & $\begin{array}{c}9.13 \mathrm{E}+1 \\
4\end{array}$ & 4 & $8.3 \mathrm{E}+06$ & $7.6 \mathrm{E}+21$ & 6.3 & FCAT05 \\
\hline $\mathrm{A} 10$ & SS-2E & C35M-Welded & $\mathrm{Fe}-13 \mathrm{Cr}-5 \mathrm{Al}-2 \mathrm{Mo}$ & 325 & $\begin{array}{c}\text { PTP G4 } \\
\quad 6 \\
\end{array}$ & $\begin{array}{c}9.13 \mathrm{E}+1 \\
4\end{array}$ & 4 & $8.3 \mathrm{E}+06$ & $7.6 \mathrm{E}+21$ & 6.3 & FCAT05 \\
\hline B09 & SS-2E & C35MN-Welded & Fe-13Cr-5Al-2Mo- $1 \mathrm{Nb}$ & 325 & $\begin{array}{c}\text { PTP G4 } \\
\quad 6 \\
\end{array}$ & $\begin{array}{c}9.13 \mathrm{E}+1 \\
4\end{array}$ & 4 & $8.3 \mathrm{E}+06$ & $7.6 \mathrm{E}+21$ & 6.3 & FCAT05 \\
\hline $\mathrm{B} 10$ & SS-2E & C35MN-Welded & $\mathrm{Fe}-13 \mathrm{Cr}-5 \mathrm{Al}-2 \mathrm{Mo}-1 \mathrm{Nb}$ & 325 & $\begin{array}{c}\text { PTP G4 } \\
6 \\
\end{array}$ & $\begin{array}{c}9.13 \mathrm{E}+1 \\
4 \\
\end{array}$ & 4 & $8.3 \mathrm{E}+06$ & $7.6 \mathrm{E}+21$ & 6.3 & FCAT05 \\
\hline $\mathrm{C} 13$ & SS-2E & $\begin{array}{l}\text { C35MTC03- } \\
\text { Welded }\end{array}$ & $\begin{array}{c}\mathrm{Fe}-13 \mathrm{Cr}-5 \mathrm{Al}-2 \mathrm{Mo}- \\
0.3 \mathrm{TiC} \\
\end{array}$ & 325 & $\begin{array}{c}\text { PTP G4 } \\
6 \\
\end{array}$ & $\begin{array}{c}9.13 \mathrm{E}+1 \\
4\end{array}$ & 4 & $8.3 \mathrm{E}+06$ & $7.6 \mathrm{E}+21$ & 6.3 & FCAT05 \\
\hline $\mathrm{C} 14$ & SS-2E & $\begin{array}{c}\text { C35MTC03- } \\
\text { Welded }\end{array}$ & $\begin{array}{c}\mathrm{Fe}-13 \mathrm{Cr}-5 \mathrm{Al}-2 \mathrm{Mo}- \\
0.3 \mathrm{TiC} \\
\end{array}$ & 325 & $\begin{array}{c}\text { PTP G4 } \\
\quad 6 \\
\end{array}$ & $\begin{array}{c}9.13 \mathrm{E}+1 \\
4 \\
\end{array}$ & 4 & $8.3 \mathrm{E}+06$ & $7.6 \mathrm{E}+21$ & 6.3 & FCAT05 \\
\hline $\mathrm{C} 15$ & SS-2E & $\begin{array}{c}\text { C35MTC03- } \\
\text { Welded }\end{array}$ & $\begin{array}{c}\mathrm{Fe}-13 \mathrm{Cr}-5 \mathrm{Al}-2 \mathrm{Mo}- \\
0.3 \mathrm{TiC} \\
\end{array}$ & 325 & $\begin{array}{c}\text { PTP G4 } \\
\quad 6 \\
\end{array}$ & $\begin{array}{c}9.13 \mathrm{E}+1 \\
4\end{array}$ & 4 & $8.3 \mathrm{E}+06$ & $7.6 \mathrm{E}+21$ & 6.3 & FCAT05 \\
\hline $\mathrm{S} 13$ & SS-2E & C37M-Welded & $\mathrm{Fe}-13 \mathrm{Cr}-7 \mathrm{Al}-2 \mathrm{Mo}$ & 325 & $\begin{array}{c}\text { PTP G4 } \\
\quad 6 \\
\end{array}$ & $\begin{array}{c}9.13 \mathrm{E}+1 \\
4\end{array}$ & 4 & $8.3 \mathrm{E}+06$ & $7.6 \mathrm{E}+21$ & 6.3 & FCAT05 \\
\hline S14 & SS-2E & C37M-Welded & $\mathrm{Fe}-13 \mathrm{Cr}-7 \mathrm{Al}-2 \mathrm{Mo}$ & 325 & $\begin{array}{c}\text { PTP G4 } \\
6 \\
\end{array}$ & $\begin{array}{c}9.13 \mathrm{E}+1 \\
4 \\
\end{array}$ & 4 & $8.3 \mathrm{E}+06$ & $7.6 \mathrm{E}+21$ & 6.3 & FCAT05 \\
\hline
\end{tabular}




\begin{tabular}{|c|c|c|c|c|c|c|c|c|c|c|c|}
\hline $\mathrm{S} 15$ & SS-2E & C37M-Welded & $\mathrm{Fe}-13 \mathrm{Cr}-7 \mathrm{Al}-2 \mathrm{Mo}$ & 325 & $\begin{array}{c}\text { PTP G4 } \\
\quad 6 \\
\end{array}$ & $\begin{array}{c}9.13 \mathrm{E}+1 \\
4 \\
\end{array}$ & 4 & $8.3 \mathrm{E}+06$ & $7.6 \mathrm{E}+21$ & 6.3 & FCAT05 \\
\hline MF22 & SS-J2 & $\mathrm{C} 35 \mathrm{M}$ & $\mathrm{Fe}-13 \mathrm{Cr}-5 \mathrm{Al}-2 \mathrm{Mo}$ & 325 & $\begin{array}{c}\text { PTP G7 } \\
6 \\
\end{array}$ & $\begin{array}{c}9.13 \mathrm{E}+1 \\
4 \\
\end{array}$ & 8 & $1.7 \mathrm{E}+07$ & $1.5 \mathrm{E}+22$ & 12.6 & FCAT06 \\
\hline MF23 & SS-J2 & $\mathrm{C} 35 \mathrm{M}$ & $\mathrm{Fe}-13 \mathrm{Cr}-5 \mathrm{Al}-2 \mathrm{Mo}$ & 325 & $\begin{array}{l}\text { PTP G7 } \\
\quad 6 \\
\end{array}$ & $\begin{array}{c}9.13 \mathrm{E}+1 \\
4\end{array}$ & 8 & $1.7 \mathrm{E}+07$ & $1.5 \mathrm{E}+22$ & 12.6 & FCAT06 \\
\hline MF24 & SS-J2 & $\mathrm{C} 35 \mathrm{M}$ & $\mathrm{Fe}-13 \mathrm{Cr}-5 \mathrm{Al}-2 \mathrm{Mo}$ & 325 & $\begin{array}{c}\text { PTP G7 } \\
6 \\
\end{array}$ & $\begin{array}{c}9.13 \mathrm{E}+1 \\
4 \\
\end{array}$ & 8 & $1.7 \mathrm{E}+07$ & $1.5 \mathrm{E}+22$ & 12.6 & FCAT06 \\
\hline N515 & SS-J2 & $\mathrm{C} 35 \mathrm{MN}$ & $\mathrm{Fe}-13 \mathrm{Cr}-5 \mathrm{Al}-2 \mathrm{Mo}-1 \mathrm{Nb}$ & 325 & $\begin{array}{c}\text { PTP G7 } \\
6\end{array}$ & $\begin{array}{c}9.13 \mathrm{E}+1 \\
4\end{array}$ & 8 & $1.7 \mathrm{E}+07$ & $1.5 \mathrm{E}+22$ & 12.6 & FCAT06 \\
\hline N516 & SS-J2 & $\mathrm{C} 35 \mathrm{MN}$ & $\mathrm{Fe}-13 \mathrm{Cr}-5 \mathrm{Al}-2 \mathrm{Mo}-1 \mathrm{Nb}$ & 325 & $\begin{array}{c}\text { PTP G7 } \\
\quad 6 \\
\end{array}$ & $\begin{array}{c}9.13 \mathrm{E}+1 \\
4 \\
\end{array}$ & 8 & $1.7 \mathrm{E}+07$ & $1.5 \mathrm{E}+22$ & 12.6 & FCAT06 \\
\hline M622 & SS-J2 & $\mathrm{C} 36 \mathrm{M}$ & $\mathrm{Fe}-13 \mathrm{Cr}-6 \mathrm{Al}-2 \mathrm{Mo}$ & 325 & $\begin{array}{c}\text { PTP G7 } \\
6 \\
\end{array}$ & $\begin{array}{c}9.13 \mathrm{E}+1 \\
4 \\
\end{array}$ & 8 & $1.7 \mathrm{E}+07$ & $1.5 \mathrm{E}+22$ & 12.6 & FCAT06 \\
\hline M623 & SS-J2 & $\mathrm{C} 36 \mathrm{M}$ & $\mathrm{Fe}-13 \mathrm{Cr}-6 \mathrm{Al}-2 \mathrm{Mo}$ & 325 & $\begin{array}{c}\text { PTP G7 } \\
6 \\
\end{array}$ & $\begin{array}{c}9.13 \mathrm{E}+1 \\
4 \\
\end{array}$ & 8 & $1.7 \mathrm{E}+07$ & $1.5 \mathrm{E}+22$ & 12.6 & FCAT06 \\
\hline M624 & SS-J2 & $\mathrm{C} 36 \mathrm{M}$ & $\mathrm{Fe}-13 \mathrm{Cr}-6 \mathrm{Al}-2 \mathrm{Mo}$ & 325 & $\begin{array}{c}\text { PTP G7 } \\
6\end{array}$ & $\begin{array}{c}9.13 \mathrm{E}+1 \\
4\end{array}$ & 8 & $1.7 \mathrm{E}+07$ & $1.5 \mathrm{E}+22$ & 12.6 & FCAT06 \\
\hline MV22 & SS-J2 & $\mathrm{C} 37 \mathrm{M}$ & $\mathrm{Fe}-13 \mathrm{Cr}-7 \mathrm{Al}-2 \mathrm{Mo}$ & 325 & $\begin{array}{c}\text { PTP G7 } \\
6 \\
\end{array}$ & $\begin{array}{c}9.13 \mathrm{E}+1 \\
4\end{array}$ & 8 & $1.7 \mathrm{E}+07$ & $1.5 \mathrm{E}+22$ & 12.6 & FCAT06 \\
\hline MV23 & SS-J2 & $\mathrm{C} 37 \mathrm{M}$ & $\mathrm{Fe}-13 \mathrm{Cr}-7 \mathrm{Al}-2 \mathrm{Mo}$ & 325 & $\begin{array}{c}\text { PTP G7 } \\
\quad 6 \\
\end{array}$ & $\begin{array}{c}9.13 \mathrm{E}+1 \\
4 \\
\end{array}$ & 8 & $1.7 \mathrm{E}+07$ & $1.5 \mathrm{E}+22$ & 12.6 & FCAT06 \\
\hline MV24 & SS-J2 & $\mathrm{C} 37 \mathrm{M}$ & $\mathrm{Fe}-13 \mathrm{Cr}-7 \mathrm{Al}-2 \mathrm{Mo}$ & 325 & $\begin{array}{c}\text { PTP G7 } \\
\quad 6 \\
\end{array}$ & $\begin{array}{c}9.13 \mathrm{E}+1 \\
4 \\
\end{array}$ & 8 & $1.7 \mathrm{E}+07$ & $1.5 \mathrm{E}+22$ & 12.6 & FCAT06 \\
\hline ZM22 & SS-J2 & $\mathrm{C} 06 \mathrm{M}$ & $\mathrm{Fe}-10 \mathrm{Cr}-6 \mathrm{Al}-2 \mathrm{Mo}$ & 325 & $\begin{array}{l}\text { PTP G7 } \\
\quad 6 \\
\end{array}$ & $\begin{array}{c}9.13 \mathrm{E}+1 \\
4\end{array}$ & 8 & $1.7 \mathrm{E}+07$ & $1.5 \mathrm{E}+22$ & 12.6 & FCAT06 \\
\hline ZM23 & SS-J2 & $\mathrm{C} 06 \mathrm{M}$ & $\mathrm{Fe}-10 \mathrm{Cr}-6 \mathrm{Al}-2 \mathrm{Mo}$ & 325 & $\begin{array}{l}\text { PTP G7 } \\
\quad 6 \\
\end{array}$ & $\begin{array}{c}9.13 \mathrm{E}+1 \\
4\end{array}$ & 8 & $1.7 \mathrm{E}+07$ & $1.5 \mathrm{E}+22$ & 12.6 & FCAT06 \\
\hline ZM24 & SS-J2 & $\mathrm{C} 06 \mathrm{M}$ & $\mathrm{Fe}-10 \mathrm{Cr}-6 \mathrm{Al}-2 \mathrm{Mo}$ & 325 & $\begin{array}{l}\text { PTP G7 } \\
\quad 6 \\
\end{array}$ & $\begin{array}{c}9.13 \mathrm{E}+1 \\
4\end{array}$ & 8 & $1.7 \mathrm{E}+07$ & $1.5 \mathrm{E}+22$ & 12.6 & FCAT06 \\
\hline OD15 & SS-J2 & 125YF-ODS & $\mathrm{Fe}-12 \mathrm{Cr}-5 \mathrm{Al}-\mathrm{O}-\mathrm{Y}$ & 325 & $\begin{array}{l}\text { PTP G7 } \\
\quad 6 \\
\end{array}$ & $\begin{array}{c}9.13 \mathrm{E}+1 \\
4\end{array}$ & 8 & $1.7 \mathrm{E}+07$ & $1.5 \mathrm{E}+22$ & 12.6 & FCAT06 \\
\hline OD16 & SS-J2 & $125 \mathrm{YF}-\mathrm{ODS}$ & $\mathrm{Fe}-12 \mathrm{Cr}-5 \mathrm{Al}-\mathrm{O}-\mathrm{Y}$ & 325 & $\begin{array}{l}\text { PTP G7 } \\
\quad 6 \\
\end{array}$ & $\begin{array}{c}9.13 \mathrm{E}+1 \\
4 \\
\end{array}$ & 8 & $1.7 \mathrm{E}+07$ & $1.5 \mathrm{E}+22$ & 12.6 & FCAT06 \\
\hline $\mathrm{TC} 22$ & SS-J2 & $\mathrm{C} 35 \mathrm{M}+\mathrm{TC} 03$ & $\begin{array}{c}\text { Fe-13Cr-5Al-2Mo- } \\
0.3 \mathrm{TiC} \\
\end{array}$ & 325 & $\begin{array}{l}\text { PTP G7 } \\
\quad 6 \\
\end{array}$ & $\begin{array}{c}9.13 \mathrm{E}+1 \\
4\end{array}$ & 8 & $1.7 \mathrm{E}+07$ & $1.5 \mathrm{E}+22$ & 12.6 & FCAT06 \\
\hline $\mathrm{TC} 23$ & SS-J2 & $\mathrm{C} 35 \mathrm{MTC} 03$ & $\begin{array}{c}\text { Fe-13Cr-5Al-2Mo- } \\
0.3 \mathrm{TiC} \\
\end{array}$ & 325 & $\begin{array}{l}\text { PTP G7 } \\
\quad 6 \\
\end{array}$ & $\begin{array}{c}9.13 \mathrm{E}+1 \\
4 \\
\end{array}$ & 8 & $1.7 \mathrm{E}+07$ & $1.5 \mathrm{E}+22$ & 12.6 & FCAT06 \\
\hline $\mathrm{TC} 24$ & SS-J2 & $\mathrm{C} 35 \mathrm{MTC} 03$ & $\begin{array}{c}\mathrm{Fe}-13 \mathrm{Cr}-5 \mathrm{Al}-2 \mathrm{Mo}- \\
0.3 \mathrm{TiC} \\
\end{array}$ & 325 & $\begin{array}{l}\text { PTP G7 } \\
\quad 6 \\
\end{array}$ & $\begin{array}{c}9.13 \mathrm{E}+1 \\
4\end{array}$ & 8 & $1.7 \mathrm{E}+07$ & $1.5 \mathrm{E}+22$ & 12.6 & FCAT06 \\
\hline $5 \mathrm{~W} 15$ & SS-J2 & C35M-Welded & $\mathrm{Fe}-13 \mathrm{Cr}-5 \mathrm{Al}-2 \mathrm{Mo}$ & 325 & $\begin{array}{l}\text { PTP G7 } \\
6 \\
\end{array}$ & $\begin{array}{c}9.13 \mathrm{E}+1 \\
4 \\
\end{array}$ & 8 & $1.7 \mathrm{E}+07$ & $1.5 \mathrm{E}+22$ & 12.6 & FCAT06 \\
\hline $5 \mathrm{~W} 16$ & SS-J2 & C35M-Welded & Fe-13Cr-5Al-2Mo & 325 & $\begin{array}{l}\text { PTP G7 } \\
\quad 6 \\
\end{array}$ & $\begin{array}{c}9.13 \mathrm{E}+1 \\
4\end{array}$ & 8 & $1.7 \mathrm{E}+07$ & $1.5 \mathrm{E}+22$ & 12.6 & FCAT06 \\
\hline NW15 & SS-J2 & C35MN-Welded & Fe-13Cr-5Al-2Mo-1Nb & 325 & $\begin{array}{c}\text { PTP G7 } \\
\quad 6 \\
\end{array}$ & $\begin{array}{c}9.13 \mathrm{E}+1 \\
4 \\
\end{array}$ & 8 & $1.7 \mathrm{E}+07$ & $1.5 \mathrm{E}+22$ & 12.6 & FCAT06 \\
\hline NW16 & SS-J2 & C35MN-Welded & $\mathrm{Fe}-13 \mathrm{Cr}-5 \mathrm{Al}-2 \mathrm{Mo}-1 \mathrm{Nb}$ & 325 & $\begin{array}{l}\text { PTP G7 } \\
6 \\
\end{array}$ & $\begin{array}{c}9.13 \mathrm{E}+1 \\
4 \\
\end{array}$ & 8 & $1.7 \mathrm{E}+07$ & $1.5 \mathrm{E}+22$ & 12.6 & FCAT06 \\
\hline TW15 & SS-J2 & $\begin{array}{l}\text { C35MTC03- } \\
\text { Welded }\end{array}$ & $\begin{array}{c}\text { Fe-13Cr-5Al-2Mo- } \\
0.3 \mathrm{TiC} \\
\end{array}$ & 325 & $\begin{array}{l}\text { PTP G7 } \\
\quad 6 \\
\end{array}$ & $\begin{array}{c}9.13 \mathrm{E}+1 \\
4\end{array}$ & 8 & $1.7 \mathrm{E}+07$ & $1.5 \mathrm{E}+22$ & 12.6 & FCAT06 \\
\hline TW16 & SS-J2 & $\begin{array}{c}\text { C35MTC03- } \\
\text { Welded }\end{array}$ & $\begin{array}{c}\text { Fe-13Cr-5Al-2Mo- } \\
0.3 \mathrm{TiC} \\
\end{array}$ & 325 & $\begin{array}{c}\text { PTP G7 } \\
6 \\
\end{array}$ & $\begin{array}{c}9.13 \mathrm{E}+1 \\
4 \\
\end{array}$ & 8 & $1.7 \mathrm{E}+07$ & $1.5 \mathrm{E}+22$ & 12.6 & FCAT06 \\
\hline VW15 & SS-J2 & C37M-Welded & $\mathrm{Fe}-13 \mathrm{Cr}-7 \mathrm{Al}-2 \mathrm{Mo}$ & 325 & $\begin{array}{l}\text { PTP G7 } \\
\quad 6 \\
\end{array}$ & $\begin{array}{c}9.13 \mathrm{E}+1 \\
4\end{array}$ & 8 & $1.7 \mathrm{E}+07$ & $1.5 \mathrm{E}+22$ & 12.6 & FCAT06 \\
\hline VW16 & SS-J2 & C37M-Welded & $\mathrm{Fe}-13 \mathrm{Cr}-7 \mathrm{Al}-2 \mathrm{Mo}$ & 325 & $\begin{array}{l}\text { PTP G7 } \\
\quad 6 \\
\end{array}$ & $\begin{array}{c}9.13 \mathrm{E}+1 \\
4\end{array}$ & 8 & $1.7 \mathrm{E}+07$ & $1.5 \mathrm{E}+22$ & 12.6 & FCAT06 \\
\hline F15 & SS-2E & $\mathrm{C} 35 \mathrm{M}$ & $\mathrm{Fe}-13 \mathrm{Cr}-5 \mathrm{Al}-2 \mathrm{Mo}$ & 325 & $\begin{array}{l}\text { PTP G7 } \\
\quad 6 \\
\end{array}$ & $\begin{array}{c}9.13 \mathrm{E}+1 \\
4 \\
\end{array}$ & 8 & $1.7 \mathrm{E}+07$ & $1.5 \mathrm{E}+22$ & 12.6 & FCAT06 \\
\hline F16 & SS-2E & $\mathrm{C} 35 \mathrm{M}$ & Fe-13Cr-5Al-2Mo & 325 & $\begin{array}{l}\text { PTP G7 } \\
6 \\
\end{array}$ & $\begin{array}{c}9.13 \mathrm{E}+1 \\
4\end{array}$ & 8 & $1.7 \mathrm{E}+07$ & $1.5 \mathrm{E}+22$ & 12.6 & FCAT06 \\
\hline N15 & SS-2E & $\mathrm{C} 35 \mathrm{MN}$ & $\mathrm{Fe}-13 \mathrm{Cr}-5 \mathrm{Al}-2 \mathrm{Mo}-1 \mathrm{Nb}$ & 325 & $\begin{array}{l}\text { PTP G7 } \\
\quad 6 \\
\end{array}$ & $\begin{array}{c}9.13 \mathrm{E}+1 \\
4\end{array}$ & 8 & $1.7 \mathrm{E}+07$ & $1.5 \mathrm{E}+22$ & 12.6 & FCAT06 \\
\hline N16 & SS-2E & $\mathrm{C} 35 \mathrm{MN}$ & Fe-13Cr-5Al-2Mo-1Nb & 325 & $\begin{array}{c}\text { PTP G7 } \\
6 \\
\end{array}$ & $\begin{array}{c}9.13 \mathrm{E}+1 \\
4 \\
\end{array}$ & 8 & $1.7 \mathrm{E}+07$ & $1.5 \mathrm{E}+22$ & 12.6 & FCAT06 \\
\hline V15 & SS-2E & $\mathrm{C} 37 \mathrm{M}$ & $\mathrm{Fe}-13 \mathrm{Cr}-7 \mathrm{Al}-2 \mathrm{Mo}$ & 325 & $\begin{array}{c}\text { PTP G7 } \\
6 \\
\end{array}$ & $\begin{array}{c}9.13 \mathrm{E}+1 \\
4 \\
\end{array}$ & 8 & $1.7 \mathrm{E}+07$ & $1.5 \mathrm{E}+22$ & 12.6 & FCAT06 \\
\hline V16 & SS-2E & $\mathrm{C} 37 \mathrm{M}$ & $\mathrm{Fe}-13 \mathrm{Cr}-7 \mathrm{Al}-2 \mathrm{Mo}$ & 325 & $\begin{array}{c}\text { PTP G7 } \\
\quad 6 \\
\end{array}$ & $\begin{array}{c}9.13 \mathrm{E}+1 \\
4 \\
\end{array}$ & 8 & $1.7 \mathrm{E}+07$ & $1.5 \mathrm{E}+22$ & 12.6 & FCAT06 \\
\hline $\mathrm{T} 15$ & SS-2E & $\mathrm{C} 35 \mathrm{MTC} 03$ & $\begin{array}{c}\mathrm{Fe}-13 \mathrm{Cr}-5 \mathrm{Al}-2 \mathrm{Mo}- \\
0.3 \mathrm{TiC} \\
\end{array}$ & 325 & $\begin{array}{c}\text { PTP G7 } \\
\quad 6 \\
\end{array}$ & $\begin{array}{c}9.13 \mathrm{E}+1 \\
4 \\
\end{array}$ & 8 & $1.7 \mathrm{E}+07$ & $1.5 \mathrm{E}+22$ & 12.6 & FCAT06 \\
\hline $\mathrm{T} 16$ & SS-2E & $\mathrm{C} 35 \mathrm{MTC} 03$ & $\begin{array}{c}\mathrm{Fe}-13 \mathrm{Cr}-5 \mathrm{Al}-2 \mathrm{Mo}- \\
0.3 \mathrm{TiC} \\
\end{array}$ & 325 & $\begin{array}{l}\text { PTP G7 } \\
\quad 6 \\
\end{array}$ & $\begin{array}{c}9.13 \mathrm{E}+1 \\
4 \\
\end{array}$ & 8 & $1.7 \mathrm{E}+07$ & $1.5 \mathrm{E}+22$ & 12.6 & FCAT06 \\
\hline $\mathrm{A} 15$ & SS-2E & C35M-Welded & $\mathrm{Fe}-13 \mathrm{Cr}-5 \mathrm{Al}-2 \mathrm{Mo}$ & 325 & $\begin{array}{l}\text { PTP G7 } \\
\quad 6 \\
\end{array}$ & $\begin{array}{c}9.13 \mathrm{E}+1 \\
4\end{array}$ & 8 & $1.7 \mathrm{E}+07$ & $1.5 \mathrm{E}+22$ & 12.6 & FCAT06 \\
\hline $\mathrm{A} 16$ & SS-2E & C35M-Welded & $\mathrm{Fe}-13 \mathrm{Cr}-5 \mathrm{Al}-2 \mathrm{Mo}$ & 325 & $\begin{array}{l}\text { PTP G7 } \\
\quad 6 \\
\end{array}$ & $\begin{array}{c}9.13 \mathrm{E}+1 \\
4\end{array}$ & 8 & $1.7 \mathrm{E}+07$ & $1.5 \mathrm{E}+22$ & 12.6 & FCAT06 \\
\hline B15 & SS-2E & C35MN-Welded & $\mathrm{Fe}-13 \mathrm{Cr}-5 \mathrm{Al}-2 \mathrm{Mo}-1 \mathrm{Nb}$ & 325 & $\begin{array}{l}\text { PTP G7 } \\
\quad 6 \\
\end{array}$ & $\begin{array}{c}9.13 \mathrm{E}+1 \\
4\end{array}$ & 8 & $1.7 \mathrm{E}+07$ & $1.5 \mathrm{E}+22$ & 12.6 & FCAT06 \\
\hline B16 & SS-2E & C35MN-Welded & $\mathrm{Fe}-13 \mathrm{Cr}-5 \mathrm{Al}-2 \mathrm{Mo}-1 \mathrm{Nb}$ & 325 & $\begin{array}{c}\text { PTP G7 } \\
6 \\
\end{array}$ & $\begin{array}{c}9.13 \mathrm{E}+1 \\
4 \\
\end{array}$ & 8 & $1.7 \mathrm{E}+07$ & $1.5 \mathrm{E}+22$ & 12.6 & FCAT06 \\
\hline $\mathrm{C} 22$ & SS-2E & $\begin{array}{l}\text { C35MTC03- } \\
\text { Welded }\end{array}$ & $\begin{array}{c}\mathrm{Fe}-13 \mathrm{Cr}-5 \mathrm{Al}-2 \mathrm{Mo}- \\
0.3 \mathrm{TiC} \\
\end{array}$ & 325 & $\begin{array}{c}\text { PTP G7 } \\
6 \\
\end{array}$ & $\begin{array}{c}9.13 \mathrm{E}+1 \\
4 \\
\end{array}$ & 8 & $1.7 \mathrm{E}+07$ & $1.5 \mathrm{E}+22$ & 12.6 & FCAT06 \\
\hline
\end{tabular}




\begin{tabular}{|c|c|c|c|c|c|c|c|c|c|c|c|}
\hline $\mathrm{C} 23$ & SS-2E & $\begin{array}{l}\text { C35MTC03- } \\
\text { Welded }\end{array}$ & $\begin{array}{c}\mathrm{Fe}-13 \mathrm{Cr}-5 \mathrm{Al}-2 \mathrm{Mo}- \\
0.3 \mathrm{TiC}\end{array}$ & 325 & $\begin{array}{c}\text { PTP G7 } \\
6\end{array}$ & $\begin{array}{c}9.13 \mathrm{E}+1 \\
4\end{array}$ & 8 & $1.7 \mathrm{E}+07$ & $1.5 \mathrm{E}+22$ & 12.6 & FCAT06 \\
\hline $\mathrm{C} 24$ & SS-2E & $\begin{array}{l}\text { C35MTC03- } \\
\text { Welded }\end{array}$ & $\begin{array}{c}\mathrm{Fe}-13 \mathrm{Cr}-5 \mathrm{Al}-2 \mathrm{Mo}- \\
0.3 \mathrm{TiC} \\
\end{array}$ & 325 & $\begin{array}{c}\text { PTP G7 } \\
6 \\
\end{array}$ & $\begin{array}{c}9.13 \mathrm{E}+1 \\
4\end{array}$ & 8 & $1.7 \mathrm{E}+07$ & $1.5 \mathrm{E}+22$ & 12.6 & FCAT06 \\
\hline S22 & SS-2E & C37M-Welded & Fe-13Cr-7Al-2Mo & 325 & $\begin{array}{c}\text { PTP G7 } \\
6 \\
\end{array}$ & $\begin{array}{c}9.13 \mathrm{E}+1 \\
4 \\
\end{array}$ & 8 & $1.7 \mathrm{E}+07$ & $1.5 \mathrm{E}+22$ & 12.6 & FCAT06 \\
\hline $\mathrm{S} 23$ & SS-2E & C37M-Welded & Fe-13Cr-7Al-2Mo & 325 & $\begin{array}{c}\text { PTP G7 } \\
6 \\
\end{array}$ & $\begin{array}{c}9.13 \mathrm{E}+1 \\
4\end{array}$ & 8 & $1.7 \mathrm{E}+07$ & $1.5 \mathrm{E}+22$ & 12.6 & FCAT06 \\
\hline S24 & SS-2E & C37M-Welded & Fe-13Cr-7Al-2Mo & 325 & $\begin{array}{c}\text { PTP G7 } \\
6\end{array}$ & $\begin{array}{c}9.13 \mathrm{E}+1 \\
4\end{array}$ & 8 & $1.7 \mathrm{E}+07$ & $1.5 \mathrm{E}+22$ & 12.6 & FCAT06 \\
\hline MF07 & SS-J2 & $\mathrm{C} 35 \mathrm{M}$ & $\mathrm{Fe}-13 \mathrm{Cr}-5 \mathrm{Al}-2 \mathrm{Mo}$ & 550 & $\begin{array}{c}\text { PTP D7 } \\
5\end{array}$ & $\begin{array}{c}1.08 \mathrm{E}+1 \\
5 \\
\end{array}$ & 1 & $2.1 \mathrm{E}+06$ & $2.2 \mathrm{E}+21$ & 1.9 & FCAT04 \\
\hline MF08 & SS-J2 & $\mathrm{C} 35 \mathrm{M}$ & $\mathrm{Fe}-13 \mathrm{Cr}-5 \mathrm{Al}-2 \mathrm{Mo}$ & 550 & $\begin{array}{c}\text { PTP D7 } \\
5\end{array}$ & $\begin{array}{c}1.08 \mathrm{E}+1 \\
5 \\
\end{array}$ & 1 & $2.1 \mathrm{E}+06$ & $2.2 \mathrm{E}+21$ & 1.9 & FCAT04 \\
\hline MF09 & SS-J2 & $\mathrm{C} 35 \mathrm{M}$ & $\mathrm{Fe}-13 \mathrm{Cr}-5 \mathrm{Al}-2 \mathrm{Mo}$ & 550 & $\begin{array}{c}\text { PTP D7 } \\
5\end{array}$ & $\begin{array}{c}1.08 \mathrm{E}+1 \\
5\end{array}$ & 1 & $2.1 \mathrm{E}+06$ & $2.2 \mathrm{E}+21$ & 1.9 & FCAT04 \\
\hline N505 & SS-J2 & $\mathrm{C} 35 \mathrm{MN}$ & $\mathrm{Fe}-13 \mathrm{Cr}-5 \mathrm{Al}-2 \mathrm{Mo}-1 \mathrm{Nb}$ & 550 & $\begin{array}{c}\text { PTP D7 } \\
5\end{array}$ & $\begin{array}{c}1.08 \mathrm{E}+1 \\
5\end{array}$ & 1 & $2.1 \mathrm{E}+06$ & $2.2 \mathrm{E}+21$ & 1.9 & FCAT04 \\
\hline N506 & SS-J2 & $\mathrm{C} 35 \mathrm{MN}$ & $\mathrm{Fe}-13 \mathrm{Cr}-5 \mathrm{Al}-2 \mathrm{Mo}-1 \mathrm{Nb}$ & 550 & $\begin{array}{c}\text { PTP D7 } \\
5\end{array}$ & $\begin{array}{c}1.08 \mathrm{E}+1 \\
5\end{array}$ & 1 & $2.1 \mathrm{E}+06$ & $2.2 \mathrm{E}+21$ & 1.9 & FCAT04 \\
\hline M607 & SS-J2 & $\mathrm{C} 36 \mathrm{M}$ & $\mathrm{Fe}-13 \mathrm{Cr}-6 \mathrm{Al}-2 \mathrm{Mo}$ & 550 & $\begin{array}{c}\text { PTP D7 } \\
5\end{array}$ & $\begin{array}{c}1.08 \mathrm{E}+1 \\
5\end{array}$ & 1 & $2.1 \mathrm{E}+06$ & $2.2 \mathrm{E}+21$ & 1.9 & FCAT04 \\
\hline M608 & SS-J2 & $\mathrm{C} 36 \mathrm{M}$ & $\mathrm{Fe}-13 \mathrm{Cr}-6 \mathrm{Al}-2 \mathrm{Mo}$ & 550 & $\begin{array}{c}\text { PTP D7 } \\
5\end{array}$ & $\begin{array}{c}1.08 \mathrm{E}+1 \\
5\end{array}$ & 1 & $2.1 \mathrm{E}+06$ & $2.2 \mathrm{E}+21$ & 1.9 & FCAT04 \\
\hline M609 & SS-J2 & $\mathrm{C} 36 \mathrm{M}$ & $\mathrm{Fe}-13 \mathrm{Cr}-6 \mathrm{Al}-2 \mathrm{Mo}$ & 550 & $\begin{array}{c}\text { PTP D7 } \\
5\end{array}$ & $\begin{array}{c}1.08 \mathrm{E}+1 \\
5 \\
\end{array}$ & 1 & $2.1 \mathrm{E}+06$ & $2.2 \mathrm{E}+21$ & 1.9 & FCAT04 \\
\hline MV07 & SS-J2 & $\mathrm{C} 37 \mathrm{M}$ & $\mathrm{Fe}-13 \mathrm{Cr}-7 \mathrm{Al}-2 \mathrm{Mo}$ & 550 & $\begin{array}{c}\text { PTP D7 } \\
5\end{array}$ & $\begin{array}{c}1.08 \mathrm{E}+1 \\
5\end{array}$ & 1 & $2.1 \mathrm{E}+06$ & $2.2 \mathrm{E}+21$ & 1.9 & FCAT04 \\
\hline MV08 & SS-J2 & $\mathrm{C} 37 \mathrm{M}$ & $\mathrm{Fe}-13 \mathrm{Cr}-7 \mathrm{Al}-2 \mathrm{Mo}$ & 550 & $\begin{array}{c}\text { PTP D7 } \\
5 \\
\end{array}$ & $\begin{array}{c}1.08 \mathrm{E}+1 \\
5\end{array}$ & 1 & $2.1 \mathrm{E}+06$ & $2.2 \mathrm{E}+21$ & 1.9 & FCAT04 \\
\hline MV09 & SS-J2 & $\mathrm{C} 37 \mathrm{M}$ & $\mathrm{Fe}-13 \mathrm{Cr}-7 \mathrm{Al}-2 \mathrm{Mo}$ & 550 & $\begin{array}{c}\text { PTP D7 } \\
5\end{array}$ & $\begin{array}{c}1.08 \mathrm{E}+1 \\
5\end{array}$ & 1 & $2.1 \mathrm{E}+06$ & $2.2 \mathrm{E}+21$ & 1.9 & FCAT04 \\
\hline ZM07 & SS-J2 & $\mathrm{C} 06 \mathrm{M}$ & $\mathrm{Fe}-10 \mathrm{Cr}-6 \mathrm{Al}-2 \mathrm{Mo}$ & 550 & $\begin{array}{c}\text { PTP D7 } \\
5\end{array}$ & $\begin{array}{c}1.08 \mathrm{E}+1 \\
5\end{array}$ & 1 & $2.1 \mathrm{E}+06$ & $2.2 \mathrm{E}+21$ & 1.9 & FCAT04 \\
\hline ZM08 & SS-J2 & $\mathrm{C} 06 \mathrm{M}$ & $\mathrm{Fe}-10 \mathrm{Cr}-6 \mathrm{Al}-2 \mathrm{Mo}$ & 550 & $\begin{array}{c}\text { PTP D7 } \\
5\end{array}$ & $\begin{array}{c}1.08 \mathrm{E}+1 \\
5\end{array}$ & 1 & $2.1 \mathrm{E}+06$ & $2.2 \mathrm{E}+21$ & 1.9 & FCAT04 \\
\hline ZM09 & SS-J2 & $\mathrm{C} 06 \mathrm{M}$ & $\mathrm{Fe}-10 \mathrm{Cr}-6 \mathrm{Al}-2 \mathrm{Mo}$ & 550 & $\begin{array}{c}\text { PTP D7 } \\
5\end{array}$ & $\begin{array}{c}1.08 \mathrm{E}+1 \\
5\end{array}$ & 1 & $2.1 \mathrm{E}+06$ & $2.2 \mathrm{E}+21$ & 1.9 & FCAT04 \\
\hline OD05 & SS-J2 & 125YF-ODS & Fe-12Cr-5Al-O-Y & 550 & $\begin{array}{c}\text { PTP D7 } \\
5 \\
\end{array}$ & $\begin{array}{c}1.08 \mathrm{E}+1 \\
5\end{array}$ & 1 & $2.1 \mathrm{E}+06$ & $2.2 \mathrm{E}+21$ & 1.9 & FCAT04 \\
\hline OD06 & SS-J2 & $125 \mathrm{YF}-\mathrm{ODS}$ & Fe-12Cr-5Al-O-Y & 550 & $\begin{array}{c}\text { PTP D7 } \\
5\end{array}$ & $\begin{array}{c}1.08 \mathrm{E}+1 \\
5\end{array}$ & 1 & $2.1 \mathrm{E}+06$ & $2.2 \mathrm{E}+21$ & 1.9 & FCAT04 \\
\hline $\mathrm{TC} 07$ & SS-J2 & $\mathrm{C} 35 \mathrm{MTC} 03$ & $\begin{array}{c}\text { Fe-13Cr-5Al-2Mo- } \\
0.3 \mathrm{TiC}\end{array}$ & 550 & $\begin{array}{c}\text { PTP D7 } \\
5\end{array}$ & $\begin{array}{c}1.08 \mathrm{E}+1 \\
5\end{array}$ & 1 & $2.1 \mathrm{E}+06$ & $2.2 \mathrm{E}+21$ & 1.9 & FCAT04 \\
\hline TC08 & SS-J2 & $\mathrm{C} 35 \mathrm{MTC} 03$ & $\begin{array}{c}\mathrm{Fe}-13 \mathrm{Cr}-5 \mathrm{Al}-2 \mathrm{Mo}- \\
0.3 \mathrm{TiC}\end{array}$ & 550 & $\begin{array}{c}\text { PTP D7 } \\
5\end{array}$ & $\begin{array}{c}1.08 \mathrm{E}+1 \\
5\end{array}$ & 1 & $2.1 \mathrm{E}+06$ & $2.2 \mathrm{E}+21$ & 1.9 & FCAT04 \\
\hline TC09 & SS-J2 & $\mathrm{C} 35 \mathrm{MTC} 03$ & $\begin{array}{c}\text { Fe-13Cr-5Al-2Mo- } \\
0.3 \mathrm{TiC} \\
\end{array}$ & 550 & $\begin{array}{c}\text { PTP D7 } \\
5 \\
\end{array}$ & $\begin{array}{c}1.08 \mathrm{E}+1 \\
5 \\
\end{array}$ & 1 & $2.1 \mathrm{E}+06$ & $2.2 \mathrm{E}+21$ & 1.9 & FCAT04 \\
\hline 5W05 & SS-J2 & C35M-Welded & $\mathrm{Fe}-13 \mathrm{Cr}-5 \mathrm{Al}-2 \mathrm{Mo}$ & 550 & $\begin{array}{c}\text { PTP D7 } \\
5\end{array}$ & $\begin{array}{c}1.08 \mathrm{E}+1 \\
5 \\
\end{array}$ & 1 & $2.1 \mathrm{E}+06$ & $2.2 \mathrm{E}+21$ & 1.9 & FCAT04 \\
\hline 5W06 & SS-J2 & C35M-Welded & $\mathrm{Fe}-13 \mathrm{Cr}-5 \mathrm{Al}-2 \mathrm{Mo}$ & 550 & $\begin{array}{c}\text { PTP D7 } \\
5\end{array}$ & $\begin{array}{c}1.08 \mathrm{E}+1 \\
5\end{array}$ & 1 & $2.1 \mathrm{E}+06$ & $2.2 \mathrm{E}+21$ & 1.9 & FCAT04 \\
\hline NW05 & SS-J2 & C35MN-Welded & $\mathrm{Fe}-13 \mathrm{Cr}-5 \mathrm{Al}-2 \mathrm{Mo}-1 \mathrm{Nb}$ & 550 & $\begin{array}{c}\text { PTP D7 } \\
5\end{array}$ & $\begin{array}{c}1.08 \mathrm{E}+1 \\
5\end{array}$ & 1 & $2.1 \mathrm{E}+06$ & $2.2 \mathrm{E}+21$ & 1.9 & FCAT04 \\
\hline NW06 & SS-J2 & C35MN-Welded & $\mathrm{Fe}-13 \mathrm{Cr}-5 \mathrm{Al}-2 \mathrm{Mo}-1 \mathrm{Nb}$ & 550 & $\begin{array}{c}\text { PTP D7 } \\
5\end{array}$ & $\begin{array}{c}1.08 \mathrm{E}+1 \\
5\end{array}$ & 1 & $2.1 \mathrm{E}+06$ & $2.2 \mathrm{E}+21$ & 1.9 & FCAT04 \\
\hline TW05 & SS-J2 & $\begin{array}{l}\text { C35MTC03- } \\
\text { Welded }\end{array}$ & $\begin{array}{c}\text { Fe-13Cr-5Al-2Mo- } \\
0.3 \mathrm{TiC} \\
\end{array}$ & 550 & $\begin{array}{c}\text { PTP D7 } \\
5\end{array}$ & $\begin{array}{c}1.08 \mathrm{E}+1 \\
5 \\
\end{array}$ & 1 & $2.1 \mathrm{E}+06$ & $2.2 \mathrm{E}+21$ & 1.9 & FCAT04 \\
\hline TW06 & SS-J2 & $\begin{array}{l}\text { C35MTC03- } \\
\text { Welded }\end{array}$ & $\begin{array}{c}\mathrm{Fe}-13 \mathrm{Cr}-5 \mathrm{Al}-2 \mathrm{Mo}- \\
0.3 \mathrm{TiC} \\
\end{array}$ & 550 & $\begin{array}{c}\text { PTP D7 } \\
5\end{array}$ & $\begin{array}{c}1.08 \mathrm{E}+1 \\
5\end{array}$ & 1 & $2.1 \mathrm{E}+06$ & $2.2 \mathrm{E}+21$ & 1.9 & FCAT04 \\
\hline VW05 & SS-J2 & C37M-Welded & $\mathrm{Fe}-13 \mathrm{Cr}-7 \mathrm{Al}-2 \mathrm{Mo}$ & 550 & $\begin{array}{c}\text { PTP D7 } \\
5\end{array}$ & $\begin{array}{c}1.08 \mathrm{E}+1 \\
5\end{array}$ & 1 & $2.1 \mathrm{E}+06$ & $2.2 \mathrm{E}+21$ & 1.9 & FCAT04 \\
\hline VW06 & SS-J2 & C37M-Welded & $\mathrm{Fe}-13 \mathrm{Cr}-7 \mathrm{Al}-2 \mathrm{Mo}$ & 550 & $\begin{array}{c}\text { PTP D7 } \\
5 \\
\end{array}$ & $\begin{array}{c}1.08 \mathrm{E}+1 \\
5 \\
\end{array}$ & 1 & $2.1 \mathrm{E}+06$ & $2.2 \mathrm{E}+21$ & 1.9 & FCAT04 \\
\hline F05 & SS-2E & $\mathrm{C} 35 \mathrm{M}$ & $\mathrm{Fe}-13 \mathrm{Cr}-5 \mathrm{Al}-2 \mathrm{Mo}$ & 550 & $\begin{array}{c}\text { PTP D7 } \\
5\end{array}$ & $\begin{array}{c}1.08 \mathrm{E}+1 \\
5\end{array}$ & 1 & $2.1 \mathrm{E}+06$ & $2.2 \mathrm{E}+21$ & 1.9 & FCAT04 \\
\hline F06 & SS-2E & $\mathrm{C} 35 \mathrm{M}$ & $\mathrm{Fe}-13 \mathrm{Cr}-5 \mathrm{Al}-2 \mathrm{Mo}$ & 550 & $\begin{array}{c}\text { PTP D7 } \\
5\end{array}$ & $\begin{array}{c}1.08 \mathrm{E}+1 \\
5\end{array}$ & 1 & $2.1 \mathrm{E}+06$ & $2.2 \mathrm{E}+21$ & 1.9 & FCAT04 \\
\hline N05 & SS-2E & $\mathrm{C} 35 \mathrm{MN}$ & $\mathrm{Fe}-13 \mathrm{Cr}-5 \mathrm{Al}-2 \mathrm{Mo}-1 \mathrm{Nb}$ & 550 & $\begin{array}{c}\text { PTP D7 } \\
5\end{array}$ & $\begin{array}{c}1.08 \mathrm{E}+1 \\
5\end{array}$ & 1 & $2.1 \mathrm{E}+06$ & $2.2 \mathrm{E}+21$ & 1.9 & FCAT04 \\
\hline N06 & SS-2E & $\mathrm{C} 35 \mathrm{MN}$ & $\mathrm{Fe}-13 \mathrm{Cr}-5 \mathrm{Al}-2 \mathrm{Mo}-1 \mathrm{Nb}$ & 550 & $\begin{array}{c}\text { PTP D7 } \\
5 \\
\end{array}$ & $\begin{array}{c}1.08 \mathrm{E}+1 \\
5 \\
\end{array}$ & 1 & $2.1 \mathrm{E}+06$ & $2.2 \mathrm{E}+21$ & 1.9 & FCAT04 \\
\hline V05 & SS-2E & $\mathrm{C} 37 \mathrm{M}$ & $\mathrm{Fe}-13 \mathrm{Cr}-7 \mathrm{Al}-2 \mathrm{Mo}$ & 550 & $\begin{array}{c}\text { PTP D7 } \\
5\end{array}$ & $\begin{array}{c}1.08 \mathrm{E}+1 \\
5 \\
\end{array}$ & 1 & $2.1 \mathrm{E}+06$ & $2.2 \mathrm{E}+21$ & 1.9 & FCAT04 \\
\hline V06 & SS-2E & $\mathrm{C} 37 \mathrm{M}$ & $\mathrm{Fe}-13 \mathrm{Cr}-7 \mathrm{Al}-2 \mathrm{Mo}$ & 550 & $\begin{array}{c}\text { PTP D7 } \\
5 \\
\end{array}$ & $\begin{array}{c}1.08 \mathrm{E}+1 \\
5\end{array}$ & 1 & $2.1 \mathrm{E}+06$ & $2.2 \mathrm{E}+21$ & 1.9 & FCAT04 \\
\hline T05 & SS-2E & C35MTC03 & $\begin{array}{c}\mathrm{Fe}-13 \mathrm{Cr}-5 \mathrm{Al}-2 \mathrm{Mo}- \\
0.3 \mathrm{TiC} \\
\end{array}$ & 550 & $\begin{array}{c}\text { PTP D7 } \\
5\end{array}$ & $\begin{array}{c}1.08 \mathrm{E}+1 \\
5\end{array}$ & 1 & $2.1 \mathrm{E}+06$ & $2.2 \mathrm{E}+21$ & 1.9 & FCAT04 \\
\hline T06 & SS-2E & C35MTC03 & $\begin{array}{c}\mathrm{Fe}-13 \mathrm{Cr}-5 \mathrm{Al}-2 \mathrm{Mo}- \\
0.3 \mathrm{TiC} \\
\end{array}$ & 550 & $\begin{array}{c}\text { PTP D7 } \\
5\end{array}$ & $\begin{array}{c}1.08 \mathrm{E}+1 \\
5\end{array}$ & 1 & $2.1 \mathrm{E}+06$ & $2.2 \mathrm{E}+21$ & 1.9 & FCAT04 \\
\hline $\mathrm{A} 05$ & SS-2E & C35M-Welded & $\mathrm{Fe}-13 \mathrm{Cr}-5 \mathrm{Al}-2 \mathrm{Mo}$ & 550 & $\begin{array}{c}\text { PTP D7 } \\
5\end{array}$ & $\begin{array}{c}1.08 \mathrm{E}+1 \\
5 \\
\end{array}$ & 1 & $2.1 \mathrm{E}+06$ & $2.2 \mathrm{E}+21$ & 1.9 & FCAT04 \\
\hline
\end{tabular}




\begin{tabular}{|c|c|c|c|c|c|c|c|c|c|c|c|}
\hline A06 & SS-2E & C35M-Welded & $\mathrm{Fe}-13 \mathrm{Cr}-5 \mathrm{Al}-2 \mathrm{Mo}$ & 550 & $\begin{array}{l}\text { PTP D7 } \\
5\end{array}$ & $\begin{array}{c}1.08 \mathrm{E}+1 \\
5\end{array}$ & 1 & $2.1 \mathrm{E}+06$ & $2.2 \mathrm{E}+21$ & 1.9 & FCAT04 \\
\hline $\mathrm{B} 05$ & SS-2E & C35MN-Welded & $\mathrm{Fe}-13 \mathrm{Cr}-5 \mathrm{Al}-2 \mathrm{Mo}-1 \mathrm{Nb}$ & 550 & $\begin{array}{c}\text { PTP D7 } \\
5 \\
\end{array}$ & $\begin{array}{c}1.08 \mathrm{E}+1 \\
5\end{array}$ & 1 & $2.1 \mathrm{E}+06$ & $2.2 \mathrm{E}+21$ & 1.9 & FCAT04 \\
\hline B06 & SS-2E & C35MN-Welded & $\mathrm{Fe}-13 \mathrm{Cr}-5 \mathrm{Al}-2 \mathrm{Mo}-1 \mathrm{Nb}$ & 550 & $\begin{array}{c}\text { PTP D7 } \\
5 \\
\end{array}$ & $\begin{array}{c}1.08 \mathrm{E}+1 \\
5\end{array}$ & 1 & $2.1 \mathrm{E}+06$ & $2.2 \mathrm{E}+21$ & 1.9 & FCAT04 \\
\hline $\mathrm{C} 07$ & SS-2E & $\begin{array}{l}\text { C35MTC03- } \\
\text { Welded }\end{array}$ & $\begin{array}{c}\mathrm{Fe}-13 \mathrm{Cr}-5 \mathrm{Al}-2 \mathrm{Mo}- \\
0.3 \mathrm{TiC} \\
\end{array}$ & 550 & $\begin{array}{c}\text { PTP D7 } \\
5\end{array}$ & $\begin{array}{c}1.08 \mathrm{E}+1 \\
5\end{array}$ & 1 & $2.1 \mathrm{E}+06$ & $2.2 \mathrm{E}+21$ & 1.9 & FCAT04 \\
\hline $\mathrm{C} 08$ & SS-2E & $\begin{array}{l}\text { C35MTC03- } \\
\text { Welded }\end{array}$ & $\begin{array}{c}\text { Fe-13Cr-5Al-2Mo- } \\
0.3 \mathrm{TiC}\end{array}$ & 550 & $\begin{array}{c}\text { PTP D7 } \\
5\end{array}$ & $\begin{array}{c}1.08 \mathrm{E}+1 \\
5\end{array}$ & 1 & $2.1 \mathrm{E}+06$ & $2.2 \mathrm{E}+21$ & 1.9 & FCAT04 \\
\hline $\mathrm{C} 09$ & SS-2E & $\begin{array}{l}\text { C35MTC03- } \\
\text { Welded }\end{array}$ & $\begin{array}{c}\text { Fe-13Cr-5Al-2Mo- } \\
0.3 \mathrm{TiC} \\
\end{array}$ & 550 & $\begin{array}{c}\text { PTP D7 } \\
5\end{array}$ & $\begin{array}{c}1.08 \mathrm{E}+1 \\
5 \\
\end{array}$ & 1 & $2.1 \mathrm{E}+06$ & $2.2 \mathrm{E}+21$ & 1.9 & FCAT04 \\
\hline S07 & SS-2E & C37M-Welded & Fe-13Cr-7Al-2Mo & 550 & $\begin{array}{c}\text { PTP D7 } \\
5\end{array}$ & $\begin{array}{c}1.08 \mathrm{E}+1 \\
5 \\
\end{array}$ & 1 & $2.1 \mathrm{E}+06$ & $2.2 \mathrm{E}+21$ & 1.9 & FCAT04 \\
\hline $\mathrm{S} 08$ & SS-2E & C37M-Welded & $\mathrm{Fe}-13 \mathrm{Cr}-7 \mathrm{Al}-2 \mathrm{Mo}$ & 550 & $\begin{array}{c}\text { PTP D7 } \\
5\end{array}$ & $\begin{array}{c}1.08 \mathrm{E}+1 \\
5\end{array}$ & 1 & $2.1 \mathrm{E}+06$ & $2.2 \mathrm{E}+21$ & 1.9 & FCAT04 \\
\hline S09 & SS-2E & C37M-Welded & $\mathrm{Fe}-13 \mathrm{Cr}-7 \mathrm{Al}-2 \mathrm{Mo}$ & 550 & $\begin{array}{c}\text { PTP D7 } \\
5\end{array}$ & $\begin{array}{c}1.08 \mathrm{E}+1 \\
5\end{array}$ & 1 & $2.1 \mathrm{E}+06$ & $2.2 \mathrm{E}+21$ & 1.9 & FCAT04 \\
\hline MF16 & SS-J2 & $\mathrm{C} 35 \mathrm{M}$ & $\mathrm{Fe}-13 \mathrm{Cr}-5 \mathrm{Al}-2 \mathrm{Mo}$ & 550 & $\begin{array}{c}\text { PTP G4 } \\
5\end{array}$ & $\begin{array}{c}1.08 \mathrm{E}+1 \\
5\end{array}$ & 4 & $8.3 \mathrm{E}+06$ & $9.0 \mathrm{E}+21$ & 7.4 & FCAT05 \\
\hline MF 17 & SS-J2 & $\mathrm{C} 35 \mathrm{M}$ & $\mathrm{Fe}-13 \mathrm{Cr}-5 \mathrm{Al}-2 \mathrm{Mo}$ & 550 & $\begin{array}{c}\text { PTP G4 } \\
5 \\
\end{array}$ & $\begin{array}{c}1.08 \mathrm{E}+1 \\
5\end{array}$ & 4 & $8.3 \mathrm{E}+06$ & $9.0 \mathrm{E}+21$ & 7.4 & FCAT05 \\
\hline MF18 & SS-J2 & $\mathrm{C} 35 \mathrm{M}$ & $\mathrm{Fe}-13 \mathrm{Cr}-5 \mathrm{Al}-2 \mathrm{Mo}$ & 550 & $\begin{array}{c}\text { PTP G4 } \\
5 \\
\end{array}$ & $\begin{array}{c}1.08 \mathrm{E}+1 \\
5\end{array}$ & 4 & $8.3 \mathrm{E}+06$ & $9.0 \mathrm{E}+21$ & 7.4 & FCAT05 \\
\hline N511 & SS-J2 & $\mathrm{C} 35 \mathrm{MN}$ & $\mathrm{Fe}-13 \mathrm{Cr}-5 \mathrm{Al}-2 \mathrm{Mo}-1 \mathrm{Nb}$ & 550 & $\begin{array}{c}\text { PTP G4 } \\
5 \\
\end{array}$ & $\begin{array}{c}1.08 \mathrm{E}+1 \\
5 \\
\end{array}$ & 4 & $8.3 \mathrm{E}+06$ & $9.0 \mathrm{E}+21$ & 7.4 & FCAT05 \\
\hline N512 & SS-J2 & $\mathrm{C} 35 \mathrm{MN}$ & $\mathrm{Fe}-13 \mathrm{Cr}-5 \mathrm{Al}-2 \mathrm{Mo}-1 \mathrm{Nb}$ & 550 & $\begin{array}{c}\text { PTP G4 } \\
\quad 5 \\
\end{array}$ & $\begin{array}{c}1.08 \mathrm{E}+1 \\
5\end{array}$ & 4 & $8.3 \mathrm{E}+06$ & $9.0 \mathrm{E}+21$ & 7.4 & FCAT05 \\
\hline M616 & SS-J2 & $\mathrm{C} 36 \mathrm{M}$ & $\mathrm{Fe}-13 \mathrm{Cr}-6 \mathrm{Al}-2 \mathrm{Mo}$ & 550 & $\begin{array}{c}\text { PTP G4 } \\
5 \\
\end{array}$ & $\begin{array}{c}1.08 \mathrm{E}+1 \\
5 \\
\end{array}$ & 4 & $8.3 \mathrm{E}+06$ & $9.0 \mathrm{E}+21$ & 7.4 & FCAT05 \\
\hline M617 & SS-J2 & $\mathrm{C} 36 \mathrm{M}$ & $\mathrm{Fe}-13 \mathrm{Cr}-6 \mathrm{Al}-2 \mathrm{Mo}$ & 550 & $\begin{array}{c}\text { PTP G4 } \\
5 \\
\end{array}$ & $\begin{array}{c}1.08 \mathrm{E}+1 \\
5 \\
\end{array}$ & 4 & $8.3 \mathrm{E}+06$ & $9.0 \mathrm{E}+21$ & 7.4 & FCAT05 \\
\hline M618 & SS-J2 & $\mathrm{C} 36 \mathrm{M}$ & $\mathrm{Fe}-13 \mathrm{Cr}-6 \mathrm{Al}-2 \mathrm{Mo}$ & 550 & $\begin{array}{c}\text { PTP G4 } \\
5 \\
\end{array}$ & $\begin{array}{c}1.08 \mathrm{E}+1 \\
5 \\
\end{array}$ & 4 & $8.3 \mathrm{E}+06$ & $9.0 \mathrm{E}+21$ & 7.4 & FCAT05 \\
\hline MV16 & SS-J2 & $\mathrm{C} 37 \mathrm{M}$ & $\mathrm{Fe}-13 \mathrm{Cr}-7 \mathrm{Al}-2 \mathrm{Mo}$ & 550 & $\begin{array}{c}\text { PTP G4 } \\
5 \\
\end{array}$ & $\begin{array}{c}1.08 \mathrm{E}+1 \\
5\end{array}$ & 4 & $8.3 \mathrm{E}+06$ & $9.0 \mathrm{E}+21$ & 7.4 & FCAT05 \\
\hline MV17 & SS-J2 & $\mathrm{C} 37 \mathrm{M}$ & $\mathrm{Fe}-13 \mathrm{Cr}-7 \mathrm{Al}-2 \mathrm{Mo}$ & 550 & $\begin{array}{c}\text { PTP G4 } \\
5 \\
\end{array}$ & $\begin{array}{c}1.08 \mathrm{E}+1 \\
5 \\
\end{array}$ & 4 & $8.3 \mathrm{E}+06$ & $9.0 \mathrm{E}+21$ & 7.4 & FCAT05 \\
\hline MV18 & SS-J2 & $\mathrm{C} 37 \mathrm{M}$ & $\mathrm{Fe}-13 \mathrm{Cr}-7 \mathrm{Al}-2 \mathrm{Mo}$ & 550 & $\begin{array}{c}\text { PTP G4 } \\
5 \\
\end{array}$ & $\begin{array}{c}1.08 \mathrm{E}+1 \\
5 \\
\end{array}$ & 4 & $8.3 \mathrm{E}+06$ & $9.0 \mathrm{E}+21$ & 7.4 & FCAT05 \\
\hline ZM16 & SS-J2 & $\mathrm{C} 06 \mathrm{M}$ & $\mathrm{Fe}-10 \mathrm{Cr}-6 \mathrm{Al}-2 \mathrm{Mo}$ & 550 & $\begin{array}{c}\text { PTP G4 } \\
5 \\
\end{array}$ & $\begin{array}{c}1.08 \mathrm{E}+1 \\
5\end{array}$ & 4 & $8.3 \mathrm{E}+06$ & $9.0 \mathrm{E}+21$ & 7.4 & FCAT05 \\
\hline ZM17 & SS-J2 & $\mathrm{C} 06 \mathrm{M}$ & Fe-10Cr-6Al-2Mo & 550 & $\begin{array}{c}\text { PTP G4 } \\
5\end{array}$ & $\begin{array}{c}1.08 \mathrm{E}+1 \\
5\end{array}$ & 4 & $8.3 \mathrm{E}+06$ & $9.0 \mathrm{E}+21$ & 7.4 & FCAT05 \\
\hline ZM18 & SS-J2 & $\mathrm{C} 06 \mathrm{M}$ & $\mathrm{Fe}-10 \mathrm{Cr}-6 \mathrm{Al}-2 \mathrm{Mo}$ & 550 & $\begin{array}{c}\text { PTP G4 } \\
5\end{array}$ & $\begin{array}{c}1.08 \mathrm{E}+1 \\
5\end{array}$ & 4 & $8.3 \mathrm{E}+06$ & $9.0 \mathrm{E}+21$ & 7.4 & FCAT05 \\
\hline OD11 & SS-J2 & 125YF-ODS & $\mathrm{Fe}-12 \mathrm{Cr}-5 \mathrm{Al}-\mathrm{O}-\mathrm{Y}$ & 550 & $\begin{array}{c}\text { PTP G4 } \\
5 \\
\end{array}$ & $\begin{array}{c}1.08 \mathrm{E}+1 \\
5 \\
\end{array}$ & 4 & $8.3 \mathrm{E}+06$ & $9.0 \mathrm{E}+21$ & 7.4 & FCAT05 \\
\hline OD12 & SS-J2 & 125YF-ODS & $\mathrm{Fe}-12 \mathrm{Cr}-5 \mathrm{Al}-\mathrm{O}-\mathrm{Y}$ & 550 & $\begin{array}{c}\text { PTP G4 } \\
5 \\
\end{array}$ & $\begin{array}{c}1.08 \mathrm{E}+1 \\
5 \\
\end{array}$ & 4 & $8.3 \mathrm{E}+06$ & $9.0 \mathrm{E}+21$ & 7.4 & FCAT05 \\
\hline $\mathrm{TC} 16$ & SS-J2 & $\mathrm{C} 35 \mathrm{M}+\mathrm{TC} 03$ & $\begin{array}{c}\mathrm{Fe}-13 \mathrm{Cr}-5 \mathrm{Al}-2 \mathrm{Mo}- \\
0.3 \mathrm{TiC} \\
\end{array}$ & 550 & $\begin{array}{c}\text { PTP G4 } \\
5\end{array}$ & $\begin{array}{c}1.08 \mathrm{E}+1 \\
5\end{array}$ & 4 & $8.3 \mathrm{E}+06$ & $9.0 \mathrm{E}+21$ & 7.4 & FCAT05 \\
\hline $\mathrm{TC} 17$ & SS-J2 & C35MTC03 & $\begin{array}{c}\mathrm{Fe}-13 \mathrm{Cr}-5 \mathrm{Al}-2 \mathrm{Mo}- \\
0.3 \mathrm{TiC} \\
\end{array}$ & 550 & $\begin{array}{c}\text { PTP G4 } \\
5\end{array}$ & $\begin{array}{c}1.08 \mathrm{E}+1 \\
5\end{array}$ & 4 & $8.3 \mathrm{E}+06$ & $9.0 \mathrm{E}+21$ & 7.4 & FCAT05 \\
\hline $\mathrm{TC} 18$ & SS-J2 & C35MTC03 & $\begin{array}{c}\text { Fe-13Cr-5Al-2Mo- } \\
0.3 \mathrm{TiC} \\
\end{array}$ & 550 & $\begin{array}{c}\text { PTP G4 } \\
5 \\
\end{array}$ & $\begin{array}{c}1.08 \mathrm{E}+1 \\
5 \\
\end{array}$ & 4 & $8.3 \mathrm{E}+06$ & $9.0 \mathrm{E}+21$ & 7.4 & FCAT05 \\
\hline $5 \mathrm{~W} 11$ & SS-J2 & C35M-Welded & Fe-13Cr-5Al-2Mo & 550 & $\begin{array}{c}\text { PTP G4 } \\
5 \\
\end{array}$ & $\begin{array}{c}1.08 \mathrm{E}+1 \\
5\end{array}$ & 4 & $8.3 \mathrm{E}+06$ & $9.0 \mathrm{E}+21$ & 7.4 & FCAT05 \\
\hline $5 \mathrm{~W} 12$ & SS-J2 & C35M-Welded & $\mathrm{Fe}-13 \mathrm{Cr}-5 \mathrm{Al}-2 \mathrm{Mo}$ & 550 & $\begin{array}{c}\text { PTP G4 } \\
5\end{array}$ & $\begin{array}{c}1.08 \mathrm{E}+1 \\
5\end{array}$ & 4 & $8.3 \mathrm{E}+06$ & $9.0 \mathrm{E}+21$ & 7.4 & FCAT05 \\
\hline NW11 & SS-J2 & C35MN-Welded & $\mathrm{Fe}-13 \mathrm{Cr}-5 \mathrm{Al}-2 \mathrm{Mo}-1 \mathrm{Nb}$ & 550 & $\begin{array}{l}\text { PTP G4 } \\
5\end{array}$ & $\begin{array}{c}1.08 \mathrm{E}+1 \\
5\end{array}$ & 4 & $8.3 \mathrm{E}+06$ & $9.0 \mathrm{E}+21$ & 7.4 & FCAT05 \\
\hline NW12 & SS-J2 & C35MN-Welded & $\mathrm{Fe}-13 \mathrm{Cr}-5 \mathrm{Al}-2 \mathrm{Mo}-1 \mathrm{Nb}$ & 550 & $\begin{array}{c}\text { PTP G4 } \\
5 \\
\end{array}$ & $\begin{array}{c}1.08 \mathrm{E}+1 \\
5\end{array}$ & 4 & $8.3 \mathrm{E}+06$ & $9.0 \mathrm{E}+21$ & 7.4 & FCAT05 \\
\hline TW11 & SS-J2 & $\begin{array}{l}\text { C35MTC03- } \\
\text { Welded }\end{array}$ & $\begin{array}{c}\text { Fe-13Cr-5Al-2Mo- } \\
0.3 \mathrm{TiC} \\
\end{array}$ & 550 & $\begin{array}{c}\text { PTP G4 } \\
5 \\
\end{array}$ & $\begin{array}{c}1.08 \mathrm{E}+1 \\
5\end{array}$ & 4 & $8.3 \mathrm{E}+06$ & $9.0 \mathrm{E}+21$ & 7.4 & FCAT05 \\
\hline TW12 & SS-J2 & $\begin{array}{l}\text { C35MTC03- } \\
\text { Welded }\end{array}$ & $\begin{array}{c}\mathrm{Fe}-13 \mathrm{Cr}-5 \mathrm{Al}-2 \mathrm{Mo}- \\
0.3 \mathrm{TiC} \\
\end{array}$ & 550 & $\begin{array}{c}\text { PTP G4 } \\
5 \\
\end{array}$ & $\begin{array}{c}1.08 \mathrm{E}+1 \\
5\end{array}$ & 4 & $8.3 \mathrm{E}+06$ & $9.0 \mathrm{E}+21$ & 7.4 & FCAT05 \\
\hline VW11 & SS-J2 & C37M-Welded & $\mathrm{Fe}-13 \mathrm{Cr}-7 \mathrm{Al}-2 \mathrm{Mo}$ & 550 & $\begin{array}{c}\text { PTP G4 } \\
5\end{array}$ & $\begin{array}{c}1.08 \mathrm{E}+1 \\
5\end{array}$ & 4 & $8.3 \mathrm{E}+06$ & $9.0 \mathrm{E}+21$ & 7.4 & FCAT05 \\
\hline VW12 & SS-J2 & C37M-Welded & $\mathrm{Fe}-13 \mathrm{Cr}-7 \mathrm{Al}-2 \mathrm{Mo}$ & 550 & $\begin{array}{c}\text { PTP G4 } \\
5 \\
\end{array}$ & $\begin{array}{c}1.08 \mathrm{E}+1 \\
5 \\
\end{array}$ & 4 & $8.3 \mathrm{E}+06$ & $9.0 \mathrm{E}+21$ & 7.4 & FCAT05 \\
\hline $\mathrm{F} 11$ & SS-2E & $\mathrm{C} 35 \mathrm{M}$ & $\mathrm{Fe}-13 \mathrm{Cr}-5 \mathrm{Al}-2 \mathrm{Mo}$ & 550 & $\begin{array}{c}\text { PTP G4 } \\
5 \\
\end{array}$ & $\begin{array}{c}1.08 \mathrm{E}+1 \\
5 \\
\end{array}$ & 4 & $8.3 \mathrm{E}+06$ & $9.0 \mathrm{E}+21$ & 7.4 & FCAT05 \\
\hline $\mathrm{F} 12$ & SS-2E & $\mathrm{C} 35 \mathrm{M}$ & $\mathrm{Fe}-13 \mathrm{Cr}-5 \mathrm{Al}-2 \mathrm{Mo}$ & 550 & $\begin{array}{c}\text { PTP G4 } \\
5 \\
\end{array}$ & $\begin{array}{c}1.08 \mathrm{E}+1 \\
5\end{array}$ & 4 & $8.3 \mathrm{E}+06$ & $9.0 \mathrm{E}+21$ & 7.4 & FCAT05 \\
\hline N11 & SS-2E & $\mathrm{C} 35 \mathrm{MN}$ & $\mathrm{Fe}-13 \mathrm{Cr}-5 \mathrm{Al}-2 \mathrm{Mo}-1 \mathrm{Nb}$ & 550 & $\begin{array}{c}\text { PTP G4 } \\
5\end{array}$ & $\begin{array}{c}1.08 \mathrm{E}+1 \\
5\end{array}$ & 4 & $8.3 \mathrm{E}+06$ & $9.0 \mathrm{E}+21$ & 7.4 & FCAT05 \\
\hline $\mathrm{N} 12$ & SS-2E & $\mathrm{C} 35 \mathrm{MN}$ & $\mathrm{Fe}-13 \mathrm{Cr}-5 \mathrm{Al}-2 \mathrm{Mo}-1 \mathrm{Nb}$ & 550 & $\begin{array}{c}\text { PTP G4 } \\
5 \\
\end{array}$ & $\begin{array}{c}1.08 \mathrm{E}+1 \\
5\end{array}$ & 4 & $8.3 \mathrm{E}+06$ & $9.0 \mathrm{E}+21$ & 7.4 & FCAT05 \\
\hline V11 & SS-2E & $\mathrm{C} 37 \mathrm{M}$ & $\mathrm{Fe}-13 \mathrm{Cr}-7 \mathrm{Al}-2 \mathrm{Mo}$ & 550 & $\begin{array}{c}\text { PTP G4 } \\
5 \\
\end{array}$ & $\begin{array}{c}1.08 \mathrm{E}+1 \\
5\end{array}$ & 4 & $8.3 \mathrm{E}+06$ & $9.0 \mathrm{E}+21$ & 7.4 & FCAT05 \\
\hline
\end{tabular}




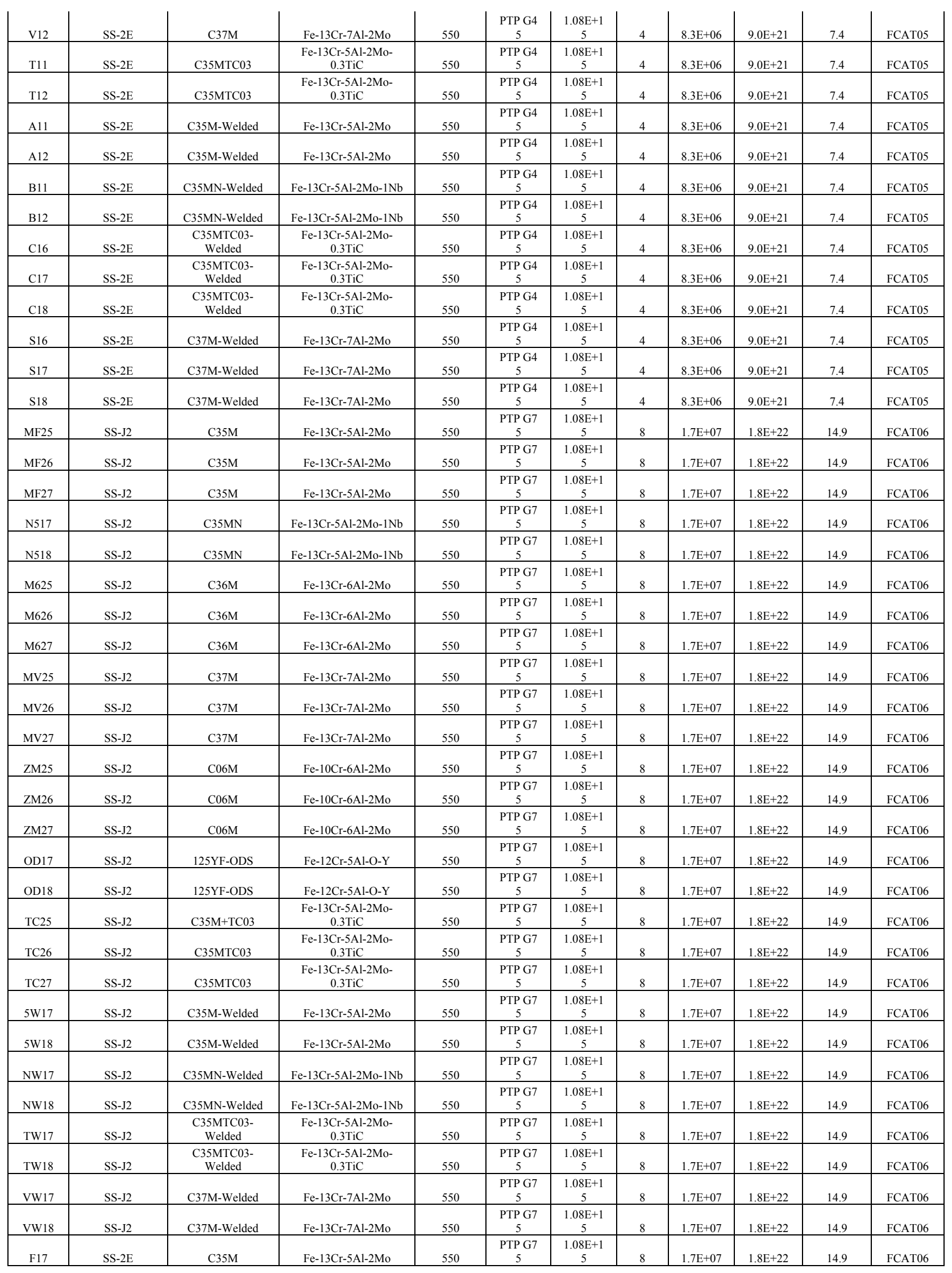




\begin{tabular}{|c|c|c|c|c|c|c|c|c|c|c|c|}
\hline F18 & SS-2E & $\mathrm{C} 35 \mathrm{M}$ & $\mathrm{Fe}-13 \mathrm{Cr}-5 \mathrm{Al}-2 \mathrm{Mo}$ & 550 & $\begin{array}{c}\text { PTP G7 } \\
5\end{array}$ & $\begin{array}{c}1.08 \mathrm{E}+1 \\
5\end{array}$ & 8 & $1.7 \mathrm{E}+07$ & $1.8 \mathrm{E}+22$ & 14.9 & FCAT06 \\
\hline N17 & SS-2E & $\mathrm{C} 35 \mathrm{MN}$ & Fe-13Cr-5Al-2Mo-1Nb & 550 & $\begin{array}{c}\text { PTP G7 } \\
5 \\
\end{array}$ & $\begin{array}{c}1.08 \mathrm{E}+1 \\
5 \\
\end{array}$ & 8 & $1.7 \mathrm{E}+07$ & $1.8 \mathrm{E}+22$ & 14.9 & FCAT06 \\
\hline N18 & SS-2E & $\mathrm{C} 35 \mathrm{MN}$ & $\mathrm{Fe}-13 \mathrm{Cr}-5 \mathrm{Al}-2 \mathrm{Mo}-1 \mathrm{Nb}$ & 550 & $\begin{array}{c}\text { PTP G7 } \\
5\end{array}$ & $\begin{array}{c}1.08 \mathrm{E}+1 \\
5\end{array}$ & 8 & $1.7 \mathrm{E}+07$ & $1.8 \mathrm{E}+22$ & 14.9 & FCAT06 \\
\hline V17 & SS-2E & $\mathrm{C} 37 \mathrm{M}$ & $\mathrm{Fe}-13 \mathrm{Cr}-7 \mathrm{Al}-2 \mathrm{Mo}$ & 550 & $\begin{array}{l}\text { PTP G7 } \\
5\end{array}$ & $\begin{array}{c}1.08 \mathrm{E}+1 \\
5\end{array}$ & 8 & $1.7 \mathrm{E}+07$ & $1.8 \mathrm{E}+22$ & 14.9 & FCAT06 \\
\hline V18 & SS-2E & $\mathrm{C} 37 \mathrm{M}$ & $\mathrm{Fe}-13 \mathrm{Cr}-7 \mathrm{Al}-2 \mathrm{Mo}$ & 550 & $\begin{array}{l}\text { PTP G7 } \\
5\end{array}$ & $\begin{array}{c}1.08 \mathrm{E}+1 \\
5\end{array}$ & 8 & $1.7 \mathrm{E}+07$ & $1.8 \mathrm{E}+22$ & 14.9 & FCAT06 \\
\hline $\mathrm{T} 17$ & SS-2E & С35MTC03 & $\begin{array}{c}\mathrm{Fe}-13 \mathrm{Cr}-5 \mathrm{Al}-2 \mathrm{Mo}- \\
0.3 \mathrm{TiC}\end{array}$ & 550 & $\begin{array}{l}\text { PTP G7 } \\
5\end{array}$ & $\begin{array}{c}1.08 \mathrm{E}+1 \\
5\end{array}$ & 8 & $1.7 \mathrm{E}+07$ & $1.8 \mathrm{E}+22$ & 14.9 & FCAT06 \\
\hline $\mathrm{T} 18$ & SS-2E & $\mathrm{C} 35 \mathrm{MTC} 03$ & $\begin{array}{c}\mathrm{Fe}-13 \mathrm{Cr}-5 \mathrm{Al}-2 \mathrm{Mo}- \\
0.3 \mathrm{TiC}\end{array}$ & 550 & $\begin{array}{l}\text { PTP G7 } \\
5\end{array}$ & $\begin{array}{c}1.08 \mathrm{E}+1 \\
5\end{array}$ & 8 & $1.7 \mathrm{E}+07$ & $1.8 \mathrm{E}+22$ & 14.9 & FCAT06 \\
\hline A17 & SS-2E & C35M-Welded & $\mathrm{Fe}-13 \mathrm{Cr}-5 \mathrm{Al}-2 \mathrm{Mo}$ & 550 & $\begin{array}{l}\text { PTP G7 } \\
5\end{array}$ & $\begin{array}{c}1.08 \mathrm{E}+1 \\
5\end{array}$ & 8 & $1.7 \mathrm{E}+07$ & $1.8 \mathrm{E}+22$ & 14.9 & FCAT06 \\
\hline A18 & SS-2E & C35M-Welded & $\mathrm{Fe}-13 \mathrm{Cr}-5 \mathrm{Al}-2 \mathrm{Mo}$ & 550 & $\begin{array}{l}\text { PTP G7 } \\
5\end{array}$ & $\begin{array}{c}1.08 \mathrm{E}+1 \\
5\end{array}$ & 8 & $1.7 \mathrm{E}+07$ & $1.8 \mathrm{E}+22$ & 14.9 & FCAT06 \\
\hline B17 & SS-2E & C35MN-Welded & $\mathrm{Fe}-13 \mathrm{Cr}-5 \mathrm{Al}-2 \mathrm{Mo}-1 \mathrm{Nb}$ & 550 & $\begin{array}{l}\text { PTP G7 } \\
5\end{array}$ & $\begin{array}{c}1.08 \mathrm{E}+1 \\
5\end{array}$ & 8 & $1.7 \mathrm{E}+07$ & $1.8 \mathrm{E}+22$ & 14.9 & FCAT06 \\
\hline B18 & SS-2E & C35MN-Welded & $\mathrm{Fe}-13 \mathrm{Cr}-5 \mathrm{Al}-2 \mathrm{Mo}-1 \mathrm{Nb}$ & 550 & $\begin{array}{l}\text { PTP G7 } \\
5\end{array}$ & $\begin{array}{l}1.08 \mathrm{E}+1 \\
5\end{array}$ & 8 & $1.7 \mathrm{E}+07$ & $1.8 \mathrm{E}+22$ & 14.9 & FCAT06 \\
\hline $\mathrm{C} 25$ & SS-2E & $\begin{array}{l}\text { C35MTC03- } \\
\text { Welded }\end{array}$ & $\begin{array}{c}\mathrm{Fe}-13 \mathrm{Cr}-5 \mathrm{Al}-2 \mathrm{Mo}- \\
0.3 \mathrm{TiC} \\
\end{array}$ & 550 & $\begin{array}{l}\text { PTP G7 } \\
5\end{array}$ & $\begin{array}{c}1.08 \mathrm{E}+1 \\
5\end{array}$ & 8 & $1.7 \mathrm{E}+07$ & $1.8 \mathrm{E}+22$ & 14.9 & FCAT06 \\
\hline $\mathrm{C} 26$ & SS-2E & $\begin{array}{c}\text { C35MTC03- } \\
\text { Welded }\end{array}$ & $\begin{array}{c}\mathrm{Fe}-13 \mathrm{Cr}-5 \mathrm{Al}-2 \mathrm{Mo}- \\
0.3 \mathrm{TiC}\end{array}$ & 550 & $\begin{array}{l}\text { PTP G7 } \\
5\end{array}$ & $\begin{array}{c}1.08 \mathrm{E}+1 \\
5\end{array}$ & 8 & $1.7 \mathrm{E}+07$ & $1.8 \mathrm{E}+22$ & 14.9 & FCAT06 \\
\hline $\mathrm{C} 27$ & SS-2E & $\begin{array}{l}\text { C35MTC03- } \\
\text { Welded }\end{array}$ & $\begin{array}{c}\text { Fe-13Cr-5Al-2Mo- } \\
0.3 \mathrm{TiC}\end{array}$ & 550 & $\begin{array}{l}\text { PTP G7 } \\
\quad 5\end{array}$ & $\begin{array}{c}1.08 \mathrm{E}+1 \\
5\end{array}$ & 8 & $1.7 \mathrm{E}+07$ & $1.8 \mathrm{E}+22$ & 14.9 & FCAT06 \\
\hline S25 & SS-2E & C37M-Welded & $\mathrm{Fe}-13 \mathrm{Cr}-7 \mathrm{Al}-2 \mathrm{Mo}$ & 550 & $\begin{array}{l}\text { PTP G7 } \\
5\end{array}$ & $\begin{array}{c}1.08 \mathrm{E}+1 \\
5\end{array}$ & 8 & $1.7 \mathrm{E}+07$ & $1.8 \mathrm{E}+22$ & 14.9 & FCAT06 \\
\hline S26 & SS-2E & C37M-Welded & $\mathrm{Fe}-13 \mathrm{Cr}-7 \mathrm{Al}-2 \mathrm{Mo}$ & 550 & $\begin{array}{l}\text { PTP G7 } \\
5\end{array}$ & $\begin{array}{c}1.08 \mathrm{E}+1 \\
5\end{array}$ & 8 & $1.7 \mathrm{E}+07$ & $1.8 \mathrm{E}+22$ & 14.9 & FCAT06 \\
\hline S27 & SS-2E & C37M-Welded & $\mathrm{Fe}-13 \mathrm{Cr}-7 \mathrm{Al}-2 \mathrm{Mo}$ & 550 & $\begin{array}{c}\text { PTP G7 } \\
5\end{array}$ & $\begin{array}{c}1.08 \mathrm{E}+1 \\
5\end{array}$ & 8 & $1.7 \mathrm{E}+07$ & $1.8 \mathrm{E}+22$ & 14.9 & FCAT06 \\
\hline
\end{tabular}

